\title{
Zircon U-Pb Ages and Geochemistry of Granite Porphyries in the Yangla Cu Deposit, SW China: Constraints on Petrogenesis and Tectonic Evolution of the Jinshajiang Suture Belt
}

\author{
Bo Li $\mathbb{D}^{1}{ }^{1}$ Xinfu Wang, ${ }^{1}$ Lijuan Du, ${ }^{2}$ Zuopeng Xiang, ${ }^{1}$ Guo Tang, ${ }^{1}$ and Zhilong Huang ${ }^{3}$ \\ ${ }^{1}$ Faculty of Land and Resource Engineering, Kunming University of Science and Technology, Kunming 650093, China \\ ${ }^{2}$ College of Resources and Environmental Engineering, Guizhou University, Guiyang 550025, China \\ ${ }^{3}$ State Key Laboratory of Ore Deposit Geochemistry, Institute of Geochemistry, Chinese Academy of Sciences, Guiyang 550002, China
}

Correspondence should be addressed to Bo Li; libo8105@qq.com

Received 9 May 2020; Revised 30 July 2020; Accepted 7 August 2020; Published 1 September 2020

Academic Editor: Marcello Liotta

Copyright (C) 2020 Bo Li et al. This is an open access article distributed under the Creative Commons Attribution License, which permits unrestricted use, distribution, and reproduction in any medium, provided the original work is properly cited.

\begin{abstract}
Located in the eastern part of the Tethyan tectonic domain, the Jinshajiang Suture Belt (JSB), northwestern Yunnan, China, is notable for its large-scale distribution of Jurassic to Triassic granitoids that are genetically related to the evolution of the PaleoTethys Ocean and polymetallic mineralization. In this study, geochronological and geochemical analyses were conducted on three samples of these granite porphyries (GPs) using laser ablation inductively coupled plasma mass spectrometry and zircon $\mathrm{U}-\mathrm{Pb}$ aging to reveal ages of $213 \pm 15,198.4 \pm 8.6$, and $195.3 \pm 6.4 \mathrm{Ma}$, respectively. These ages are younger than the emplacement ages of the granodiorites, at 208-239 Ma, suggesting that magmatic activities in the Yangla mining district likely continued for $\sim 44 \mathrm{Ma}$. These GPs are rich in large-ion lithophile elements such as $\mathrm{Rb}, \mathrm{Ba}$, Th, U, K, and La but are deficient in high field strength elements such as $\mathrm{Ta}, \mathrm{Nb}, \mathrm{Ce}, \mathrm{Zr}, \mathrm{Hf}$, and Ti. Significant Pb enrichment and $\mathrm{P}$ depletion were noted, as were varying degrees of metallogenic element enrichment in the order of $\mathrm{Cu}>\mathrm{Pb}>\mathrm{Zn}$. The total content of rare earth elements ( $\Sigma$ REEs) of the GPs is in the range of 50.41-127.27 ppm and the LREE/HREE ratio is in the rage of 4.46-10.54. The GPs are rich in LREEs, with a high degree of differentiation noted between the LREEs and HREEs. The $\delta \mathrm{Eu}\left(\mathrm{Eu}_{\mathrm{N}} / \mathrm{Eu} *\right)$ and $\delta \mathrm{Ce}$ $\left(\mathrm{Ce}_{\mathrm{N}} / \mathrm{Ce} *\right)$ values, at $0.53-0.86$ and $0.79-0.98$, indicate weak and slightly weak negative anomalies, respectively. The geochemical characteristics of the GPs indicate that these bodies are slightly metaluminous to peraluminous S-type granites in a calc-alkaline series that formed in a late-collisional or postcollisional tectonic setting. Three-component mixing of magmas including those of upper crust, lower crust, and mantle materials in addition to subsequent partial melting could have been responsible for the generation of these GPs in an epithermal low-pressure setting at $<5 \mathrm{kbar}$.
\end{abstract}

\section{Introduction}

The Sanjiang Metallogenic Belt (SMB), including the Jinshajiang, Lancangjiang, and Nujiang rivers, is an economic skarn-porphyry $\mathrm{Cu}$ polymetallic metallogenic belt situated in SW China (Figures 1(a) and 1(b)). The metallogenic processes in the SMB occurred mainly during a Mesozoic $(\sim 230 \mathrm{Ma})$ late-collisional or postcollisional tectonic setting [1-3]. This belt consists mainly of seven geotectonic units including the Ganzi-Litang Suture Belt, Zhongzan-Zhongdian Plates, Jinshajiang Suture Belt (JSB), Qamdo-Simao Terranes, Nujiang Suture Belt, Lancangjiang Suture Belt, and Lhasa Terranes from east to west $[2,4]$. The SMB includes widespread ore-related granites, including Indosinian (Triassic to Late Jurassic) granitoids in large proportions [2-4]. Granitic porphyries (GPs) closely associated with $\mathrm{Cu}$ mineralization were discovered in 2014 by geological prospectors of the Yunnan Copper Industry Group in a tunnel at depths of $3250 \mathrm{~m}$ and $3275 \mathrm{~m}$. The locations of these GPs suggest the potential contribution of porphyry plutons to the $\mathrm{Cu}$ deposits at depth. However, the ore-related GPs in the deep part of the Yangla mining district have received little research attention. Previous studies have shown that the JSB and its surrounding district contain the Sanjiang 


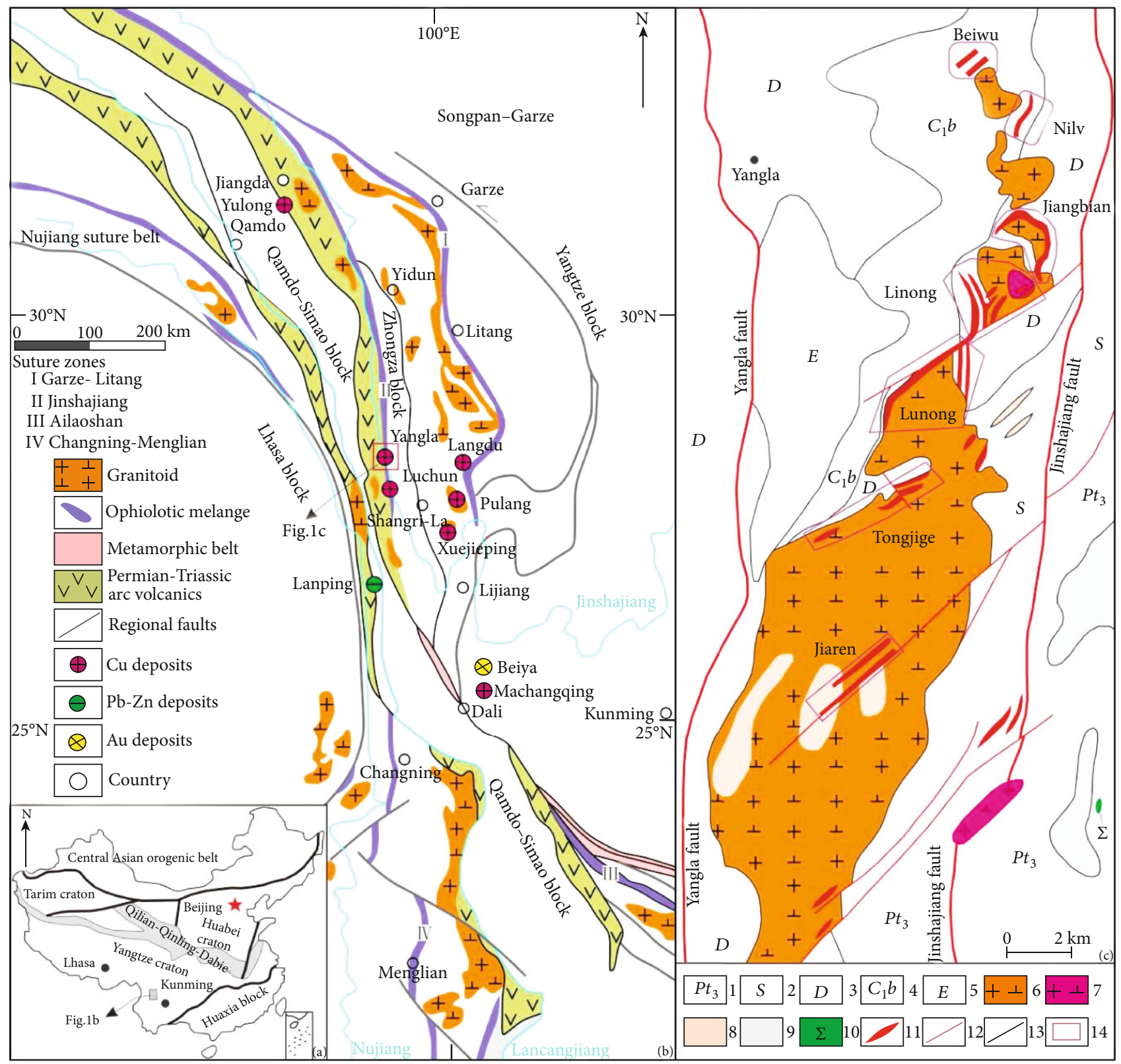

Figure 1: (a) Geotectonic framework map of China showing the location of the Sanjiang Orogen (after [2]). (b) Regional geological map of the Sanjiang region (SW China), showing the major geological terranes, suture zones, volcanic belts, and locations of the major ore deposits (modified after [3]). (c) Geologic map of the Yangla Cu deposit showing the distribution of the major ore-related intrusion, faults, ore block, and ore bodies (modified after [23]). 1-Gajinxueshan Group, 2-Silurian, 3-Devonian, 4-Carboniferous Beiwu Formation, 5-Tertiary, 6-granodiorite, 7-granitic porphyry, 8-monzonite granite, 9-quartz-diorite, 10-Hercynian (ultrabasic rock), 11-ore body, 12-faults, 13-geological boundary, and 14-ore block.

region's most important $\mathrm{Cu}-\mathrm{Pb}-\mathrm{Zn}-\mathrm{Au}$ metallogenic belt, which is genetically associated with host granite plutons $[1-3,5,6]$. Therefore, obtaining accurate constraints on the nature and age of these ore-related GPs has a particular significance for our understanding of the tectonic evolution and metallogeny of the JSB.

Situated at latitude $28^{\circ} 51^{\prime}-28^{\circ} 59^{\prime} \mathrm{N}$, longitude $99^{\circ} 04^{\prime}-$ $99^{\circ} 07^{\prime} \mathrm{E}$ in the central part of the JSB between the Zhongzan-Zhongdian and Qamdo-Simao plates, the Yangla $\mathrm{Cu}$ deposit (YCD) is one of the most important $\mathrm{Cu}$ deposits in the Sanjiang region. The YCD contains $\mathrm{Cu}$ reserves of $150 \mathrm{Mt}$ with an average grade of $1.03 \%$. This large skarn-porphyry $\mathrm{Cu}$ deposit has attracted considerable attention since its mining began in $2007[2,5,6]$, particularly during the last 10 years. However, previous studies have focused mainly on the geochemical signatures and related mineralization of the granodiorite plutons including Beiwu, Linong, and Lunong intrusions $[1-3,7,8]$; little research has been conducted on the newly discovered GPs in the Yangla mining district. In the present study, we integrate the zircon $\mathrm{U}-\mathrm{Pb}$ 


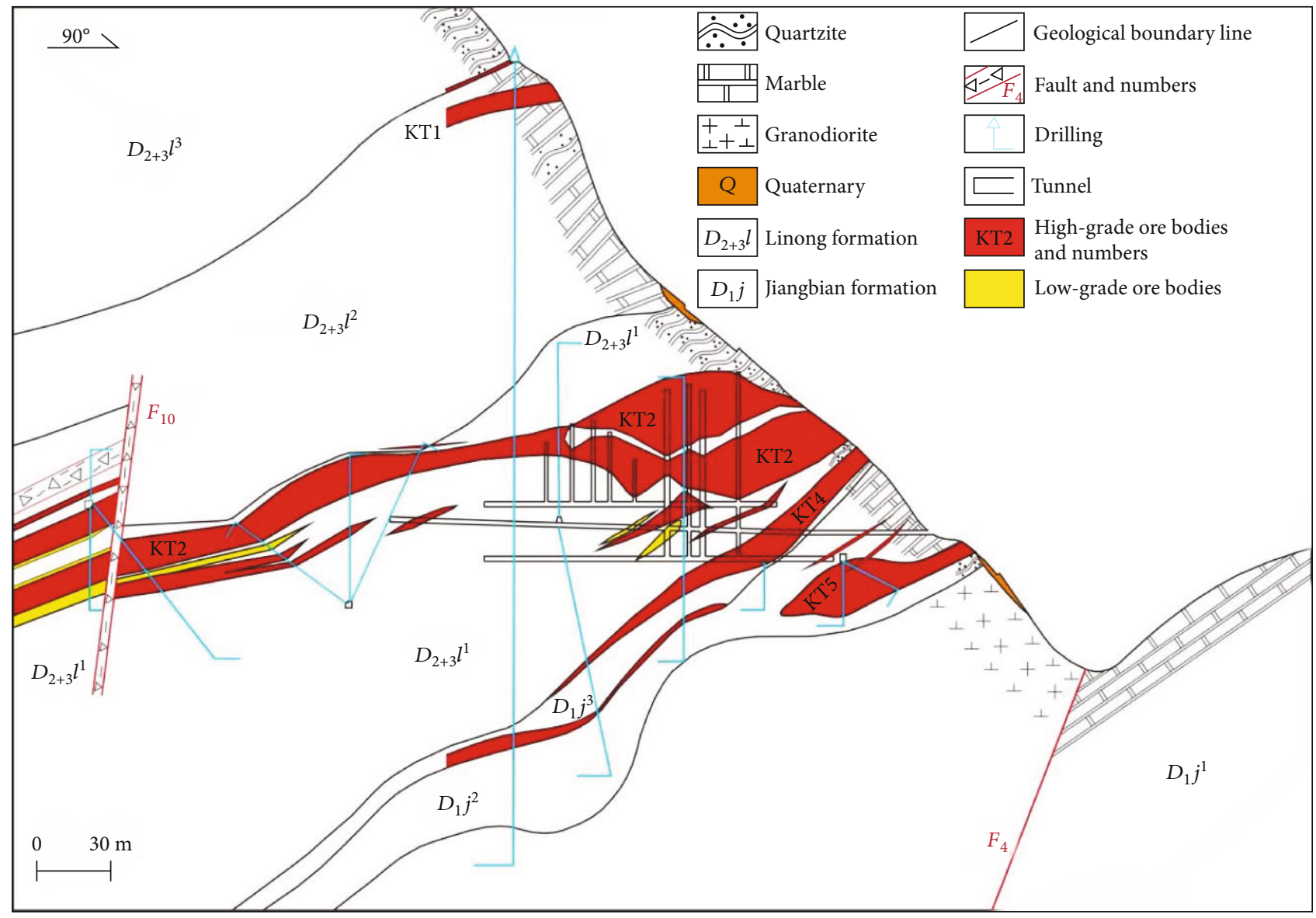

FIGURE 2: The no. 25 prospecting line profile map in Yangla copper deposit, Yunnan, China (after Reference [52]).

ages of these GPs with data of their whole-rock major elements, trace elements, and rare earth elements (REEs) and compare the results with the geochemical features of the Yangla granodiorite plutons of the YCD $[2,4]$ to better understand the formation of the geotectonic setting of these GPs and granodiorite plutons.

\section{Setting}

2.1. Regional Geology. The Sanjiang region is located at the southwestern edge of the Yangtze Craton, SW China (Figure 1(a)) and is a key component of the eastern Tethyan-Himalayan metallogenic belt. The region is characterized by several NW-SE-trending ophiolite suture zones with regional-scale thrusts and an adjacent magmatic belt that separate several microcontinental blocks [3]. In addition, this region contains one of the country's prime polymetallic terrane and as well as numerous deposits of important precious metals (Figure 1(b)). Numerous igneous rocks and related giant ore deposits associated with the evolution of the Tethys Ocean were generated since the Paleozoic, including the Garzê-Litang Belt, which contains the Langdu $\mathrm{Cu}-$ $\mathrm{Pb}-\mathrm{Zn}$, Pulang $\mathrm{Cu}$, and Xuejiping $\mathrm{Cu}$ deposits, and the JSB, which comprises the Yulong $\mathrm{Cu}-\mathrm{Au}-\mathrm{Mo}$, Yangla $\mathrm{Cu}$, Luchuan $\mathrm{Cu}-\mathrm{Pb}-\mathrm{Zn}$, Beiya $\mathrm{Cu}-\mathrm{Au}-\mathrm{Pb}-\mathrm{Ag}$, and Machangqing $\mathrm{Cu}-\mathrm{Mo}-\mathrm{Au}$ deposits [9-14].
The JSB is situated in the eastern Sanjiang domain and likely connects with the Ailaoshan Suture to the southeast, which underwent a complex evolution process from the late Paleozoic to the Neogene involving subduction of the Jinshajiang Ocean, arc-continent collision, post-collisional processes, and strike-slip faulting $[15,16]$. Published U-Pb zircon ages of igneous rocks in this area indicate that the Jinshajiang Ocean likely formed during the early Carboniferous (343.5-347 Ma [17, 18]) with westward-directed subduction occurring beneath the Qamdo-Simao Terrane in the Early Permian (285 Ma [17, 19]). Subsequently, the Jinshajiang Ocean gradually closed and ultimately disappeared. The earliest phases of collision produced high-silica rhyolites of Early Triassic age (247-246 Ma [20]). At the same time, the subduction and closure of the Jinshajiang Ocean resulted in partial melting of the lower crust, which formed large amounts of intermediate-to-evolved magma and resulted in large-scale volcanic and magmatic activity. These events, represented by high-K calc-alkaline granitoids 234-214 Ma in age, suggest that the Late Triassic was a period of early tectonic collapse and thermal relaxation in a postcollisional setting $[2-4,15]$. Associated felsic intrusive activity and metal mineralization have been identified in this region. The Triassic granitoids are represented by the Baimaxueshan ( 248 Ma [21]), Ludian (234-214 Ma [21]), and Jiaren ( 230 Ma [4]) intrusions, which formed possibly 
TABLE 1: The statistical data of the diagenetic and metallogenic ages in Yangla copper deposit, Yunnan, China.

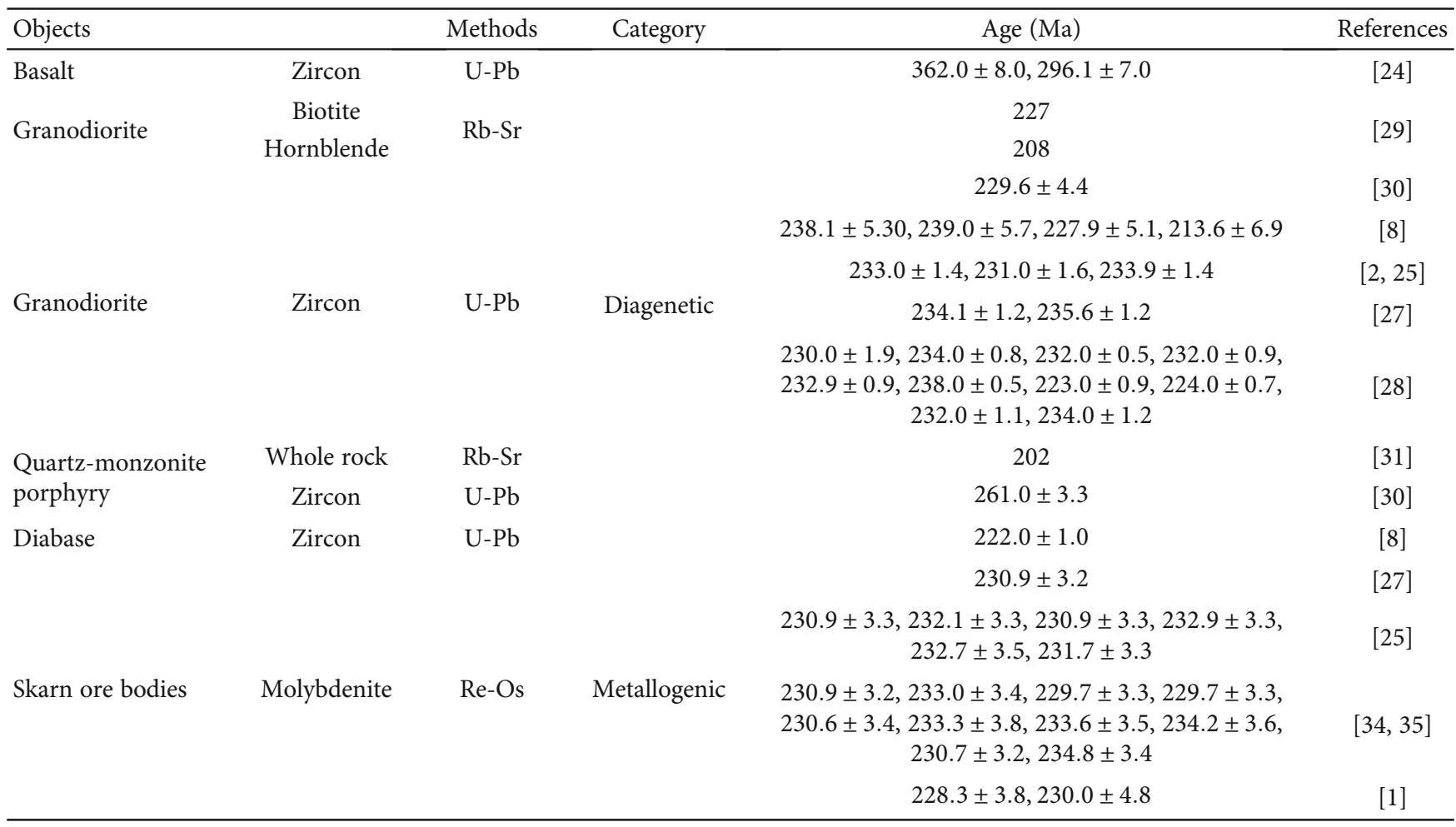

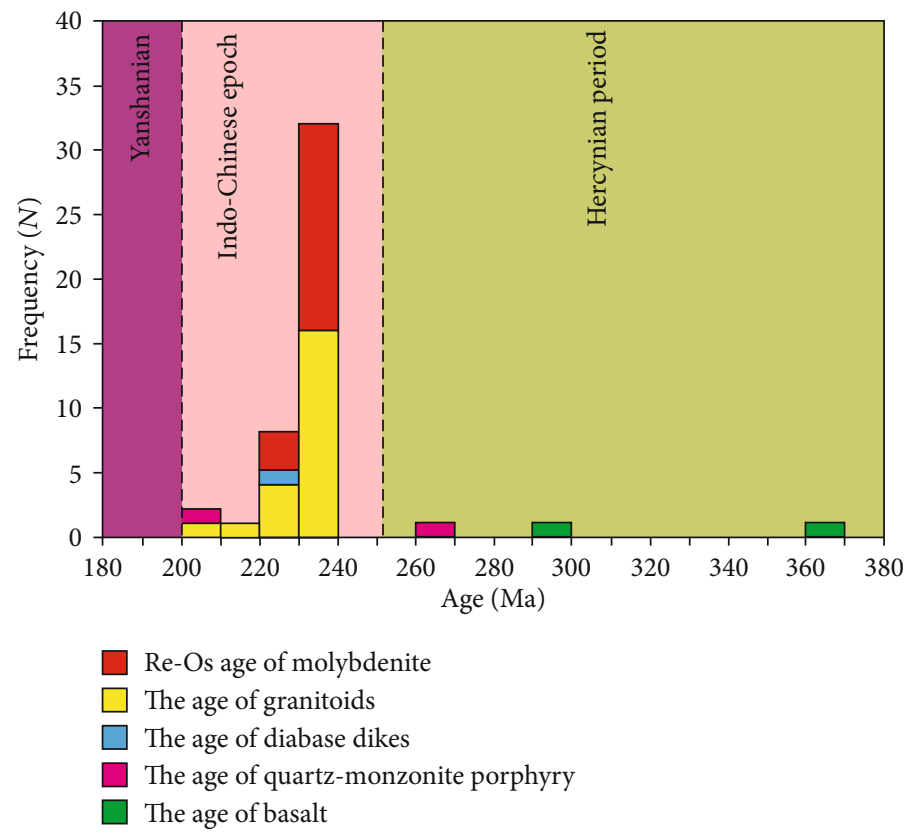

FIGURE 3: The histogram of diagenetic and metallogenic ages of the Yangla copper deposit, Yunnan, China (the data after References [1, 2, 8, $24,25,27-31,34,35$, and]).

after the closure of the Jinshajiang Ocean in a postcollisional tectonic setting $[4,15]$. Secondary ion mass spectrometry (SIMS) zircon $\mathrm{U}-\mathrm{Pb}$ analysis has indicated an age of $\sim 230 \mathrm{Ma}$ for the Jiaren intrusions, which are located south of the Yangla ore district in an area of $\sim 150 \mathrm{~km}^{2}[2,4]$.
Accordingly, the YCD is suggested to have a genetic association with the Jiaren intrusion in the JSB [2-4].

2.2. Yangla Ore Deposit Geology. The YCD is located in the central part of the JSB, which is bounded by the regional 


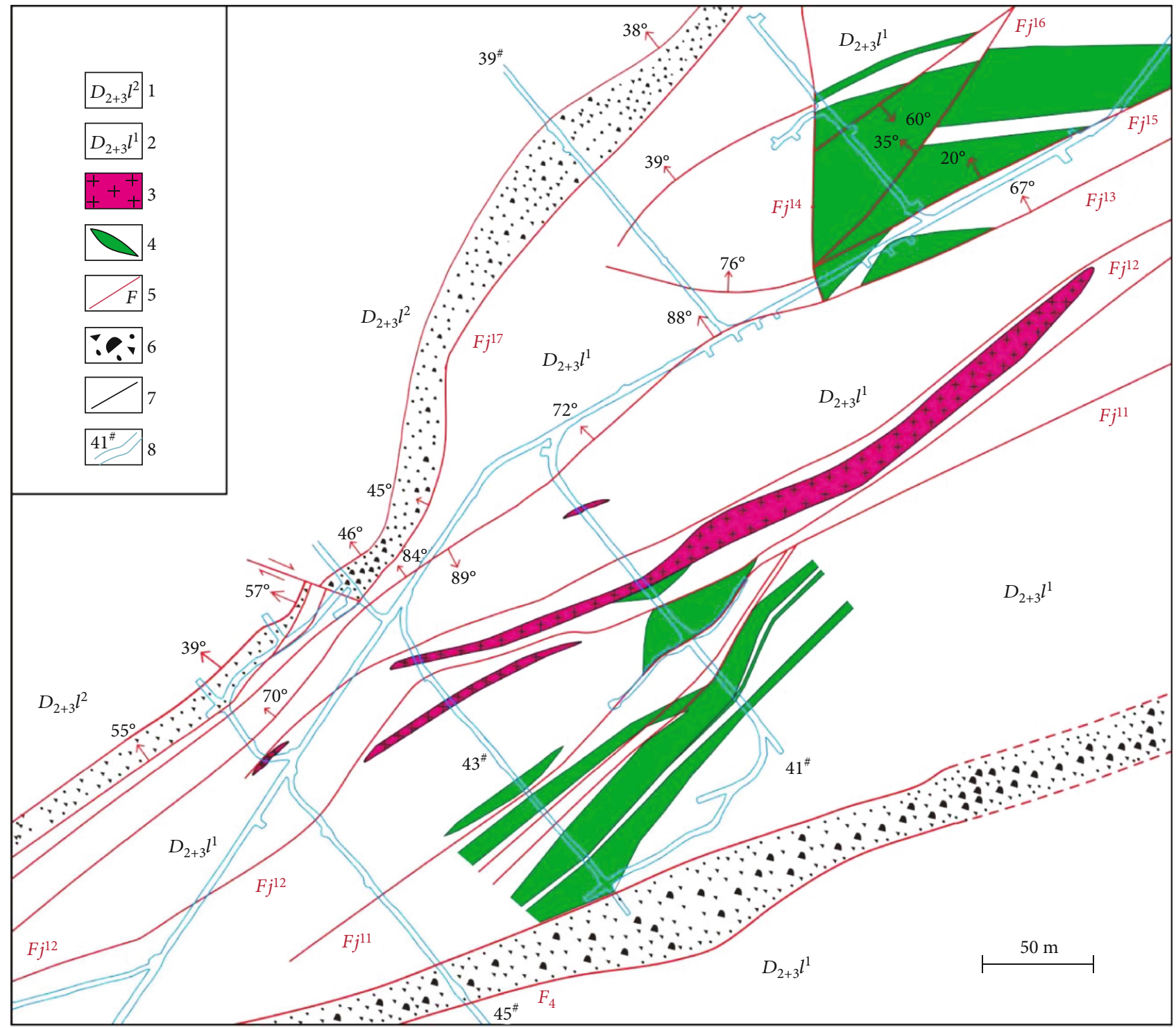

Figure 4: The underground tunnel 3,250 m section map of the Yangla copper deposit, Yunnan, China. 1: Devonian (Linong Formation); 2 : Devonian (Jiangbian Formation); 3: granitic porphyry; 4: copper ore body; 5: fault and corresponding number; 6: fracture zone; 7: geological boundary line; and 8: tunnel and corresponding number.

N-S-trending Jinshajiang Fault to the east and the Yangla Fault to the west. Previous exploration has determined that the YCD consists mainly of seven ore blocks including the Beiwu, Nilv, Jiangbian, Linong, Lunong, Tongjige, and Jiaren, from north to south (Figure 1(c)). However, only the Linong and Lunong ore blocks, which are separated by the NEtrending F4 normal fault $[22,23]$ in the central part of the Yangla ore district, are recognized as having economic importance at present. The Linong ore block is the largest block and contains $\mathrm{Cu}$ reserves of $1.5 \mathrm{Mt}$ with an average grade of $1.03 \%$, accounting for $90 \%$ of the entire Yangla $\mathrm{Cu}$ reserves. In the present study, we focus primarily on the granite porphyry (GP) of the Linong ore block.

The exposed stratigraphy in the Yangla mining district is dominated by (i) Silurian units, (ii) Devonian Jiangbian and Linong formations, and (iii) the Carboniferous Beiwu Formation (Figure 1(c)). The Silurian sequences, which crop out in the southeastern part of the Yangla mining district, consist mainly of quartz schist, biotite-quartz schist, quartzite, and sericite slate. The sequences of the Devonian Jiangbian and Linong formations, which predominantly comprise garnet-diopside skarn, fine-grained marble, quartzite, sericitic slate, and sericitic schist, crop out in the middle and southeastern parts of the Yangla mining district and are the main hosts of the $\mathrm{Cu}$ ore bodies. The stratiform-stratoid, vein, and lenticular $\mathrm{Cu}$ ore bodies (KT1, $\mathrm{KT} 2$, and KT3, respectively) are hosted in interlayer fracture zones in the Linong Formation (Figure 2). The vein-like $\mathrm{Cu}$ ore bodies KT4 and KT5 are hosted in the interlayer fracture zones in the Jiangbian Formation (Figure 2). The Carboniferous Beiwu Formation crops out in the western part of the Yangla mining district and consists mainly of sericite slate and massive basalt, which are not closely associated with the $\mathrm{Cu}$ mineralization. 


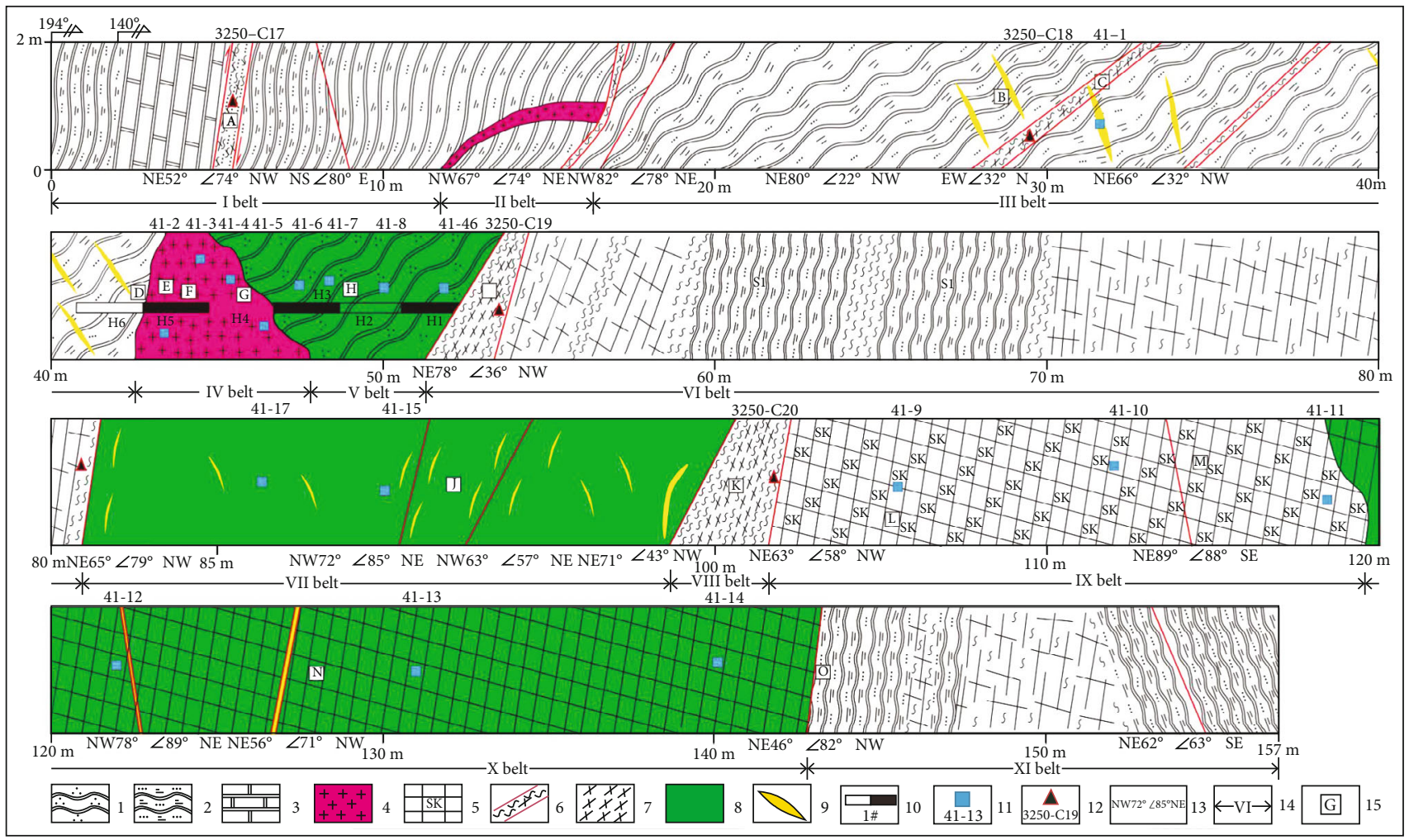

FIGURE 5: Sketch map of Stope 41 in the tunnel 3,250 m section, Yangla copper deposit, Yunnan, China. 1: quartzite; 2: sericitic sandy slate; 3: marble; 4: granite porphyry; 5: skarn; 6: fracture zone; 7: tectonic cataclastic rocks; 8: copper ore body; 9: quartz-calcite vein; 10: base samples and corresponding numbers; 11: specimen and corresponding numbers; 12: tectonic geochemical samples and corresponding numbers; 13 : fracture occurrence; 14: mineralization-lithologic alteration zones and corresponding numbers; and 15: locations and corresponding numbers of photographs (Figure 6). Zone I: weak chloritization-pyritization-silicification; Zone II: fine-veined calcitized-pyritized granite porphyry; Zone III: strong silicification-calcitization-weak pyritization; Zone IV: granite porphyry vein with strong silicification and calcitization, pyritization, chalcopyritization, and molybdenitization; Zone V: skarn-type copper ore body; Zone VI: fracture crushing zone; Zone VII: massive ore-rich body; Zone VIII: fracture crushing zone; Zone IX: yellowish-brown-brown massive garnet skarn; Zone $\mathrm{X}$ : massive skarn-type ore body; and Zone XI: weakly skarnified sericitic sandy slate and metamorphic quartz sandstone.

The structure in the Yangla mining district is well developed and includes folds and faults. The Jinshajiang Fault is a regional-scale thrust fault that dips to the west at $60-80^{\circ}$, and the Yangla Fault dips to the east at $30-70^{\circ}$ [3]. These faults controlled the distribution of the regional magmatic zone. The NE-trending normal fault F4, which is approximately $6 \mathrm{~km}$ long, and the related parallel faults in the Yangla mining district have dip direction NW and dip angles in the range of $42-80^{\circ}$, and controlled the spatial orientation of the $\mathrm{Cu}$ ore body and intrusions (Figure 1(c)). In addition, fracture zones and secondary structural fissures, which were widely developed by regional compression during the Triassic Indosinian Orogeny and by emplacement of the Jiaren granitoid at $\sim 230 \mathrm{Ma}$ [22], controlled the spatial orientation, outcrop occurrence, and morphology of the skarn $\mathrm{Cu}$ ore bodies and intrusions. The Linong Anticline and Jiangbian Syncline are the major fold structures in the Yangla mining district $[5,6]$.

The magmatic rocks in the YCD, including basalt, granodiorite, quartz-monzonite porphyry, and diabase, are distributed over a relatively large area. The zircon $\mathrm{U}-\mathrm{Pb}$ ages of the basalts $(362.0 \pm 8.0 \mathrm{Ma}$ and $296.1 \pm 7.0 \mathrm{Ma})$, which crop out in the northwest part of the Yangla mining district [24] (Table 1, Figure 3), suggest basalt formation during the
Hercynian period. These basalts could have formed in the expanded setting of the enriched mantle source area or by ocean spreading of the ocean basin behind the arc of the Jinshajiang; however, these events are not significantly related to the $\mathrm{Cu}$ mineralization [24-26]. The granodiorite and quartz-monzonite porphyry intrusion occurs in the middle part of the Yangla and exhibits an oval shape that is approximately $2 \mathrm{~km}$ in length and $1.5 \mathrm{~km}$ in width with a total exposed area of $2.6 \mathrm{~km}^{2}[2,4]$. The granodiorite has been identified as I-type granite containing a mixed source of crustal- and mantle-derived magma $[2,3,6]$. Previous studies have shown that the granodiorite, with emplacement ages mostly in the range of 208-239 Ma (Table 1, Figure 3) [8, 25, 27-30], formed during the Indosinian orogeny, and might have formed in the late-collisional or postcollisional setting of the Jiangda-Weixi volcanic arc and the Qamdo-Simao block, which are closely related to the $\mathrm{Cu}$ mineralization [25]. The whole rock $\mathrm{Rb}-\mathrm{Sr}$ and zircon $\mathrm{U}-\mathrm{Pb}$ ages of the quartz-monzonite porphyry are $202 \mathrm{Ma}$ and $261.0 \pm 3.3 \mathrm{Ma}$, respectively, and have little relation with the $\mathrm{Cu}$ mineralization $[30,31]$. The zircon $\mathrm{U}-\mathrm{Pb}$ age of the diabase is $222.0 \pm 1.0 \mathrm{Ma}$, indicating formation during the Indo-China epoch $[8,32]$. This body also has little relation with the $\mathrm{Cu}$ mineralization. 


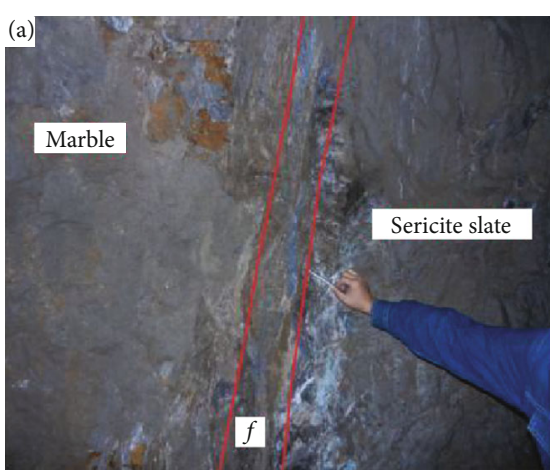

(a)

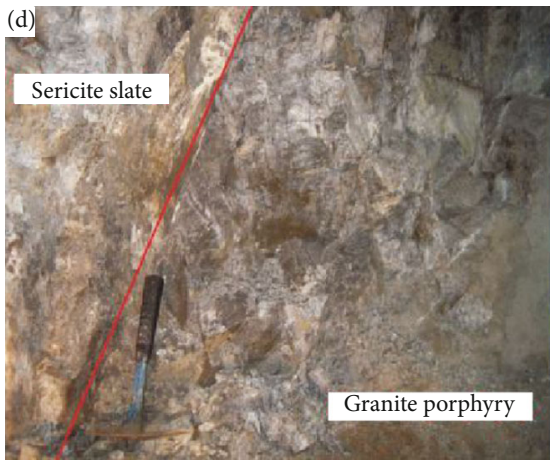

(d)

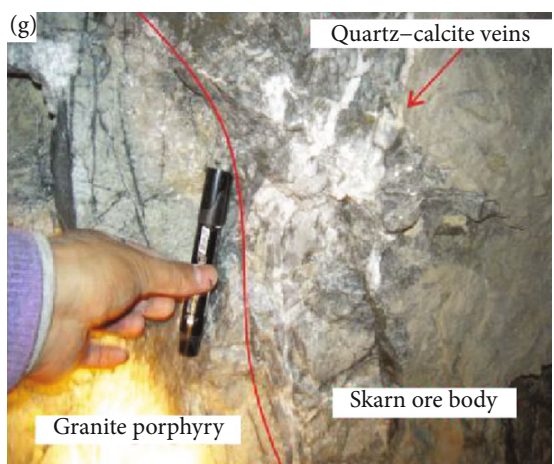

(g)

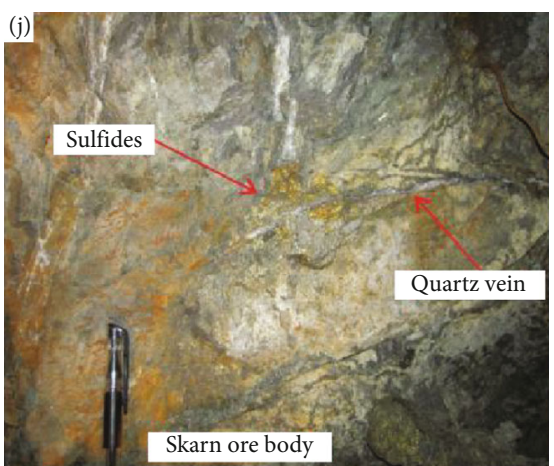

(j)

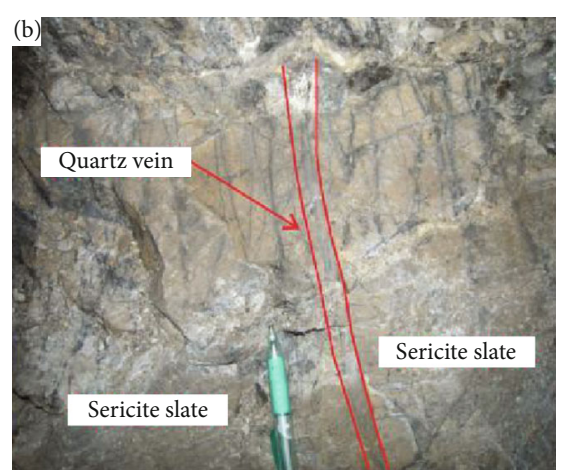

(b)

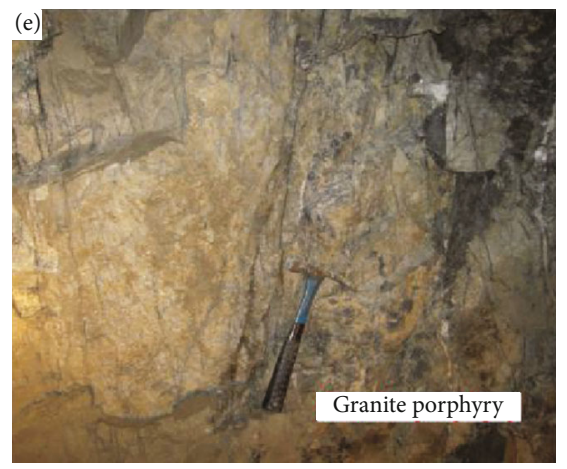

(e)

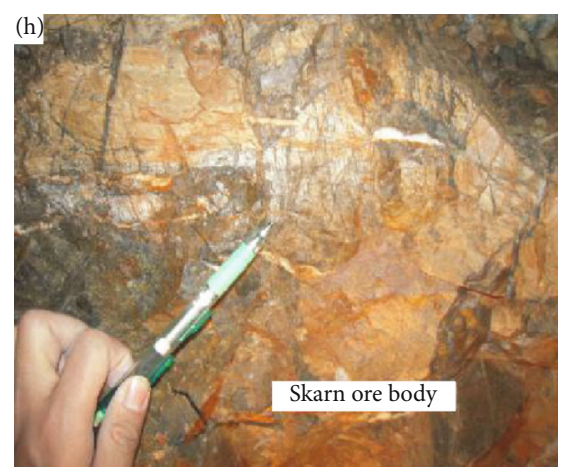

(h)

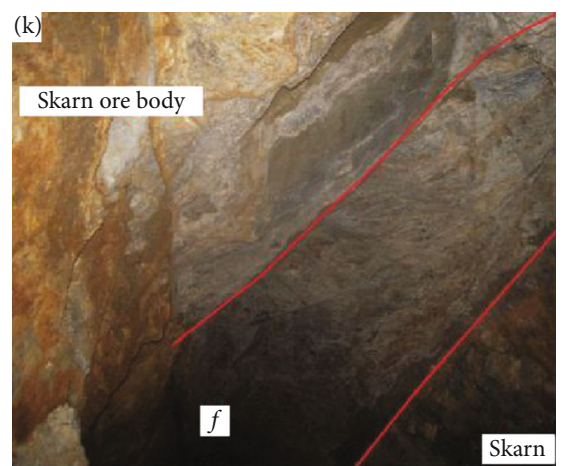

(k)

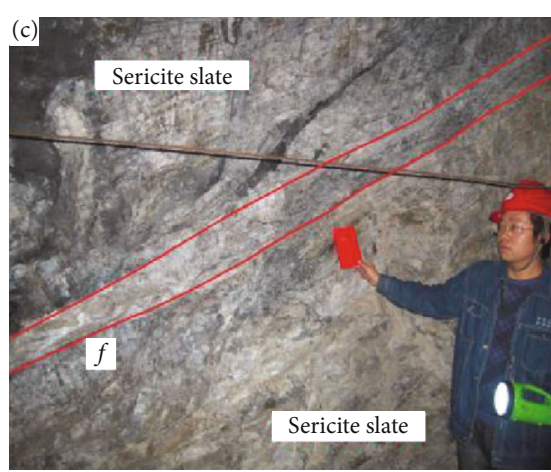

(c)

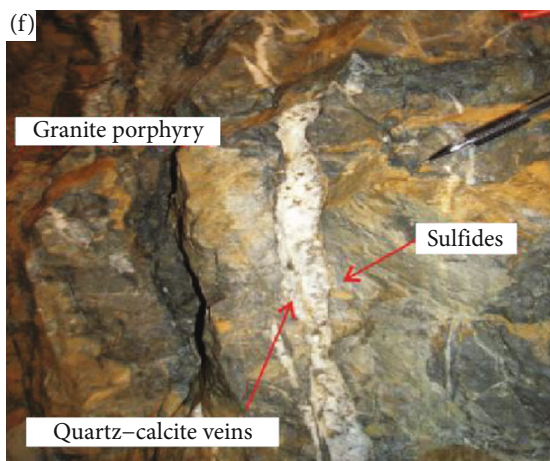

(f)

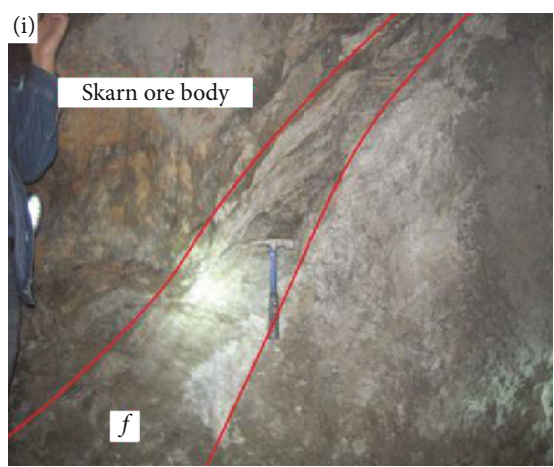

(i)

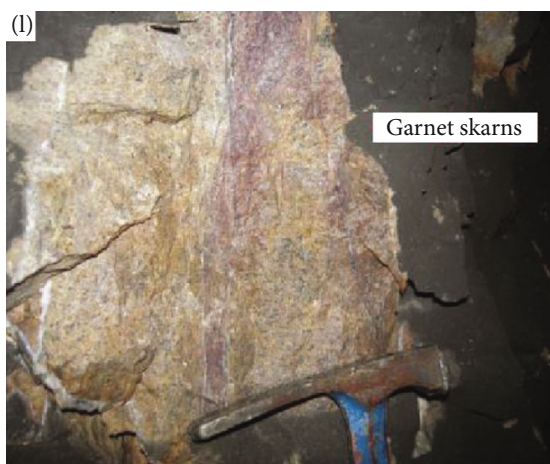

(l)

Figure 6: Continued. 


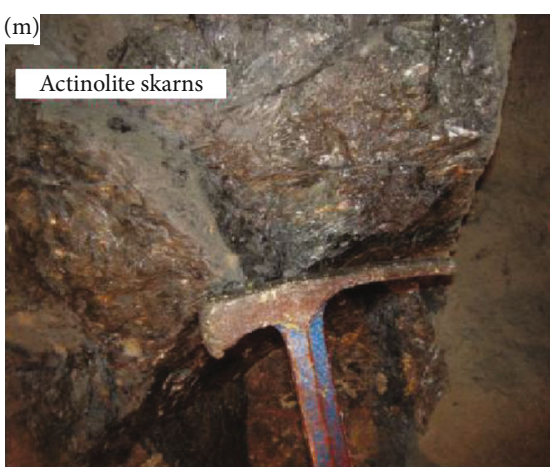

$(\mathrm{m})$

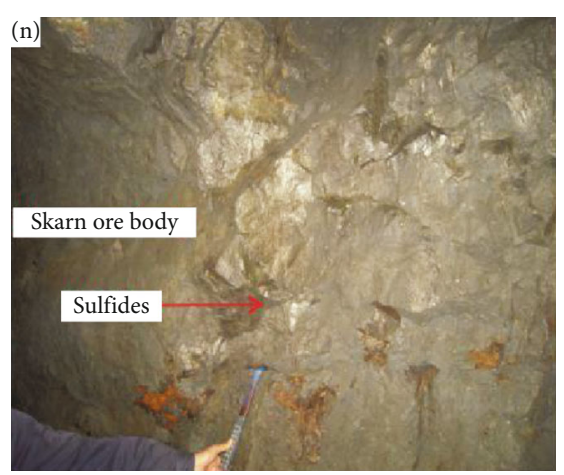

(n)

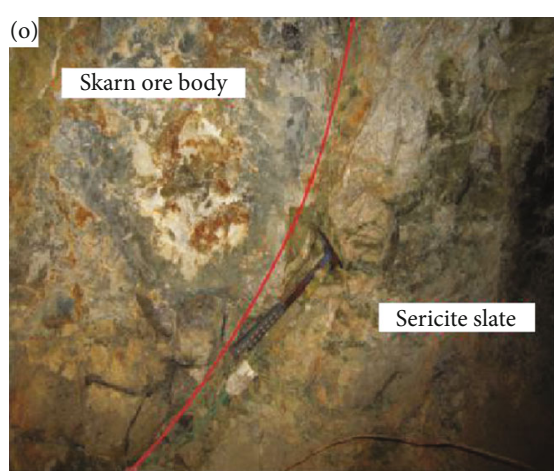

(o)

FIgURE 6: Photographs of stope $41^{\#}$ in the tunnel 3,250 m section, Yangla copper deposit, Yunnan, China. (a) Fault with upper and lower plates of marble and sericitic sandy slate, respectively. The zone's in-fill materials include tectonic cataclastic rocks, crushed rocks, and marble breccia. (b) Quartz vein developed within sericitic sandy slate. (c) Interlayer fault developed within sericitic sandy slate. The zone's in-fill materials are cataclastic rocks and fault gouge. (d) Irregular contact line between sericitic sandy slate and granite porphyry. (e) Granite porphyry. (f) Quartz-calcite veins with scattered, disseminated sulfides (pyrite and chalcopyrite) developed in the granite porphyry. (g) Irregular contact line between granite porphyry and skarn ore body. Quartz-sulfide veinlets developed in the granite porphyry, whereas large amounts of quartz-calcite veins and disseminated metal sulfides (pyrite and chalcopyrite) developed in the skarn ore body. (h) Skarn ore body with large amounts of veined and disseminated metal sulfides (pyrite and chalcopyrite). (i) Fault-fracture zone at the floor of the skarn ore body. The upper and lower plates are skarn ore body and fault fracture zone, respectively. The zone's infill materials are tectonic cataclastic rocks. (j) Skarn ore body with quartz veins and large amounts of veined and disseminated metal sulfides (pyrite and chalcopyrite). (k) Fault-fracture zone between the skarn ore body and skarn. The upper and lower plates are the skarn ore body and the skarn, respectively. The zone's in-fill materials are tectonic cataclastic rocks. (l) Garnet skarn. (m) Actinolite skarn. (n) Skarn ore body with large amounts of disseminated pyrrhotite, pyrite, chalcopyrite, and other metal sulfides. (o) Irregular contact line between skarn ore body and sericitic sandy slate.

The YCD Cu ore bodies in the exoskarn zones or within the intrusion-distal interlayer fracture zones are generally stratiform, stratoid, bedded, veined, or lenticular and dip gently to the west at angles of $30^{\circ}-40^{\circ}$. The main ore body types are skarn, hornfels, porphyries, and hydrothermal veins [33]. The major ore bodies KT2, KT4, and KT5 are mainly skarn ore bodies and account for $90 \%$ of the $\mathrm{Cu}$ resources in the Linong ore block. The molybdenite Re-Os ages of the skarn ore bodies are 228-234 Ma, with an average age of $230 \mathrm{Ma}$ (Table 1, Figure 3) [1, 25, 27, 34, 35]. This indicates that the skarn ore bodies formed during the Indo-China epoch, which is consistent with the emplacement ages $(208-239 \mathrm{Ma})$ of the granodiorites with an average age of $230 \mathrm{Ma}$. The predominant ore minerals are chalcopyrite, pyrite, and pyrrhotite; small amounts of bornite, galena, molybdenite, sphalerite, malachite, and covellite are also present [36]. The gangue minerals include quartz, calcite, mica, plagioclase, diopside, and garnet [36, 37]. Automorphic-xenomorphic granular, cataclastic, and interstitial textures are most common in the sulfide ores; the ore structures are mainly dense massive, disseminated, veined, or banded $[26,33,36]$.

2.3. Petrography of the Granite Porphyries. The GPs occur in an underground tunnel in $3250 \mathrm{~m}$ - and $3275 \mathrm{~m}$-deep sections of the Linong ore block (Figure 4, Figure 5), where they are emplaced within light gray-grayish-white quartzite, sericitic slate, and sericitic schist of the Linong Formation $\left(D_{2+3} l\right)$. The width and length ranges of the GPs are 4-5 $\mathrm{m}$ and 20$300 \mathrm{~m}$, respectively. The GPs formed within a NE-trending fault zone that has a NE strike of $60^{\circ}$ and a NW dip of approximately $40^{\circ}$. The contact boundary lies between the GPs and the wall rocks are irregular; the internal and external contact zones underwent minor alterations including silicification, sericitization, chloritization, carbonation, and argillization (Figure 5, Figure 6).

The grayish-white GPs exhibit porphyritic texture and massive structure (Figures $7(\mathrm{a})-7(\mathrm{f})$ ). The main phenocrysts are quartz and plagioclase, at approximately $20 \%$ and $10 \%$, respectively, with a small amount of biotite at less than $2 \%$. The size of the quartz phenocrysts is generally $1-5 \mathrm{~mm}$, although the largest are almost $20 \mathrm{~mm}$. The shapes are mostly hexagonal, quadrangular, irregular, and euhedral to subhedral, with some exhibiting corrosion edges. Most of the plagioclase phenocrysts have particle sizes in the range of 1-3 mm, with the largest at approximately $20 \mathrm{~mm}$. These phenocrysts are altered as sericite, chlorite, and kaolinite pseudomorp. The biotite phenocrysts are generally less than $2 \mathrm{~mm}$ in size and similarly retain only their external shape, having been replaced by sericite and other minerals (Figures 7(g)-7(i)). Zircon, pyrite, chalcopyrite, and other minor sulfide minerals occur as accessory minerals. The matrix is cryptocrystalline-microcrystalline and exhibits felsophyric texture. The main components are quartz and plagioclase, with a small amount of biotite, which underwent minor sericitization, kaolinization, silicification, and carbonation (Figures $7(\mathrm{~g})-7(\mathrm{i})$ ). Finely veined and disseminated chalcopyritization and pyritization accompanied by finely veined and veined calcite and quartz have developed in the GPs and in the wall rocks (Figures $7(1)-7(n))$. The ore 


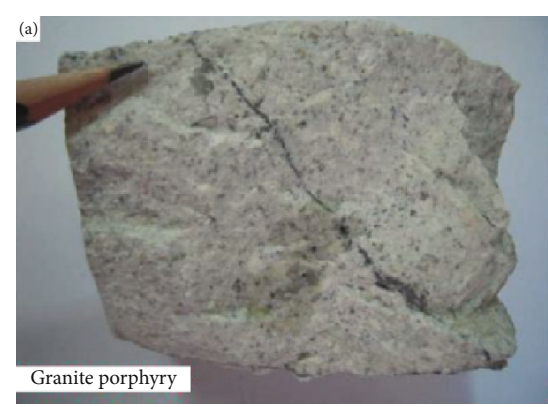

(a)

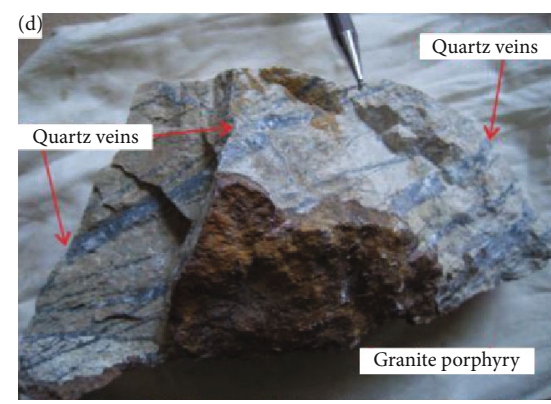

(d)

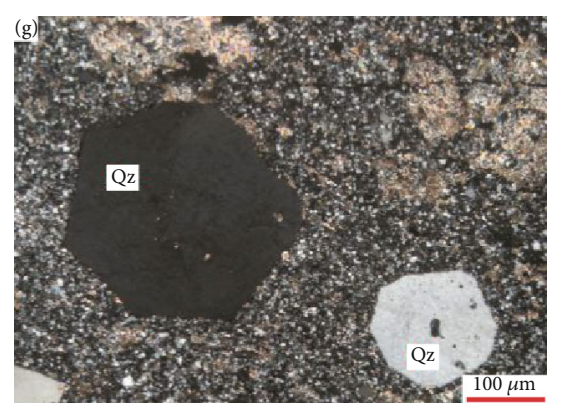

(g)

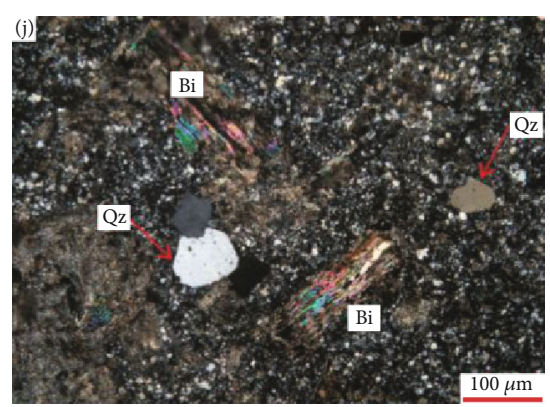

(j)

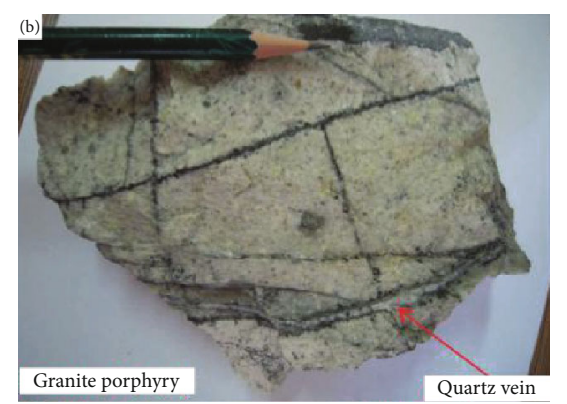

(b)

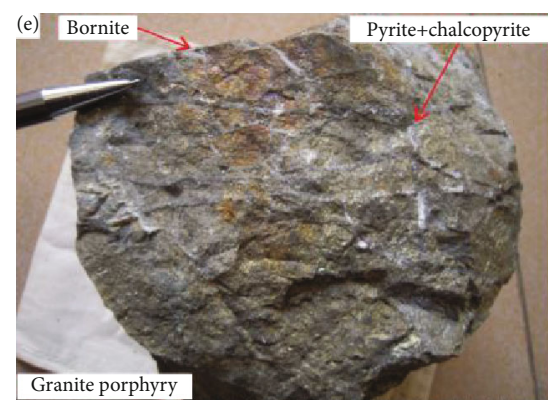

(e)

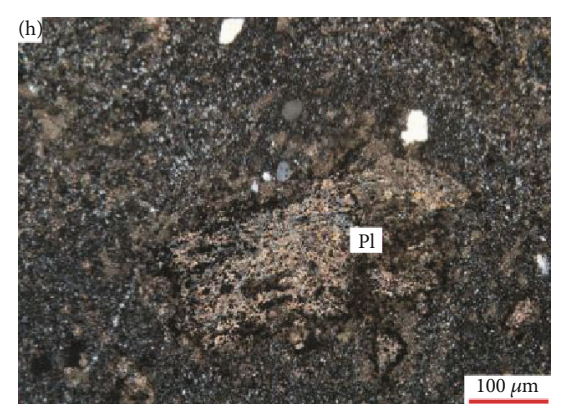

(h)

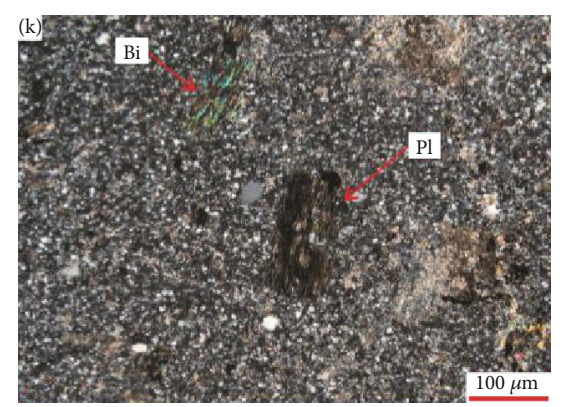

(k)

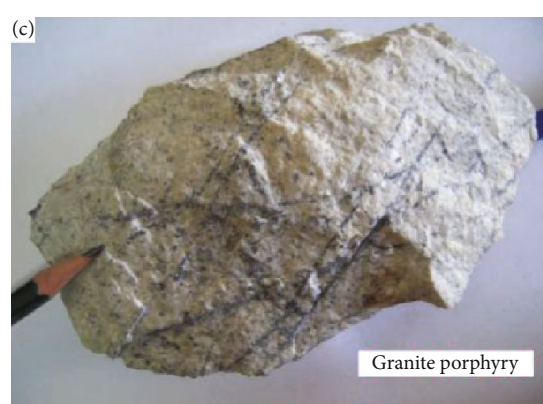

(c)

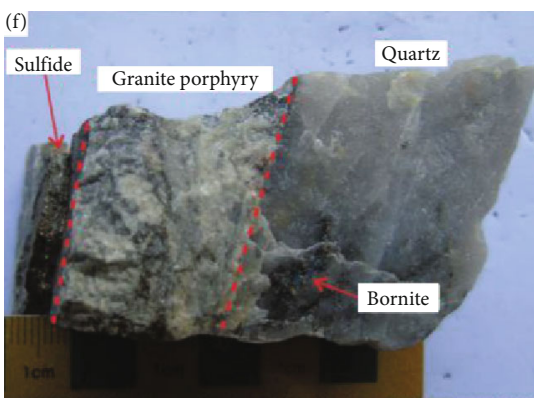

(f)

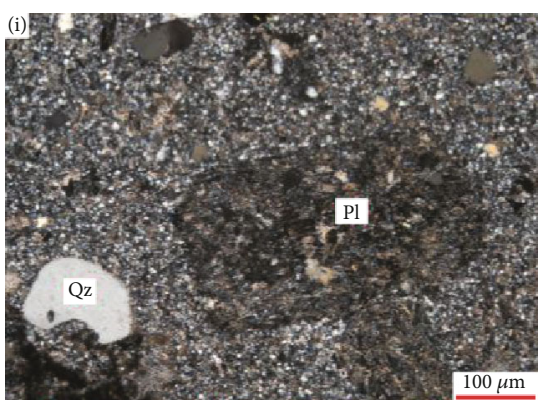

(i)

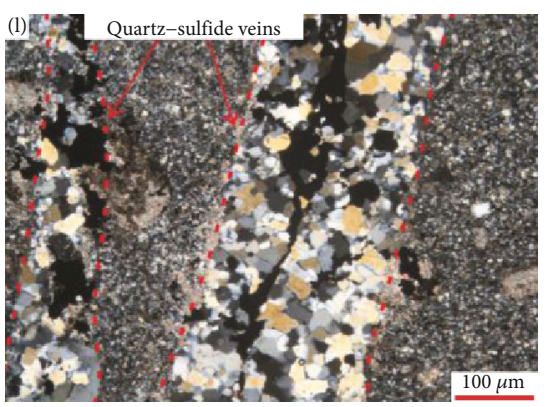

(l)

Figure 7: Continued. 


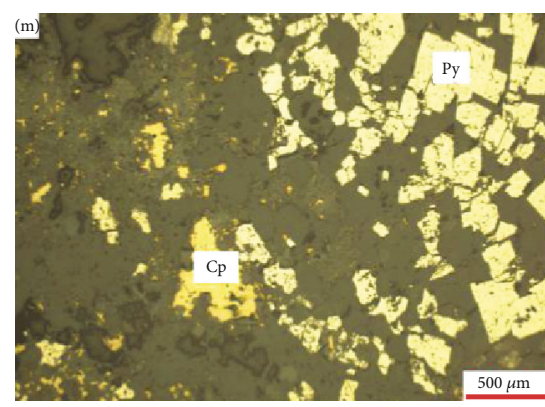

(m)

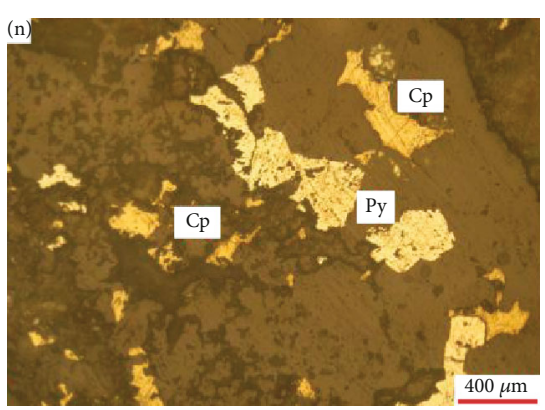

(n)

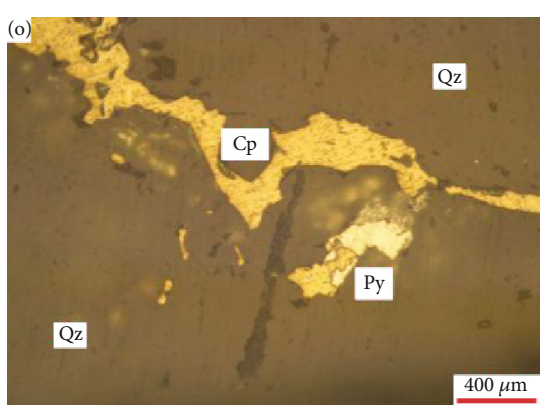

(o)

Figure 7: Macroscopic and microscopic characteristics of the granite porphyries in the Yangla copper deposit, Yunnan, China. (a) Grayishwhite massive granite porphyry. The quartz crystals are semiautomorphic or elongated grains, and the plagioclase phenocrysts, which underwent strong alteration, appear corroded. (b) Grayish-white massive structure granite porphyry with veinlets of metal sulfides (pyrite and chalcopyrite) and quartz. (c) Grayish-white massive structure granite porphyries with large amounts of veined metal sulfides (pyrite and chalcopyrite). (d) Grayish-white massive structure granite porphyry with large amounts of quartz veins. (e) Gray massive structure granite porphyry with large amounts of disseminated pyrite, chalcopyrite, and bornite. (f) Light-grayish to white massive structure granite porphyry with metal sulfide veins (pyrite and chalcopyrite), quartz veins, and disseminated bornite. (g) Porphyritic texture granite porphyry. The phenocrysts are semiautomorphic or elongated grains, the quartz is corroded, and the matrix is microscopic granular plagioclase-quartz. (h) Granite porphyry with blastoporphyritic texture. The phenocrysts are sericitic plagioclase, and the matrix is plagioclase-quartz with a felsitic texture. (i) Granite porphyry with blastoporphyritic texture. The phenocrysts are sericitic plagioclase, the quartz is corroded, and the matrix is microscopic granular plagioclase-quartz. (j) Porphyritic texture granite porphyry. The phenocrysts are automorphic granular quartz and faded biotite, and the matrix is microscopic granular plagioclase-quartz. (k) Granite porphyry with blastoporphyritic texture. The phenocrysts are sericitic plagioclase and faded biotite, and the matrix is microscopic granular plagioclasequartz. (l) Quartz-sulfide veins developed in the granite porphyry. (m) Disseminated chalcopyrite and pyrite. (n) Xenomorphic granular pyrite and chalcopyrite developed along fissures in alternating scattered-disseminated and irregular fine-veined forms. The pyrite is interspersed with chalcopyrite. (o) Chalcopyrite and pyrite in-filled along the quartz veins. The pyrite is xenomorphic and interspersed by chalcopyrite. Qz: quartz; Pl: plagioclase; Bi: biotite; Py: pyrite; Cp: chalcopyrite.

TABLE 2: Statistical of the mineralization elements in granite porphyries and surrounding rock, in the stope $41^{\#}$, 3250 meters section, Yangla copper deposit, Yunnan, China.

\begin{tabular}{|c|c|c|c|c|c|c|c|c|c|c|c|c|c|c|c|}
\hline \multirow{2}{*}{ Sample no. } & \multirow{2}{*}{ Rock types } & \multirow{2}{*}{ Sample length } & \multicolumn{12}{|c|}{ Metallogenic element contents (ppm) } & \multirow{2}{*}{ Reference } \\
\hline & & & $\mathrm{Cu}$ & $\mathrm{Pb}$ & $\mathrm{Zn}$ & $\mathrm{Au}$ & $\mathrm{Ag}$ & Mo & $\mathrm{W}$ & $\mathrm{Sn}$ & $\mathrm{Bi}$ & $\mathrm{Ge}$ & $\mathrm{Ga}$ & $\mathrm{Cd}$ & \\
\hline $3250-41 \#-1^{\#}$ & \multirow{3}{*}{ Sericite sandy-slate } & $1.5 \mathrm{~m}$ & 8409 & 114 & 190 & 0.24 & 3.0 & 22 & 351 & 33 & 170 & 3.1 & 14 & 0.8 & \multirow{6}{*}[23]{} \\
\hline $3250-41 \#-2^{\#}$ & & $1.5 \mathrm{~m}$ & 5045 & 63 & 131 & 0.12 & 2.0 & 16 & 566 & 31 & 104 & 1.9 & 14 & 0.7 & \\
\hline $3250-41 \#-3^{\#}$ & & $1.8 \mathrm{~m}$ & 5209 & 242 & 174 & 0.32 & 6.0 & 17 & 1103 & 23 & 375 & 1.9 & 12 & 1.0 & \\
\hline $3250-41 \#-4^{\#}$ & \multirow{2}{*}{ Granite porphyry } & $1.5 \mathrm{~m}$ & 12170 & 57 & 241 & 0.12 & 6.0 & 3.3 & 295 & 14 & 61 & 2.1 & 13 & 1.6 & \\
\hline $3250-41 \#-5^{\#}$ & & $1.5 \mathrm{~m}$ & 2019 & 66 & 86 & 0.1 & 2.0 & 10 & 79 & 14 & 27 & 1.5 & 14 & 0.8 & \\
\hline $3250-41 \#-6^{\#}$ & Sericite sandy-slate & $2.0 \mathrm{~m}$ & 4508 & 138 & 199 & 0.31 & 4.0 & 8.7 & 85 & 25 & 178 & 1.8 & 12 & 1.2 & \\
\hline
\end{tabular}

minerals (pyrite and chalcopyrite) are mainly related to silicification and carbonation, especially the silicification (quartz vein) was stronger, and the $\mathrm{Cu}$ and $\mathrm{Fe}$ mineralization were more intensive (Figures 7(l)-7(o)). The $\mathrm{Cu}$ and Fe mineralization are positive correlation with the alternations of silicification and carbonation in the GPs. The $\mathrm{Cu}$ contents of the GPs in the Linong ore block, YCD, range from 0.2019 to 1.217 wt. $\%$ with an average of 0.535 wt. $\%$; the $\mathrm{Au}$ and $\mathrm{Ag}$ at $>0.1 \mathrm{ppm}$ and $>1 \mathrm{ppm}$, respectively (Table 2 ).

\section{Samples and Methods}

3.1. Zircon $U-P b$ Dating. Three GP samples were collected from the tunnel in the $3250 \mathrm{~m}$-deep section of the Linong ore block, YCD. The samples were crushed, and single zircons were separated using flotation and electromagnetic methods. Next, zircons with good crystal shape, transparency, and color were selected manually using a binocular microscope. These zircons were attached to an epoxy resin surface and were then polished and photographed under transmitted and reflected light. Zircons with good crystal characteristics were selected for cathodoluminescence (CL) photography, and the CL photographs were used as the basis for selecting typical magmatic zircons for laser ablation inductively coupled plasma mass spectrometry (LA-ICPMS) dating analysis. The CL imaging of zircons was conducted in the electron probe analysis room of Northwest University in Xi'an. Zircon U-Pb dating was performed at the same institution, although in the LA-ICP-MS room of the State Key Laboratory of Continental Dynamics. The analysis employed a 7500a ICP-MS instrument (Agilent Technologies, Inc., Lexington, Massachusetts. USA) and a 


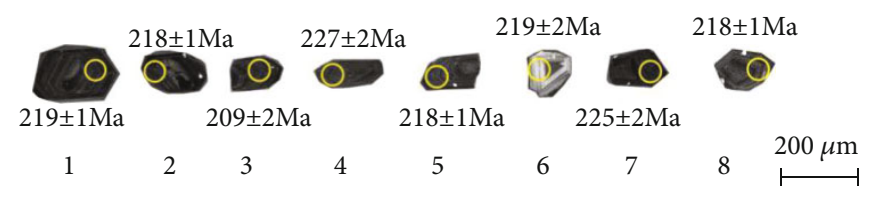

(a)

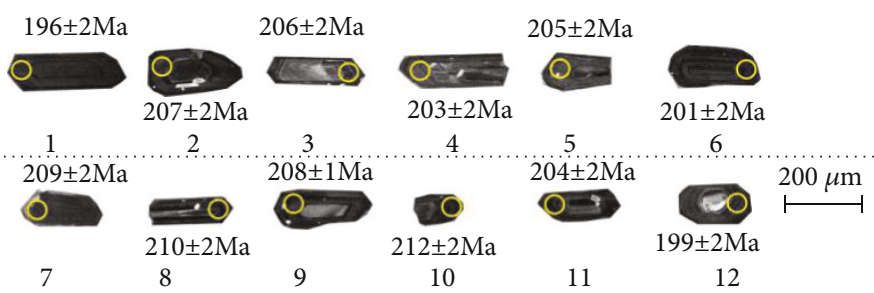

(b)

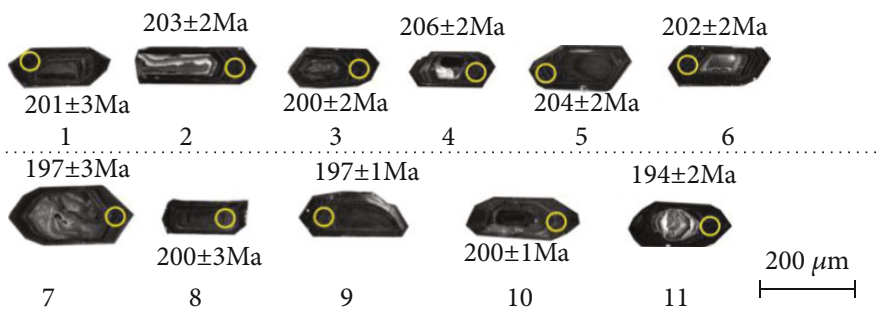

(c)

Figure 8: The zircon cathodoluminescence (CL) images ((a) 3250-41Lb1, (b) 3250-41Lb2, and (c) 45-R4) from the granite porphyries in Yangla copper deposit, Yunnan, China.

UP193 SS laser ablation system (New Wave Research, Inc., Fremont, California, USA). A spot diameter of $36 \mu \mathrm{m}$ was used for the zircon $\mathrm{U}-\mathrm{Pb}$ dating, and the international zircon standards 91500 and NIST SRM610 were used as the external standard material. According to the external standard calibration method, a sample was measured at every four to five sample analysis points to ensure similar instrument conditions for both the standard material and the sample. Glitter software (version 4.4.1) was used for data processing of the samples, Andersen's method was used for common Pb correction (Andersen, 2002) [38], and Isoplot software (version 3.23) was used for age calculations and concordia diagram plotting (Ludwing, 2012) [39]. The error criterion during testing was $1 \sigma$. Details of the experimental process are presented in Black et al. (2004) [40].

3.2. Testing of Major and Trace Elements. Eight GP samples were collected from Stope No. 41 at the 3250-m- and 3275m-deep sections of the tunnel of the Linong ore block. Analytical testing of the major and trace elements and REEs of the samples was conducted at the Northwest Geological Testing Center, a laboratory of the China Nonferrous Metal Mining Group Co., Ltd. The major elements were analyzed using the IRAS ADVANTAGE inductively coupled plasma atomic emission spectrometer (ICP-AES) with an analytical precision of $\geq 3 \%$. The trace elements and REEs were analyzed using an X-7 ICP-MS instrument with an analytical precision of $\geq 10 \%$. The specific analytical process of the trace elements was conducted following the processes reported by Qi et al. (2000) [41].

\section{Results}

4.1. Crystallization Age. Single zircons were selected from three objects-GP samples 3250-41Lb1, 3250-41Lb2, and 45$\mathrm{R} 4$. One point on each zircon was measured. The CL images of the zircons from the three samples are dark gray in color and exhibit clear crystal shapes of long or short columns approximately $100-300 \mu \mathrm{m}$ in length. The color of the zircons was quite dark, resulting in relatively weak zircon CL. The zircons are highly automorphic. Magmatic oscillatory belt structures (growth zones) were clearly developed (Figure 8), which indicates that the zircons are typical magmatic zircons [42]. Data of the LA-ICP-MS zircon U-Pb dating of the GPs are listed in Table 3.

4.1.1. Sample 3250-41Lb1. The Th, $\mathrm{U}$, and $\mathrm{Pb}$ values of the zircons are 76.9-567 ppm, 228-2010 ppm, and 11.57$96.8 \mathrm{ppm}$, respectively (Table 3 ). The $\mathrm{Th} / \mathrm{U}$ values are $0.2-$ 0.3 , with an average value of 0.25 . Significant positive correlations are present between the zircon $U$ versus Th and $\mathrm{U}$ versus $\mathrm{Pb}$ (Figure 9) as geochemical characteristics of magmatic zircons [43]. The ${ }^{206} \mathrm{~Pb} /{ }^{238} \mathrm{U}$ ages of the eight zircons are $209 \pm 2-227 \pm 2 \mathrm{Ma}$, with a weighted average age of $218.6 \pm 2.9 \mathrm{Ma}, \mathrm{MSWD}=7.5(n=8)$. All of the sample points on the zircon ${ }^{206} \mathrm{~Pb} /{ }^{238} \mathrm{U}_{-}{ }^{207} \mathrm{~Pb} /{ }^{235} \mathrm{U}$ concordia diagram fall on or near the harmonic line (Figure 10). Good correspondence was noted among the ${ }^{206} \mathrm{~Pb} /{ }^{238} \mathrm{U}$ ages of the eight measurement points, which formed a relatively concentrated zircon group with a harmonic age of $213 \pm 15 \mathrm{Ma}$, MSWD $=1.9(n=8)$. This result is consistent with the 


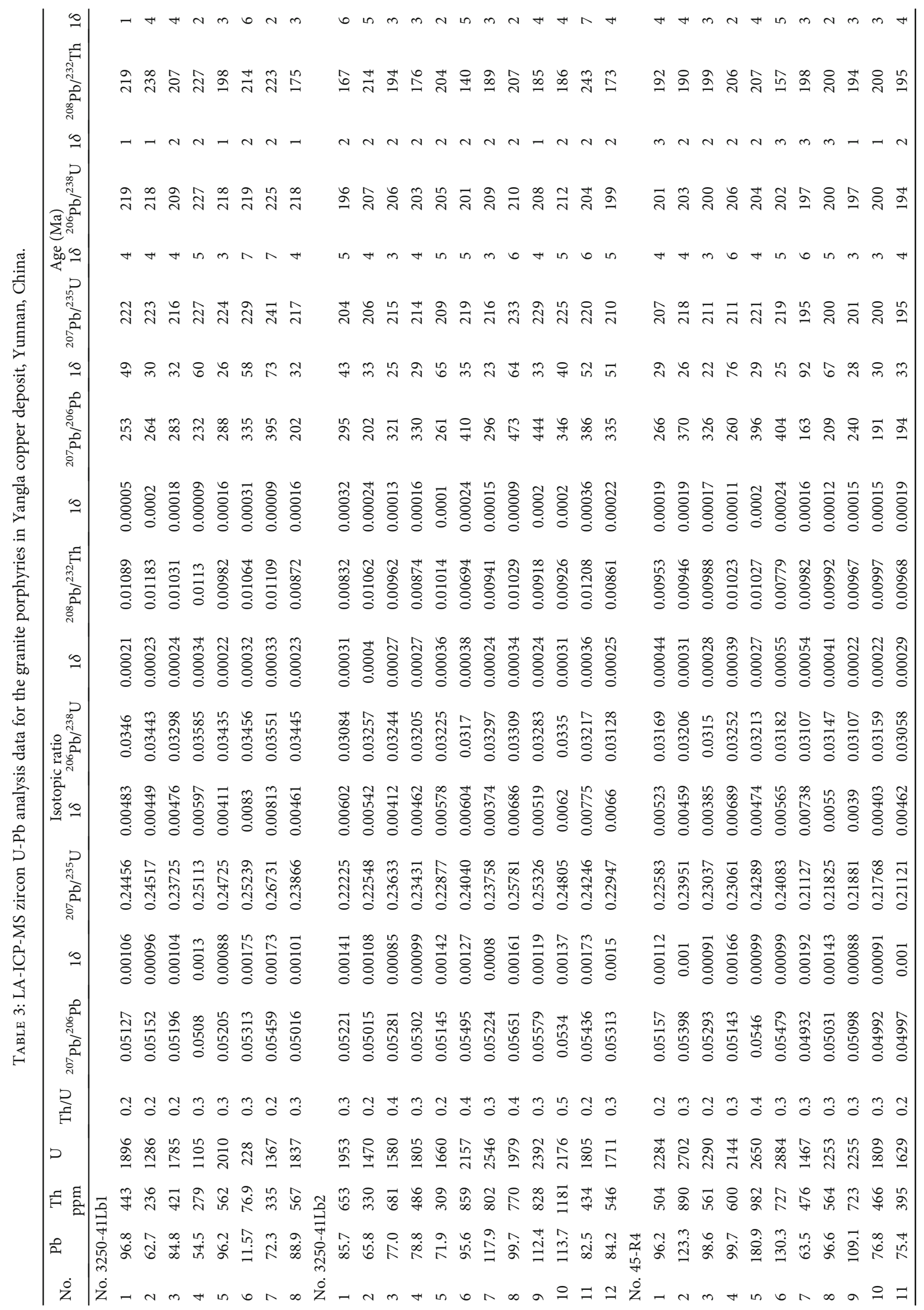



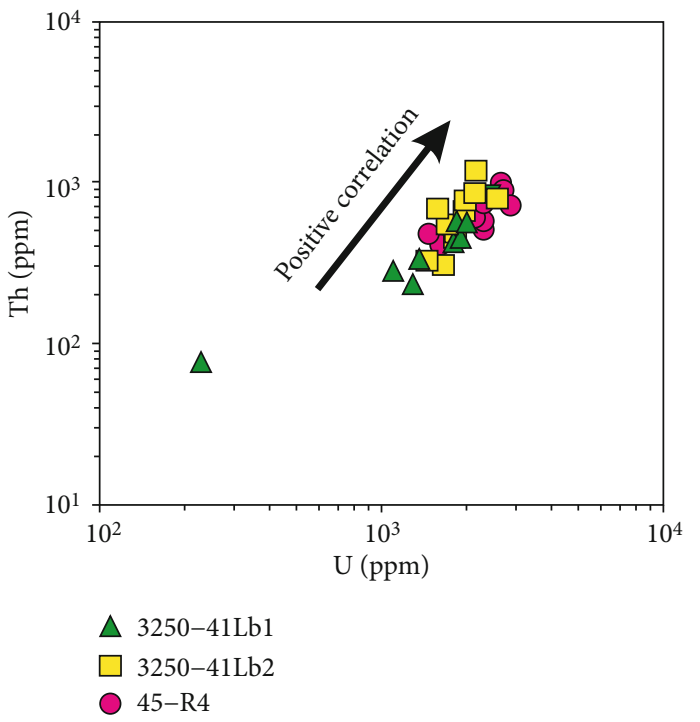

(a)

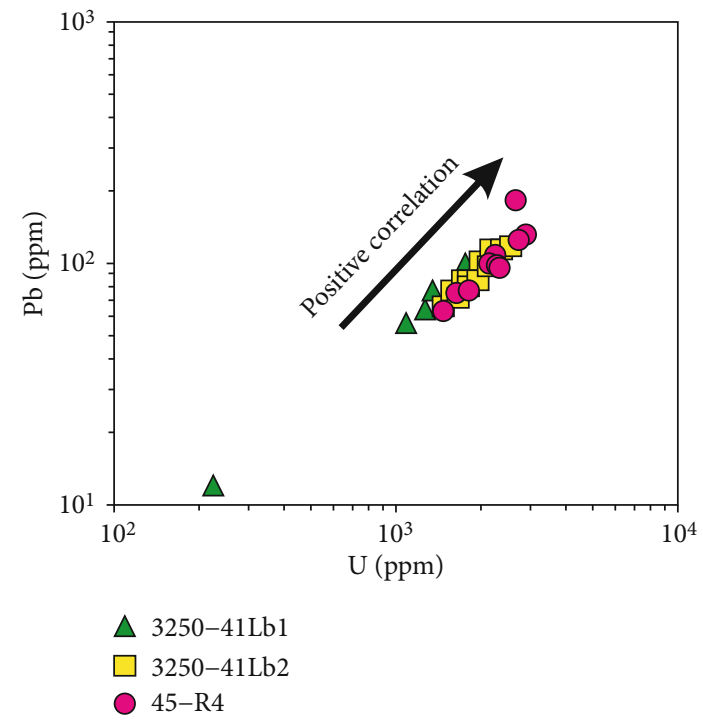

(b)

FIGURE 9: The covariant diagram of Th-U (a) and $\mathrm{Pb}-\mathrm{U}$ (b) zircons from the granite porphyries in Yangla copper deposit, Yunnan, China.

weighted average age, which indicates that the harmonic age of $213 \pm 15 \mathrm{Ma}$ is the replacement age of the GP.

4.1.2. Sample 3250-41Lb2. The values of the zircon Th, U, and $\mathrm{Pb}$ are 309-1181 ppm, 1470-2546 ppm, and 65.8-117.9 ppm, respectively (Table 3 ). The $\mathrm{Th} / \mathrm{U}$ values are $0.2-0.5$, with an average value of 0.32 . Significant positive correlation is present between the zircon $\mathrm{U}$ versus Th and $\mathrm{U}$ versus $\mathrm{Pb}$ values, demonstrating geochemical characteristics of magmatic zircons (Figure 9) [43]. The ${ }^{206} \mathrm{~Pb} /{ }^{238} \mathrm{U}$ ages of the 12 zircons are $196 \pm 2-212 \pm 2 \mathrm{Ma}$ with a weighted average age of $205.6 \pm 2.8 \mathrm{Ma}, \mathrm{MSWD}=6.0 \quad(n=12)$. All of the sample points plotted fall on or near the harmonic line on the zircon ${ }^{206} \mathrm{~Pb} /{ }^{238} \mathrm{U}-{ }^{207} \mathrm{~Pb} /{ }^{235} \mathrm{U}$ concordia diagram (Figure 10 ), indicating good correspondence between the ${ }^{206} \mathrm{~Pb} /{ }^{238} \mathrm{U}$ ages of the 12 measurement points. The harmonic age of $198.4 \pm$ 8.6 Ma, MSWD (Mean Squared Weighted Deviates) $=3.7$ $(n=12)$ is essentially consistent with the weighted average age and is likely the GP's replacement age.

4.1.3. Sample 45-R4. The $\mathrm{Th}, \mathrm{U}$, and $\mathrm{Pb}$ values of the zircons are $395-982 \mathrm{ppm}, 1467-2884 \mathrm{ppm}$, and $63.50-180.90 \mathrm{ppm}$, respectively (Table 3 ). The $\mathrm{Th} / \mathrm{U}$ values are in the range of $0.2-0.4$, with an average value of 0.28 . Significant positive correlation is present between the $\mathrm{U}-\mathrm{Th}$ and $\mathrm{U}-\mathrm{Pb}$ values of the zircons, indicating the geochemical characteristics of magmatic zircons (Figure 9) [43]. The ${ }^{206} \mathrm{~Pb} /{ }^{238} \mathrm{U}$ ages of the 11 zircons are $194 \pm 2-206 \pm 2 \mathrm{Ma}$, and the weighted average age is $199.7 \pm 2.1 \mathrm{Ma}$, MSWD $=3.4(n=11)$. All of the sample points on the zircon ${ }^{206} \mathrm{~Pb} /{ }^{238} \mathrm{U}-{ }^{207} \mathrm{~Pb} /{ }^{235} \mathrm{U}$ concordia diagram fall on or near the harmonic line (Figure 10). Good correspondence was noted among the ${ }^{206} \mathrm{~Pb} /{ }^{238} \mathrm{U}$ ages of the 11 measurement points, which formed a relatively concentrated zircon group with a harmonic age of $195.3 \pm 6.4$ $\mathrm{Ma}, \mathrm{MSWD}=3.3(n=11)$. The harmonic age is essentially consistent with the weighted average age and is likely the GP's replacement age.

4.2. Major Elements. The major element data of the GPs are listed in Table 4 . The loss on ignition (LOI) values are high (>4.23 wt.\%), suggesting that these rocks might have undergone low-grade hydrothermal alteration during postmagmatic events [44-46]. Therefore, the effects of hydrothermal alteration on the related elements are discussed subsequently in Section 5.1 .

The $\mathrm{SiO}_{2}$-oxide scatter diagram does not show obvious linear correlation between the $\mathrm{SiO}_{2}$ and other oxides of the GPs (Figure 11), which indicates insignificant fractional crystallization during the diagenetic process. In comparison with the granodiorites of the Yangla mining district, the GPs are relatively rich in $\mathrm{SiO}_{2}$ and $\mathrm{Fe}_{2} \mathrm{O}_{3}{ }^{\mathrm{T}}$ but are deficient in $\mathrm{K}_{2} \mathrm{O}, \mathrm{Na}_{2} \mathrm{O}$, and $\mathrm{P}_{2} \mathrm{O}_{5}$. The GPs plots concentrated in the granodiorite region in the $\mathrm{SiO}_{2}-\left(\mathrm{Na}_{2} \mathrm{O}+\mathrm{K}_{2} \mathrm{O}\right)$ diagram (Figure 12(a)). The $\mathrm{K}_{2} \mathrm{O}$ values of the GPs are higher than those of $\mathrm{Na}_{2} \mathrm{O}$, with high $\mathrm{K}_{2} \mathrm{O} / \mathrm{Na}_{2} \mathrm{O}$ ratios. All plots on the $\mathrm{SiO}_{2}-\mathrm{K}_{2} \mathrm{O}$ diagram (Figure 12(b)) are within the range of the calc-alkaline series. The Rittmann index $(\delta)$ of the GPs, at $0.13-0.15(<3.30)$ with an average value of 0.14 (Table 4 ), also confirms that the GPs belong to calc-alkaline series rocks. The alkalinity (AR) is $1.23-1.25$, and the aluminum saturation index $(\mathrm{A} / \mathrm{CNK})$ is $1.22-1.78$. The GPs plots concentrated in the calc-alkaline series on the $\mathrm{SiO}_{2}-\mathrm{AR}$ diagram (Figure 12(c)) also indicate calc-alkaline series characteristics. The influence of low-grade alteration such as silicification and carbonation potentially caused the GPs plots to be relatively dispersed on the $\mathrm{A} / \mathrm{CNK}-\mathrm{A} / \mathrm{NK}$ diagram (Figure 12(d)). Nevertheless, all are located within the field of the peraluminous series.

4.3. Trace Elements. The general characteristics of variations in the trace element values for eight GP samples are similar 

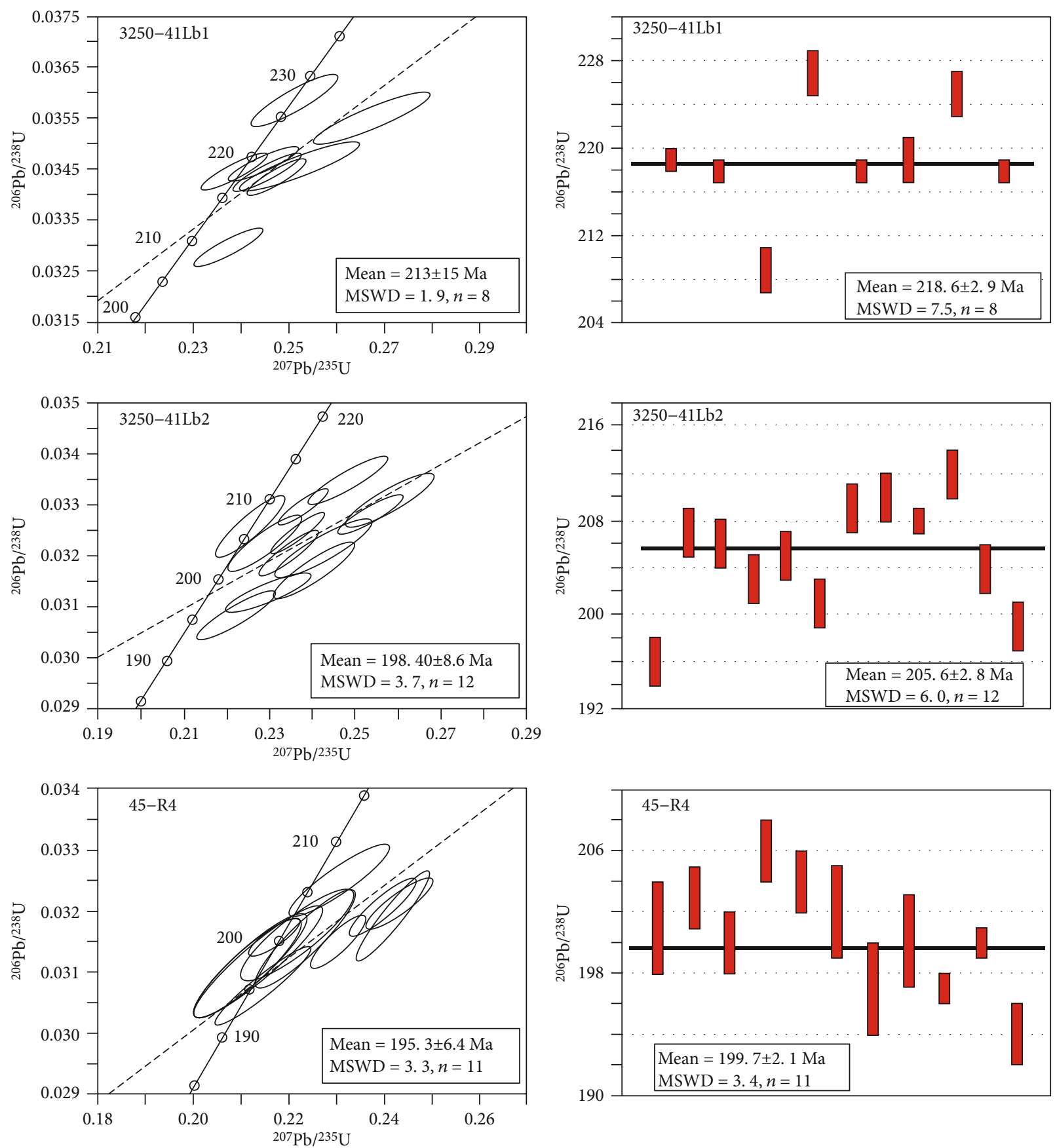

Figure 10: LA-ICP-MS zircon U-Pb concordia diagram of the granite porphyries in Yangla copper deposit, Yunnan, China.

(Table 5). The values of the transition elements $\mathrm{Sc}, \mathrm{V}, \mathrm{Cr}, \mathrm{Co}$, and $\mathrm{Ni}$ are relatively low. The primitive mantle-normalized spider diagram (Figure 13(a)) shows that the GPs are rich in large-ion lithophile elements (LILEs) such as Rb, Ba, Th, $\mathrm{U}, \mathrm{K}$, and La. Specifically, the $\mathrm{Ba}$ is relatively depleted compared with the $\mathrm{Rb}$, Th, and $\mathrm{U}$; $\mathrm{Sr}$ shows the greatest depletion relative to the LILEs. High field strength elements (HFSEs) such as Ta, Nb, Ce, Zr, Hf, and Ti are depleted compared with the LILEs; Ti shows the greatest depletion. The GPs are significantly rich in $\mathrm{Pb}$ but are deficient and slightly deficient in $\mathrm{P}$ and $\mathrm{Ti}$, respectively. In addition, the values of metallogenic elements show the trend of $\mathrm{Cu}>\mathrm{Pb}>\mathrm{Zn}, \mathrm{Cu}$ in the highest abundance. In the relationship diagram between $\mathrm{SiO}_{2}$ and trace elements, $\mathrm{SiO}_{2}$ is negatively correlated with $\mathrm{Cu}$ (Figure 14(a)), Pb (Figure 14(e)), and Y (Figure 14(f)) but positively correlated with Cs (Figure 14(b)), Ta (Figure 14(c)), and U (Figure 14(d)).

4.4. REEs. The GPs have relatively high REE contents (Table 6) including $\Sigma$ REE values of $50.41 \mathrm{ppm}-127.27 \mathrm{ppm}$, light rare earth element (LREE) values of $41.61 \mathrm{ppm}-$ $116.23 \mathrm{ppm}$, heavy rare earth element (HREE) values of $8.80 \mathrm{ppm}-15.40 \mathrm{ppm}$, and LREE/HREE ratios of 4.73-10.54, all of which indicate LREE-enriched GPs. The $\mathrm{La}_{\mathrm{N}} / \mathrm{Yb}_{\mathrm{N}}$ ratio 


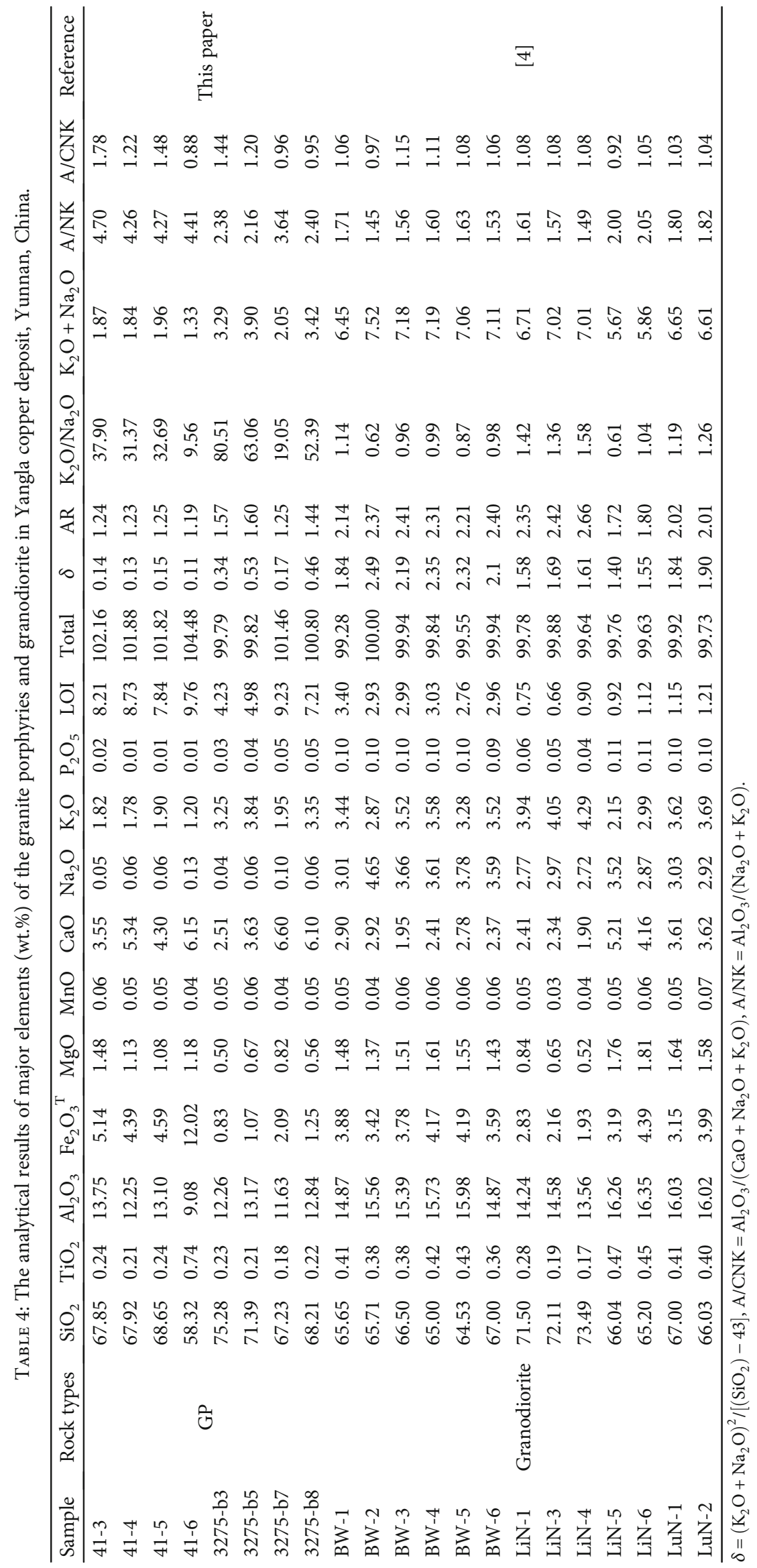




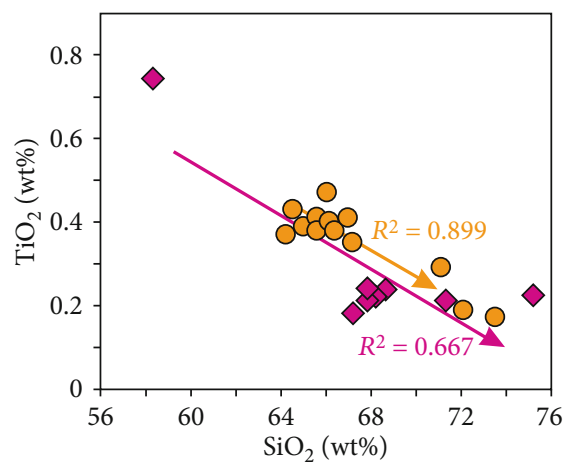

$\diamond$ Granite porphyry (this paper)

O Granodiorite (Zhu et al., 2011)

(a)

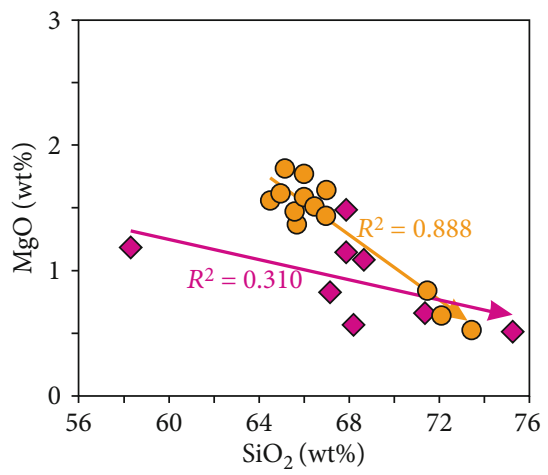

Granite porphyry (this paper)

Granodiorite (Zhu et al., 2011)

(d)

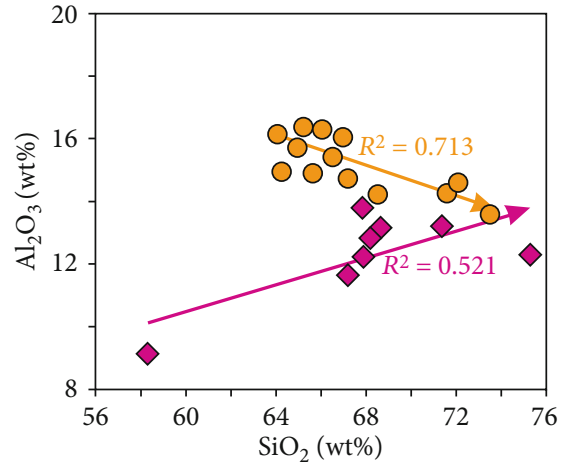

Granite porphyry (this paper)

O Granodiorite (Zhu et al., 2011)

(b)

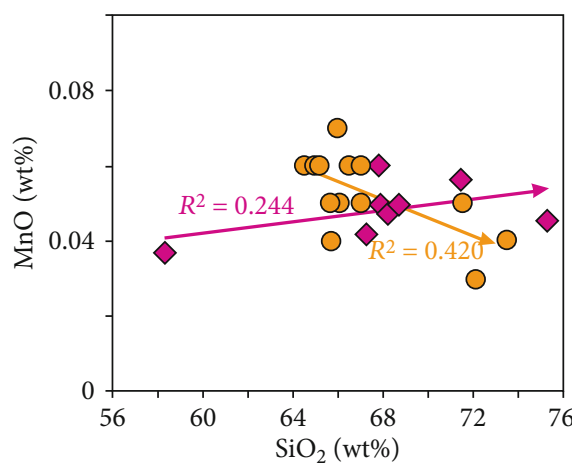

Granite porphyry (this paper)

O Granodiorite (Zhu et al., 2011)

(e)

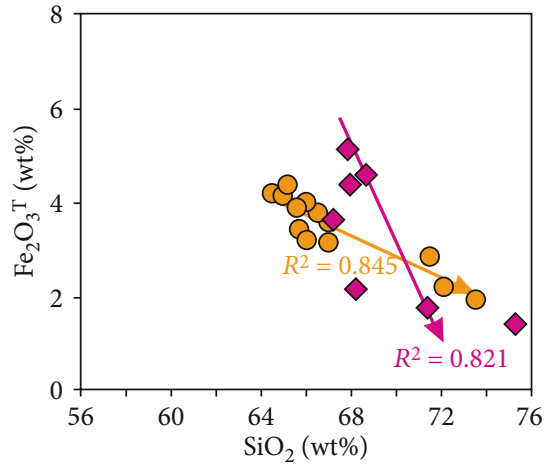

$\checkmark$ Granite porphyry (this paper)

O Granodiorite (Zhu et al., 2011)

(c)

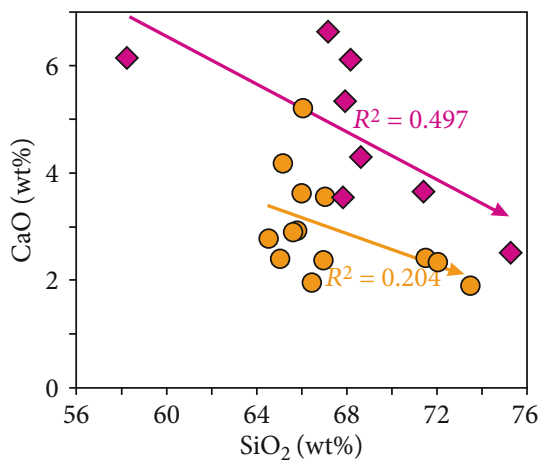

Granite porphyry (this paper)

O Granodiorite (Zhu et al., 2011)

(f)

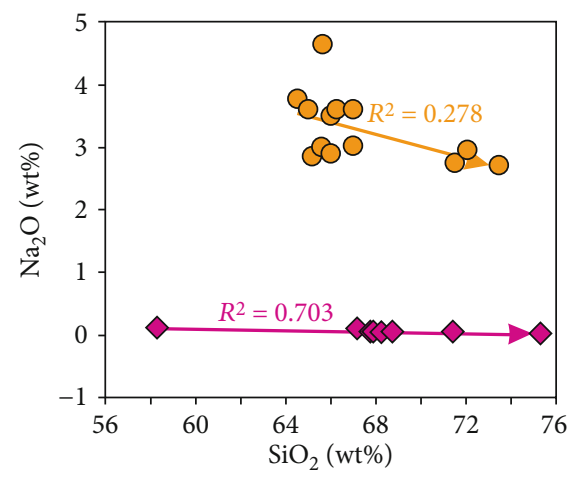

Granite porphyry (this paper)

O Granodiorite (Zhu et al., 2011)

(g)

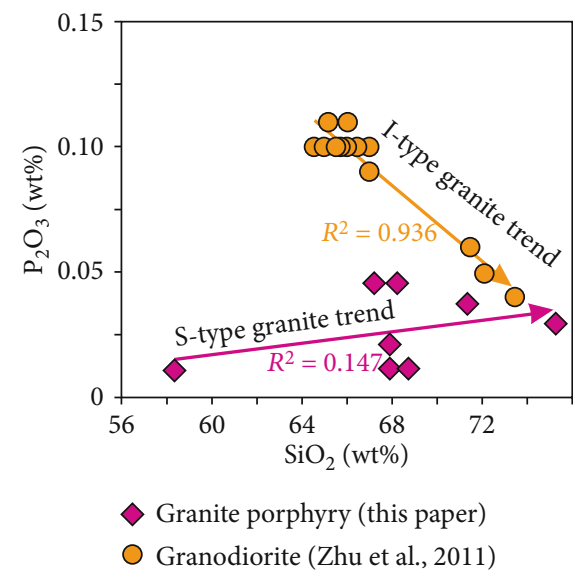

(h)

FIGURE 11: Variation of major elements with $\mathrm{SiO}_{2}$ of the granite porphyries and granodiorite in Yangla copper deposit, Yunnan, China ((h) after Li et al., 2007 [60]).

is 3.69-12.27, revealing a high degree of differentiation between the LREEs and HREEs. The $\delta$ Eu and $\delta \mathrm{Ce}$ values of the GPs are 0.53-0.86 and 0.79-0.98, indicating weak and slightly weak negative anomalies, respectively. The distribution patterns on the chondrite-normalized REE plots are right-trending with weak negative $\mathrm{Eu}$ anomalies (Figure 15(a)).

\section{Discussion}

5.1. Evaluation of Alteration Effects. Studies have show that the extensive alteration effects occurred during the metallogenic process of the magmatic-hydrothermal deposit and its mineralization often related to granitoid intrusions [44, 46]. Previous research indicates the existence of mainly (i) 


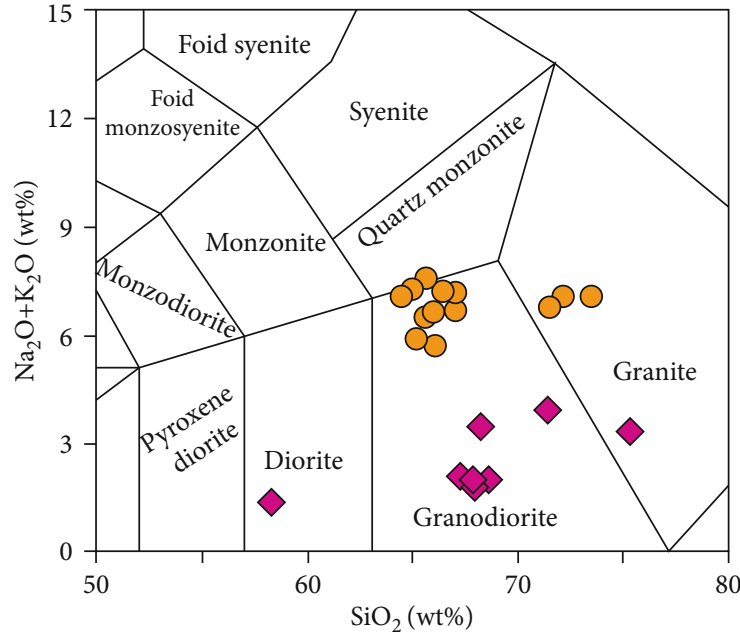

Granite porphyry (this paper)

Granodiorite (Zhu et al., 2011)

(a)

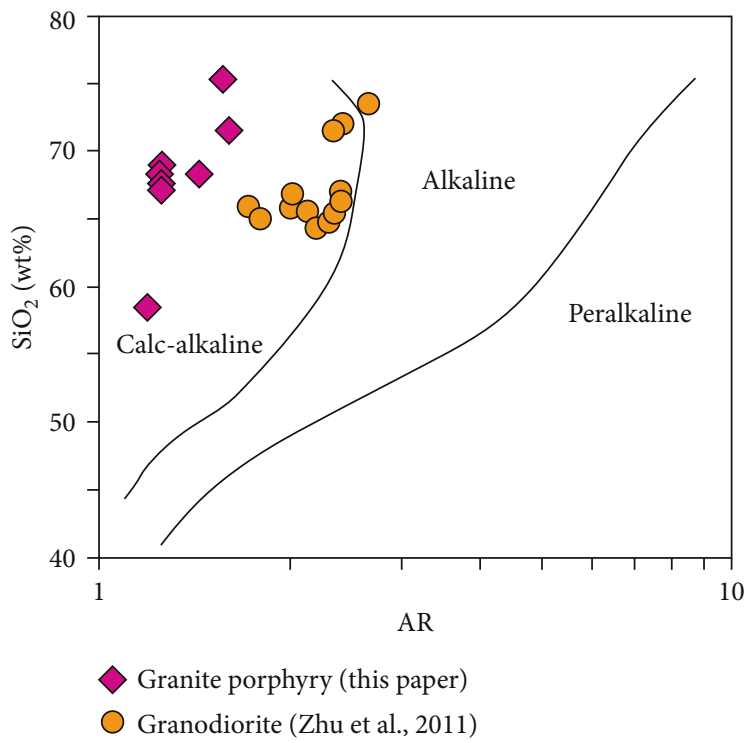

(c)

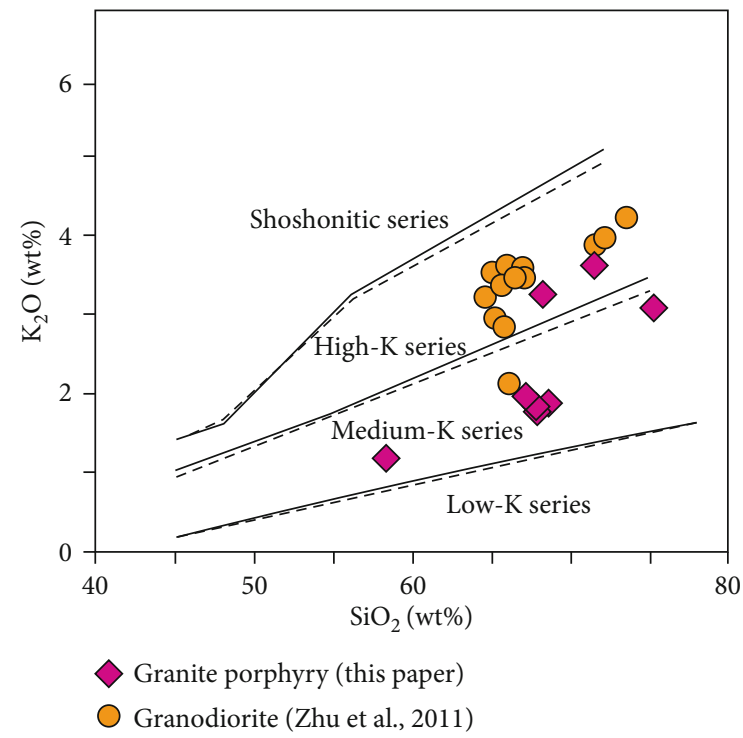

(b)

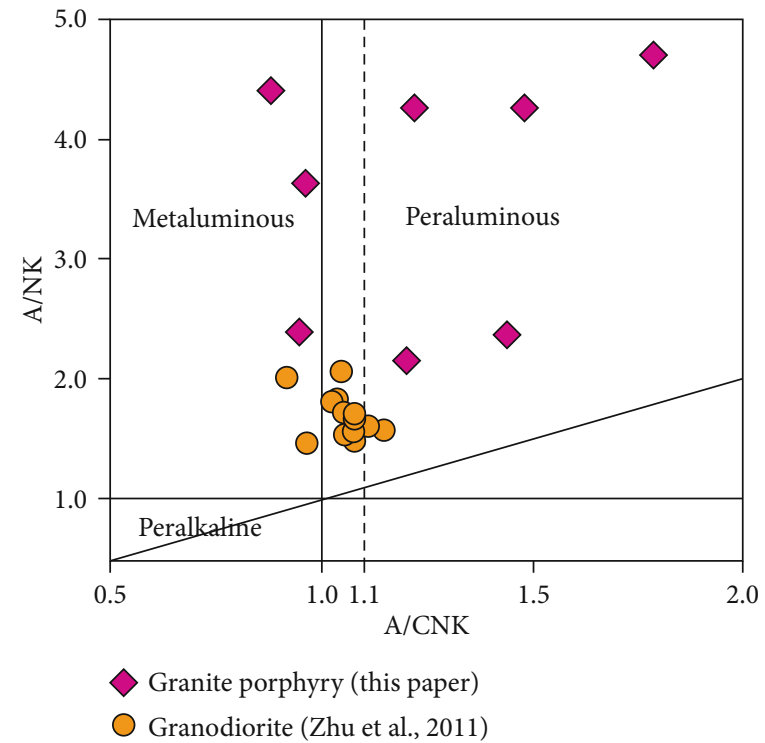

(d)

FIGURE 12: Major element diagrams of the granite porphyries and granodiorite in Yangla copper deposit, Yunnan, China. (a) TAS diagrams after Middlemost, 1994 [73]. (b) $\mathrm{SiO}_{2}-\mathrm{K}_{2} \mathrm{O}$ diagrams after Morrison, 1980, Rickwood, 1989, and Rollinson, 1993 [74-76]. (c) SiO 2 -AR diagrams after Wright, 1969 [77]. (d) A/NK-A/CNK diagrams after Maniar and Piccoli, 1989 [78].

potassic, (ii) propylitic, (iii) phyllic, and (iv) argillic alterations as hydrothermal alteration processes of the orebearing porphyry dikes in ore deposit [47, 48]. (i) The potassic alteration developed mainly K-feldspar and finegrained hydrothermal biotite, which were controlled strictly by the high-temperature single-phase fluid (initial fluid) [49]. (ii) The propylitic alteration is characterized by abundant hydrous minerals such as quartz + epidote + chlorite + pyrite \pm actinolite \pm chalcopyrite veins, which were limited by the fluid containing a mixture of magmatic brine and the circulating groundwater heated by the intrusion [50]. (iii) The phyllic alteration is represented by sericite and substantial quartz, which was affected by the low-temperature liquid phase fluid that directly separated from the magma
[51]. (iv) The argillic alteration is characterized by kaolinite and illite and overlies the phyllic alteration of Stage (iii). The alteration in this stage was influenced mainly by a lowdensity gas phase originating from the differentiation of the high-temperature single phase fluid in Stage (i) and a lowtemperature liquid phase fluid originating from the lowtemperature liquid phase fluid in Stage (iii) [48].

In the GPs of the YCD, only small amounts of sericite, chlorite, and kaolinite are overlain and filled with the surface of plagioclase and biotite phenocrysts (Figures 5 and 6) and small amounts of secondary veined quartz-calcite and veined-disseminated pyrite and chalcopyrite (Figure 7), which based on the results of the ore field observation, thin-section petrographic observation, and the LOI values > 


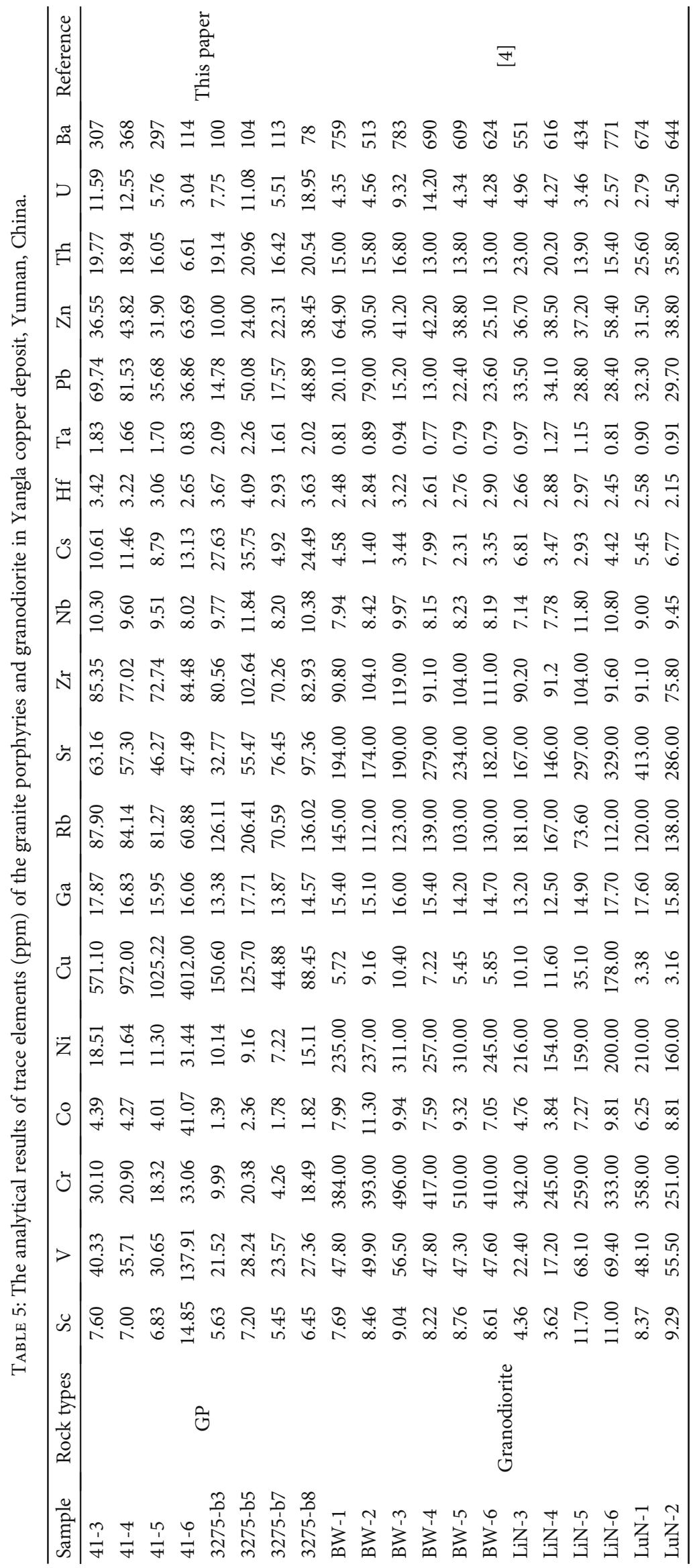




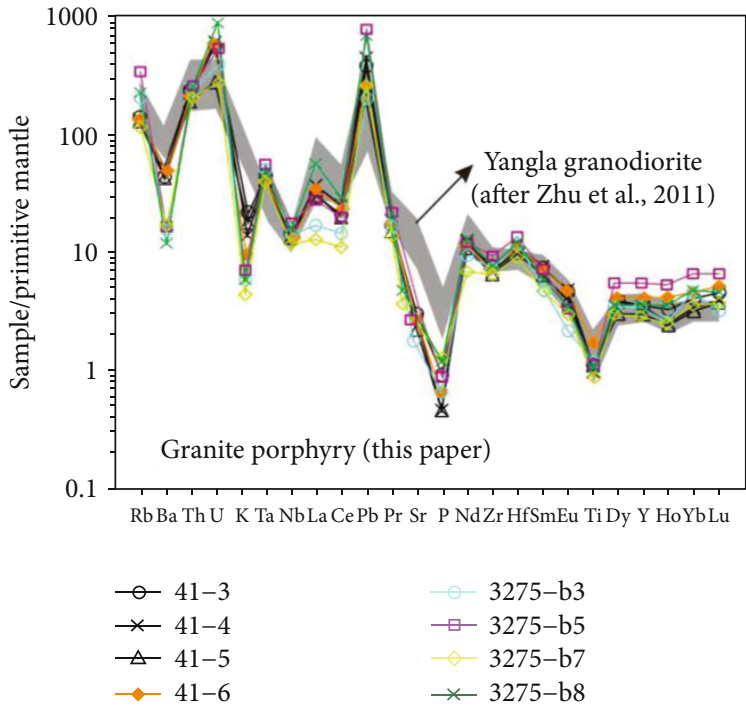

(a)

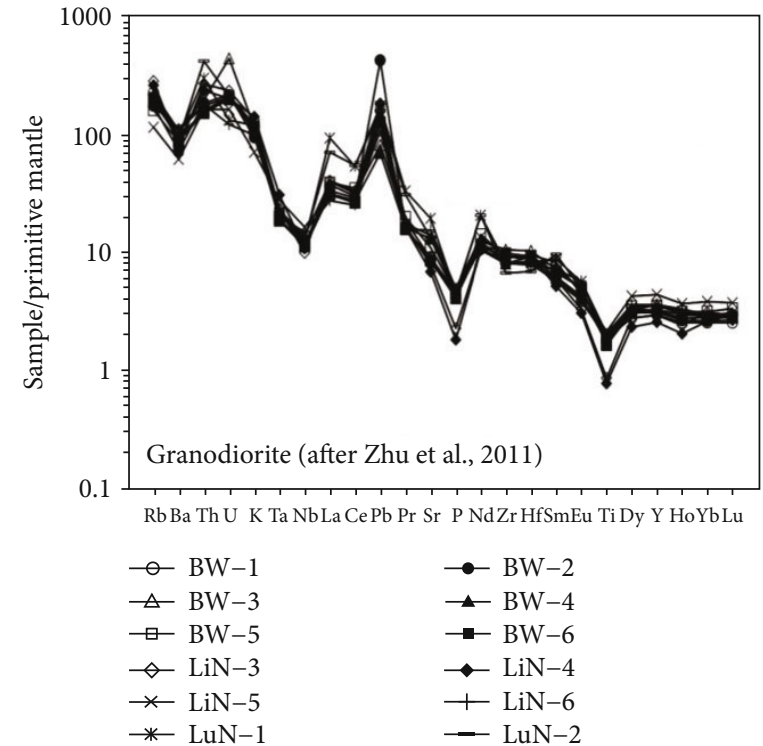

(b)

Figure 13: Primitive mantle-normalized spider diagram of the granite porphyries and granodiorite in Yangla copper deposit, Yunnan, China (after Sun and Mcdonough, 1989 [79]).

4.23 wt.\% (Table 4). These features of aforementioned indicated a few of the GP samples could have undergone minor hydrothermal alteration but there were absent of the aforementioned typical altered mineral assemblages. Because the hydrothermal fluids slightly affected the alteration system, medium-temperature-medium salinity and lowtemperature-low salinity ore-forming fluids might be indicated, although such fluids cause only weak hydrothermal alteration in GP dikes [52]. Only a few altered minerals are developed, including minor sericite, chlorite, and kaolinite as well as a few secondary quartz, calcite, pyrite, and chalcopyrite [52]. Therefore, we can roughly speculate that the GPs underwent low-grade hydrothermal alteration as evidenced by the altered mineralogy and hydrothermal fluids. This process might not be related to the evidence forming the basis of discussion on the major and trace elements in this study.

Previous studies also have shown that the HFSEs, REEs, and transition elements (e.g., Sc, V, Zr, Nb, Ta, and Hf) are commonly immobile and are unaffected by hydrothermal alteration [44, 46, 53, 54]. Some elements such as Ti, Fe, and $\mathrm{P}$ are not transported by hydrothermal alteration [53], whereas $\mathrm{Ca}, \mathrm{Na}$, and $\mathrm{K}$ as well as LILEs (e.g., Sr, Ba, and $\mathrm{Rb})$ are generally mobile [55]. Thus, the existence of hydrothermal alteration effects can be verified by analyzing the contents of these elements in our samples. In addition, a lack of significant correlation between the ratios of incompatible elements such as $\mathrm{Ba} / \mathrm{La}, \mathrm{Ba} / \mathrm{Rb}$, and $\mathrm{Rb} / \mathrm{Sr}$ of our samples versus the LOI values (Figures 16(a)-16(c)) indicates that these elemental ratios could be a feature of the source region and were unaffected or slightly affected by hydrothermal alteration [46]. The beginning processes of geochemical systems, such as alteration, commonly lead to mass transfers of specific components [56]. For example, hydrothermal alteration can cause potassium anomalies, and the $\mathrm{K}_{2} \mathrm{O}$ concentrations in a hydrothermal deposit increase during alteration [57].
Our GP samples exhibit variable $\mathrm{K}_{2} \mathrm{O}$ concentrations of $1.20-3.84$ wt. $\%$ and high $\mathrm{K}_{2} \mathrm{O} / \mathrm{Na}_{2} \mathrm{O}$ ratios. In correspondence, an obvious negative correlation trend between the $\mathrm{K}_{2} \mathrm{O}$ and LOI values except for sericitization and $\mathrm{K}$ metasomatism (Figure $16(\mathrm{~d})$ ) is expected because the $\mathrm{K}$ rich alterations are related to $\mathrm{K}$-rich water-bearing minerals such as sericite and chlorite. Similarly, an evident correlation trend between the $\mathrm{Sr}$ and $\mathrm{K}_{2} \mathrm{O}$ contents is also expected because $\mathrm{K}_{2} \mathrm{O}$ controls the $\mathrm{Sr}$ content in alteration minerals [46]. Such correlation trends do not appear in the Sr versus $\mathrm{K}_{2} \mathrm{O}$ diagram (Figure 16(f)), which indicates that the $\mathrm{Sr}$ might not have been affected by hydrothermal alteration. Furthermore, the GPs exhibit low $\mathrm{Na}_{2} \mathrm{O}$ concentrations of 0.05-0.13 wt.\%, which might have caused $\mathrm{Na}$ depletion in the plagioclase owing to the aforementioned low-grade hydrothermal alteration. However, the $\mathrm{Na}_{2} \mathrm{O}$ versus LOI diagram (Figure 16(e)) shows a slightly positive correlation, which might be attributed to the formation of small amounts of albite or other Na-rich minerals during hydrothermal alteration. Moreover, no significant difference was noted in the GPs and minor hydrothermal alteration of the Yangla granodiorite plutons (LOI <3.40wt.\%) in a series of diagrams. These diagrams include major elements versus $\mathrm{SiO}_{2}$ diagrams, except $\mathrm{Na}_{2} \mathrm{O}$ versus $\mathrm{SiO}_{2}$ diagrams, in Figure $11(\mathrm{~g}) ; \mathrm{K}_{2} \mathrm{O}+\mathrm{Na}_{2} \mathrm{O}$ versus $\mathrm{SiO}_{2}, \mathrm{~K}_{2} \mathrm{O}$ versus $\mathrm{SiO}_{2}$, and $\mathrm{AR}$ versus $\mathrm{SiO}_{2}$ diagrams, except those for $\mathrm{A} / \mathrm{NK}$ versus $\mathrm{A} / \mathrm{CNK}$ in Figure $12(\mathrm{~d}) ; \mathrm{K}_{2} \mathrm{O} / \mathrm{MgO}, \mathrm{Zr}, \mathrm{Nb}$, and $\mathrm{Y}$ versus $10000 \mathrm{Ga} / \mathrm{Al}$ ACF diagrams in Figure 17; Nb versus $\mathrm{Y}, \mathrm{Ta}$ versus $\mathrm{Yb}, \mathrm{Rb}$ versus $\mathrm{Yb}+\mathrm{Ta}, \mathrm{Rb}$ versus $\mathrm{Y}+\mathrm{Nb}$, and $\mathrm{Rb} / 30$ $\mathrm{Hf}-3 \times$ Ta diagrams in Figure 18; and Ba versus $\mathrm{Sr}, \mathrm{Rb}$ versus $\mathrm{Sr}, \delta \mathrm{Eu}$ versus $\mathrm{SiO}_{2}$, and $\mathrm{La} / \mathrm{Yb}$ versus $\delta \mathrm{Eu}$ diagrams in Figure 19. All of these diagrams indicate similar geochemical characteristics and can be further discussed using $\mathrm{K}-, \mathrm{Na}$-, and Ca-related diagrams with respect to low-grade hydrothermal alteration. 


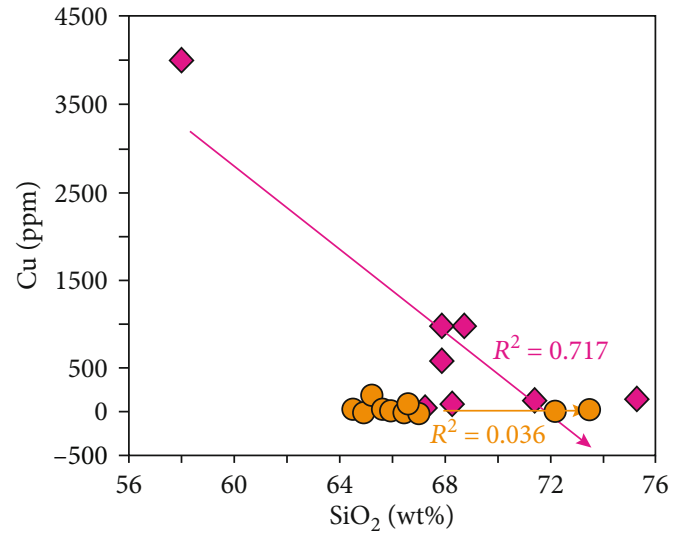

Granite porphyry (this paper)

Granodiorite (Zhu et al., 2011)

(a)

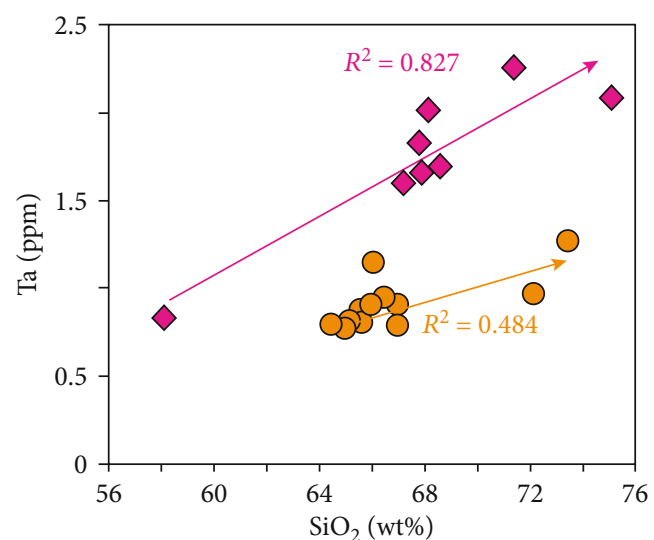

Granite porphyry (this paper)

Granodiorite (Zhu et al., 2011)

(c)

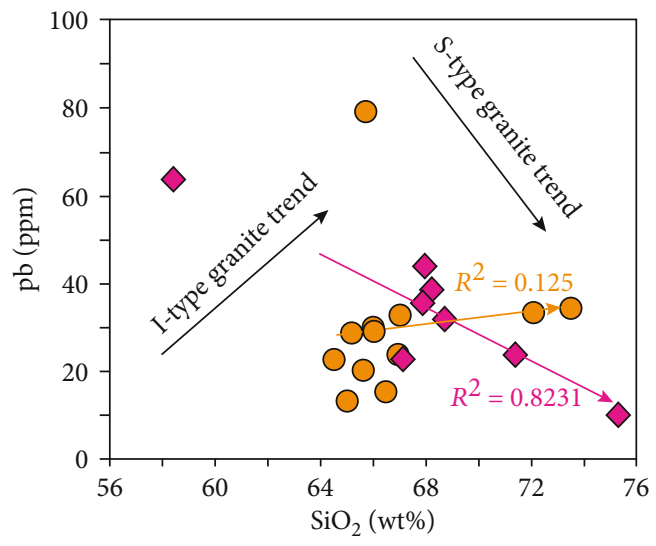

Granite porphyry (this paper)

$\bigcirc$ Granodiorite (Zhu et al., 2011)

(e)

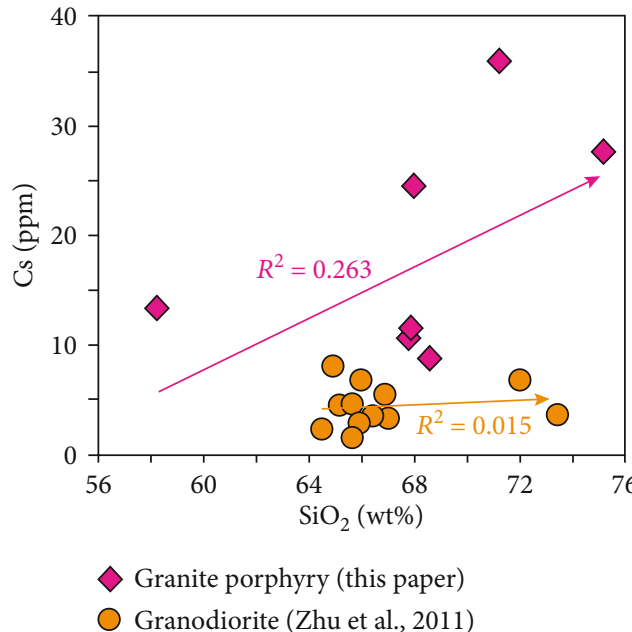

(b)

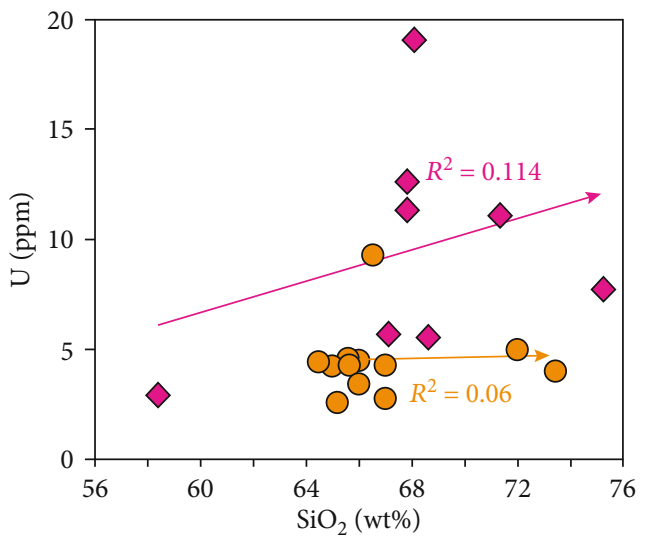

Granite porphyry (this paper)

Granodiorite (Zhu et al., 2011)

(d)

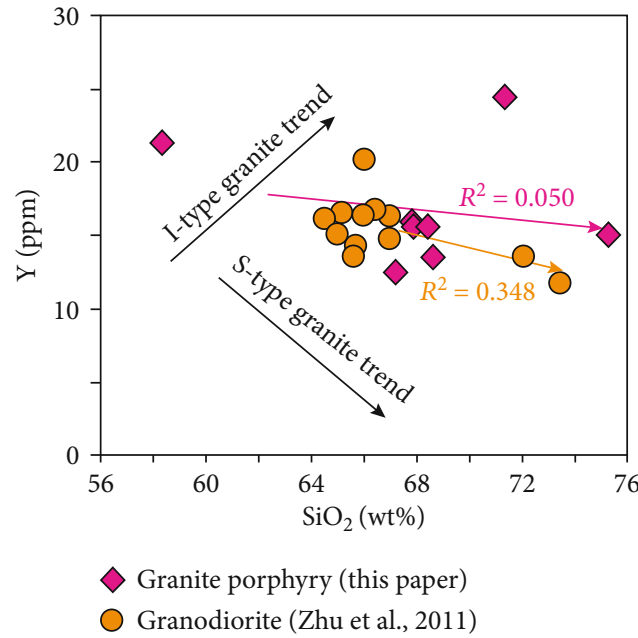

(f)

Figure 14: Continued. 


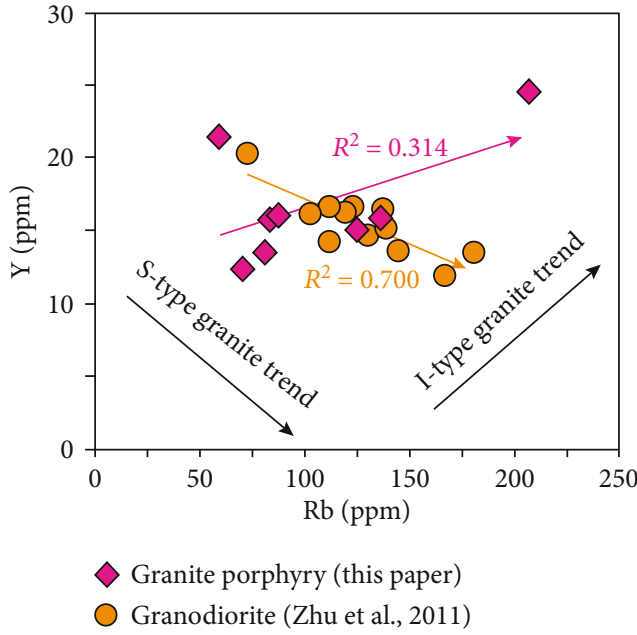

(g)

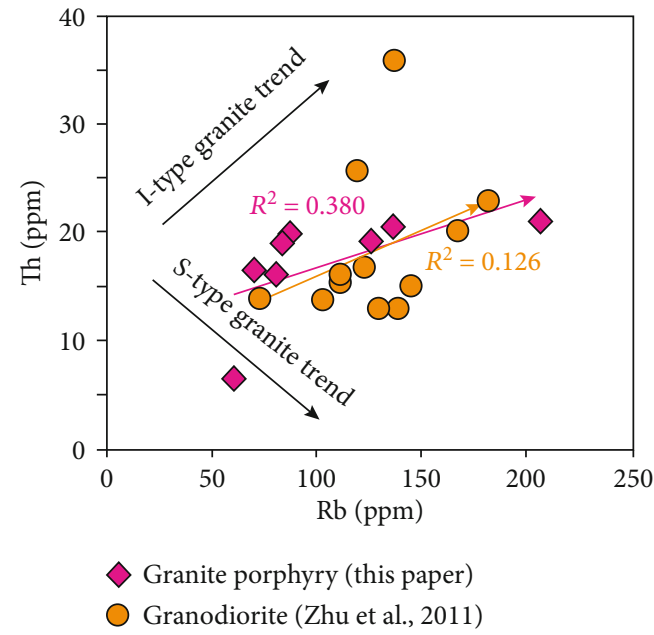

(h)

Figure 14: Variation of trace elements with $\mathrm{SiO}_{2}, \mathrm{Y}$ vs. $\mathrm{Rb}$, and $\mathrm{Th}$ vs. $\mathrm{Rb}$ of the granite porphyries and granodiorite in Yangla copper deposit, Yunnan, China ((e-h) after Li et al., 2007 [60]).

We therefore suggest that the Rb, Sr, Ba, HFSEs, REEs, and transition elements ( $\mathrm{Zr}, \mathrm{Nb}, \mathrm{Ta}$, and $\mathrm{Hf}$ ) can be used to document the petrogenesis and tectonic setting of the GPs to avoid further controversy in this study.

5.2. Comparison with Yangla Granodiorite Plutons. The two zircon $\mathrm{U}-\mathrm{Pb}$ ages of the GPs, $195.3 \pm 6.4 \mathrm{Ma}$ and $198.40 \pm$ $8.6 \mathrm{Ma}$, are significantly younger than the ages of the Yangla granodiorite plutons, at 208-239 Ma, indicating that the GPs formed slightly later. One zircon U-Pb age of a GP, $213 \pm$ $15 \mathrm{Ma}$, clearly falls in the Yangla granodiorite pluton age range (without error ranges). The Yangla granodiorite plutons have only one hornblende Rb-Sr age, at $208 \mathrm{Ma}$, which is younger than the zircon $\mathrm{U}-\mathrm{Pb}$ age of $213 \mathrm{Ma}$; all other zircon $\mathrm{U}-\mathrm{Pb}$ ages are older than $213 \mathrm{Ma}$ (without error ranges) (Table 1). This can be attributed to variation in the minerals and methods. Therefore, even though the GPs and granodiorite plutons have overlapping age ranges, the GPs are significantly younger than the Yangla granodiorite plutons. This also indicates that magmatic activities in the Yangla mining district might have lasted for $\sim 44 \mathrm{Ma}$.

Although the $\mathrm{SiO}_{2}$ values in the GPs and Yangla granodiorites are similar, the effects of mineralization and alteration resulted in the former having lower $\mathrm{Na}_{2} \mathrm{O}, \mathrm{K}_{2} \mathrm{O}$, and $\mathrm{P}_{2} \mathrm{O}_{5}$ values than the latter. However, the GPs have higher $\mathrm{CaO}$, LOI, and $\mathrm{K}_{2} \mathrm{O} / \mathrm{Na}_{2} \mathrm{O}$ ratios (Table 4 , Table 7 , Figure 11) and trace element $(\mathrm{Cu}, \mathrm{Cs}, \mathrm{Ta}, \mathrm{Pb}$, and $\mathrm{U}$ ) values (Table 5 , Table 7, Figure 13, Figure 14) than the granodiorites. This might have been caused by mineralization and alteration to secondary calcite, sericite, and chlorite. The values of other trace elements in the GPs, such as Sc, V, Cr, Co, Ni, Rb, Sr, and $\mathrm{Zr}$, are relatively low. In addition, the GPs are relatively rich in $\mathrm{Cu}, \mathrm{Pb}$, and other metallogenic elements. The $\Sigma \mathrm{REE}$ and LREE values of the GPs are slightly lower than those of the granodiorites. The $\delta \mathrm{Ce}$ values of the GPs and granodiorites exhibit slightly weak negative and positive anomalies, respectively. No significant difference was noted between the $\delta \mathrm{Eu}$ of the GPs and the granodiorites (Table 6 , Table 7 , and Figure 15). This preliminary result indicates that the magmatic source area of the GPs and the Yangla granodiorite plutons might be the same or similar.

5.3. Granite Porphyry Type. Granites are usually classified as I-, S-, A-, or M-types, depending on the properties of the magmatic source areas [58]. I- and S-type granites have similar geochemical characteristics in some elemental properties. I-type granites are crust-mantle mixed-source granites in a collision-related tectonic setting and are composed mainly of quartz, plagioclase, K-feldspar, hornblende, and biotite. They are rich in $\mathrm{Na}\left(\mathrm{Na}_{2} \mathrm{O}>\mathrm{K}_{2} \mathrm{O}\right), \mathrm{Rb}, \mathrm{Th}, \mathrm{U}, \mathrm{P}$, and $\mathrm{A} /$ $\mathrm{CNK}<1.0$ and are deficient in $\mathrm{Nb}, \mathrm{Ta}, \mathrm{Ti}$, and $\mathrm{P}$ [4]. S-type granite is peraluminous granite formed by partial melting and crystallization of crust-source sediments. It is composed mainly of quartz, plagioclase, and biotite, showing enrichment in $\mathrm{K}\left(\mathrm{K}_{2} \mathrm{O}>\mathrm{Na}_{2} \mathrm{O}\right), \mathrm{Rb}, \mathrm{Ta}, \mathrm{U}$, and $\mathrm{A} / \mathrm{CNK}>1.1$ and depletion of $\mathrm{Ba}, \mathrm{Ti}$, and $\mathrm{P}$ [59]. The GPs have higher $\mathrm{K}_{2} \mathrm{O}$ values than $\mathrm{Na}_{2} \mathrm{O}$ (1.20-3.84 wt.\% > 0.05-0.13 wt.\%,) which is consistent with the $\mathrm{K}$-enrichment characteristic of S-type granites (Table 4). According to the Cross, Iddings, Pirrson, and Washington (CIPW) standard minerals calculation results for the GPs and the Yangla granodiorites, the standard corundum and diopside values of S-type granites and I-type granites are $0.59-5.65 \mathrm{wt} . \%$ and $0.08-8.03 \mathrm{wt} . \%$, indicating that the GPs and granodiorites might be S-granites and I-type granites, respectively. In addition, the GPs were subjected to low-grade effects of alteration, which resulted in obvious variation ranges for the $\mathrm{A} / \mathrm{NK}$ and $\mathrm{A} / \mathrm{CNK}$ ratios. Even though the plots on the A/CNK-A/NK diagram are relatively scattered, they are concentrated mostly in the peraluminous region (Figure 12(d)), which is consistent with the behavior of S-type granites $(\mathrm{A} / \mathrm{CNK}>1.10)$. Furthermore, the samples of GPs and granodiorites fall mostly within the fields of S-type granites in the ACF I-S-type granite discriminant diagram (Figure 17(e)), with a few samples falling within the fields of I-type granites. This preliminarily suggests that the GPs and Yangla granodiorites belong to S- 


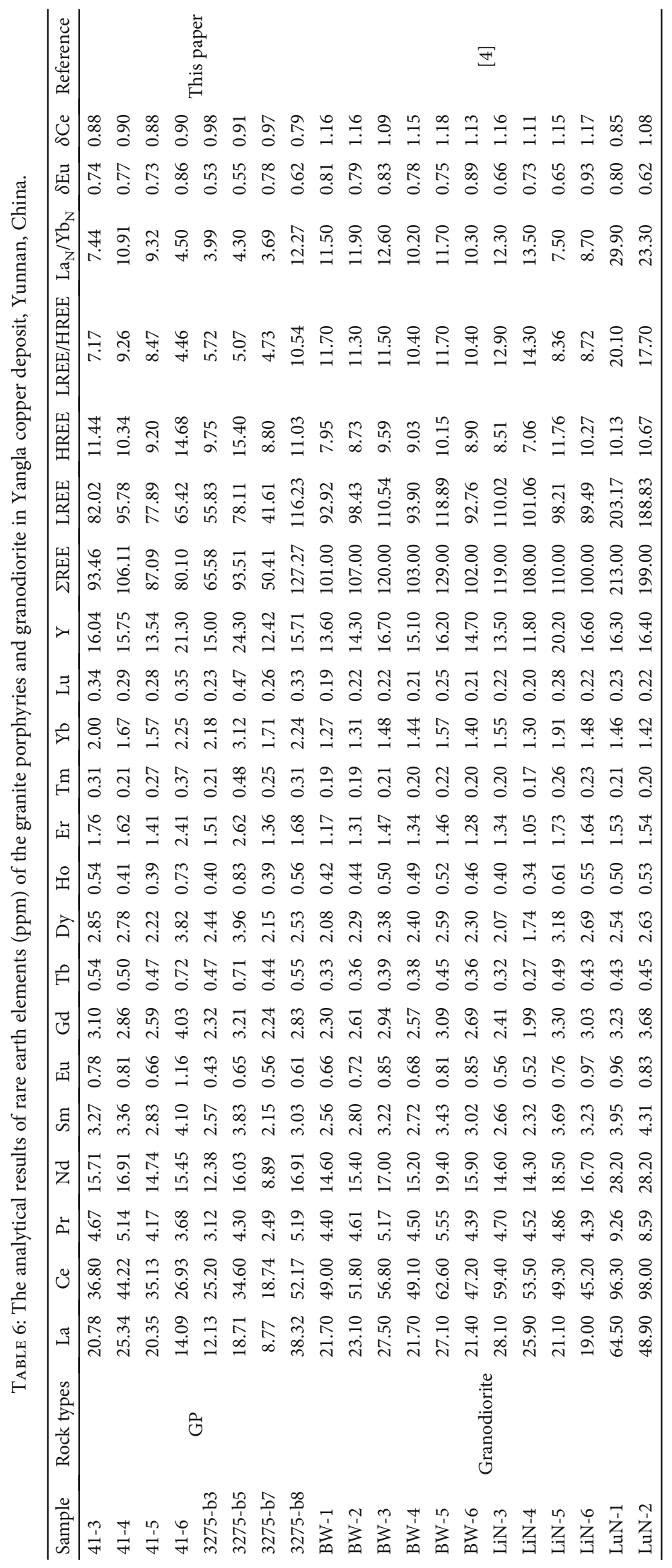




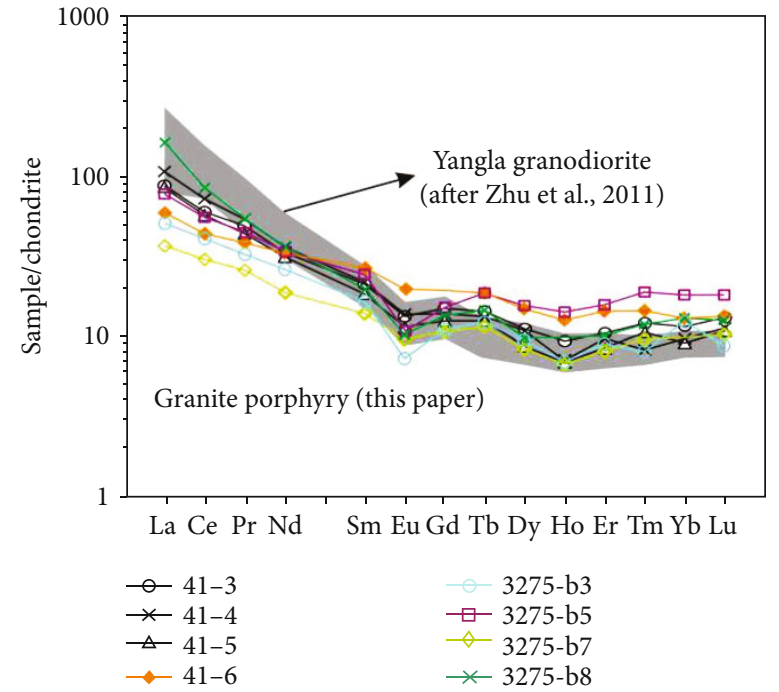

(a)

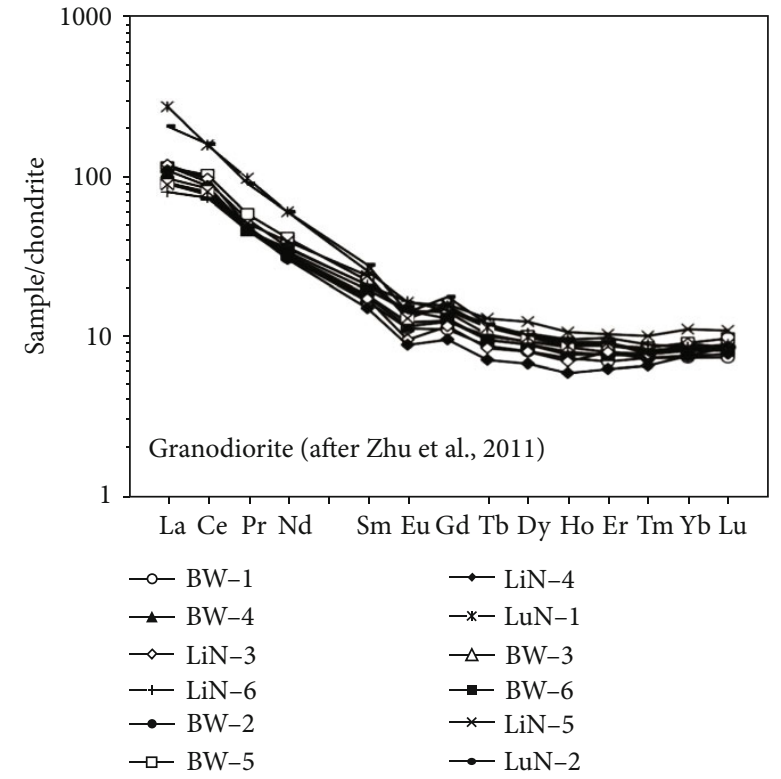

(b)

FIGURE 15: Chondrite-normalized REE patterns of the granite porphyries (a) and granodiorite (b) in Yangla copper deposit, Yunnan, China (after Sun and Mcdonough, 1989 [79]).

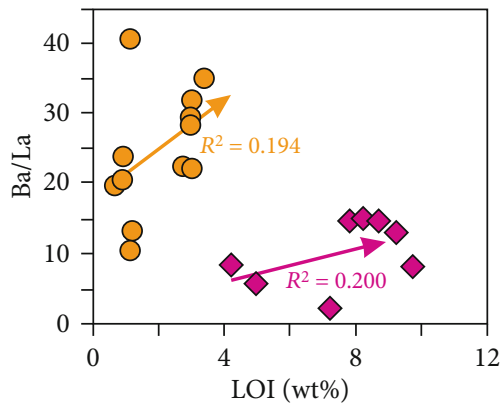

Granite porphyry (this paper)

Granodiorite (Zhu et al., 2011)

(a)

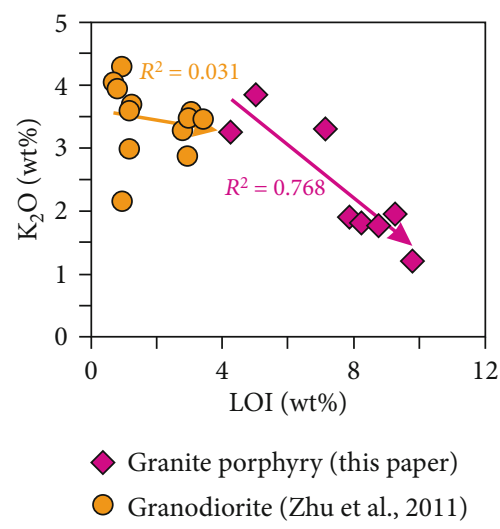

(d)

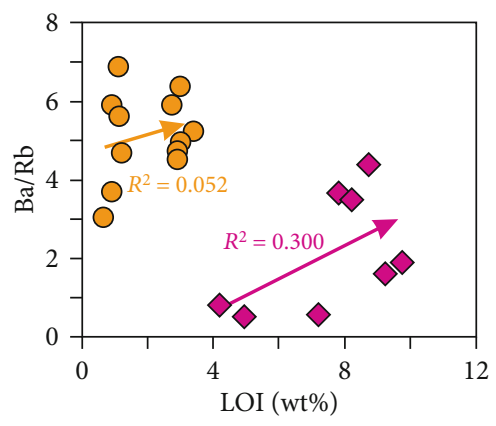

Granite porphyry (this paper)

Granodiorite (Zhu et al., 2011)

(b)

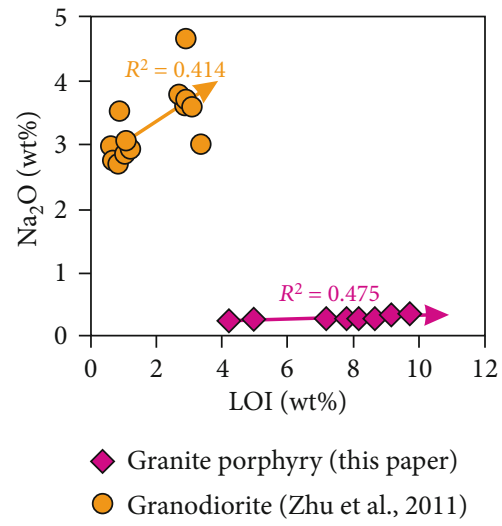

(e)

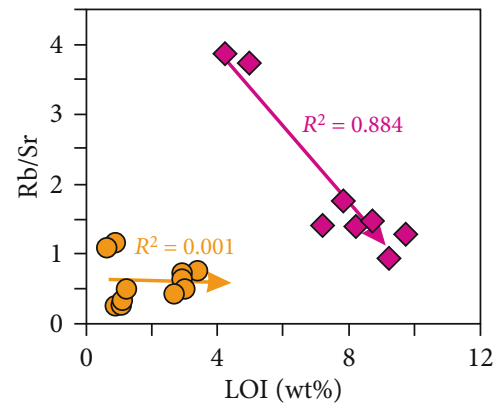

Granite porphyry (this paper)

O Granodiorite (Zhu et al., 2011)

(c)

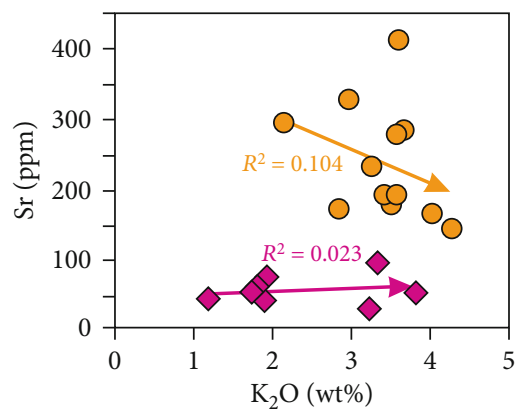

Granite porphyry (this paper)

O Granodiorite (Zhu et al., 2011)

(f)

Figure 16: The diagram $\mathrm{Ba} / \mathrm{La}, \mathrm{Ba} / \mathrm{Rb}, \mathrm{Rb} / \mathrm{Sr}, \mathrm{K}_{2} \mathrm{O}$, and $\mathrm{Na}_{2} \mathrm{O}$ vs. $\mathrm{LOI}$ and $\mathrm{Sr}$ vs. $\mathrm{K}_{2} \mathrm{O}$ of the granite porphyries and granodiorite, $\mathrm{Yangla} \mathrm{Cu}$ deposit, Yunnan, China (after Wang et al., 2019 [46]). 


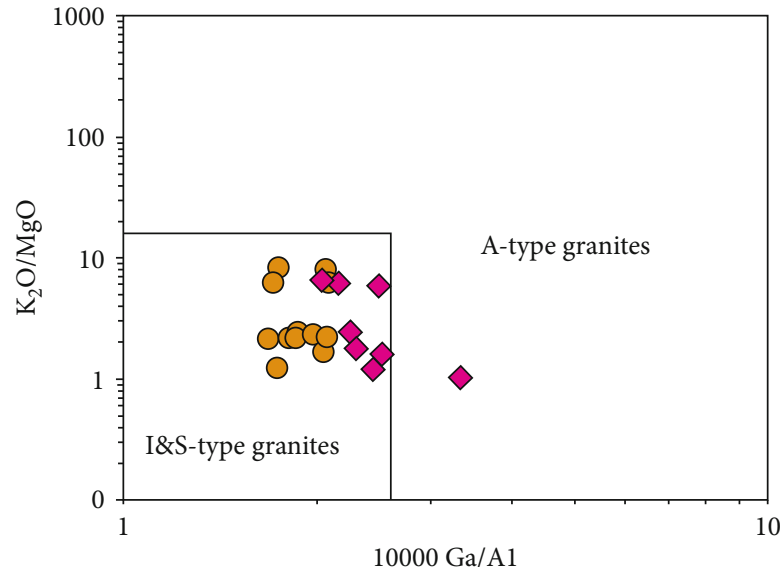

Granite porphyry (this paper)

Granodiorite (Zhu et al., 2011)

(a)

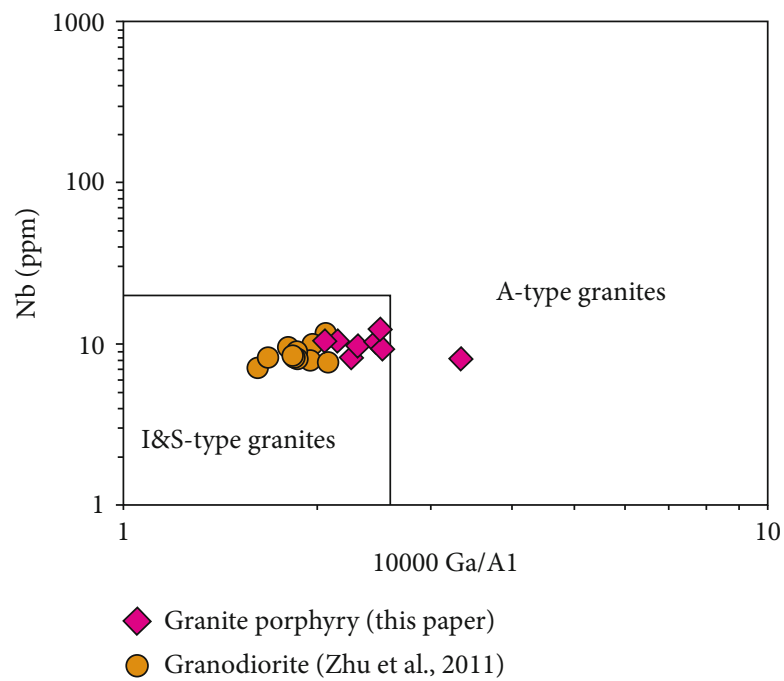

(c)

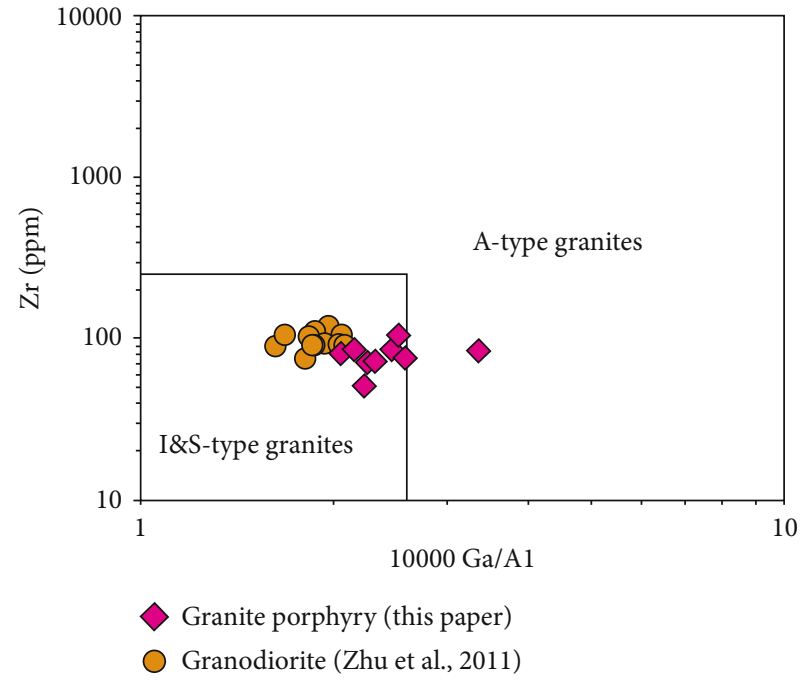

(b)

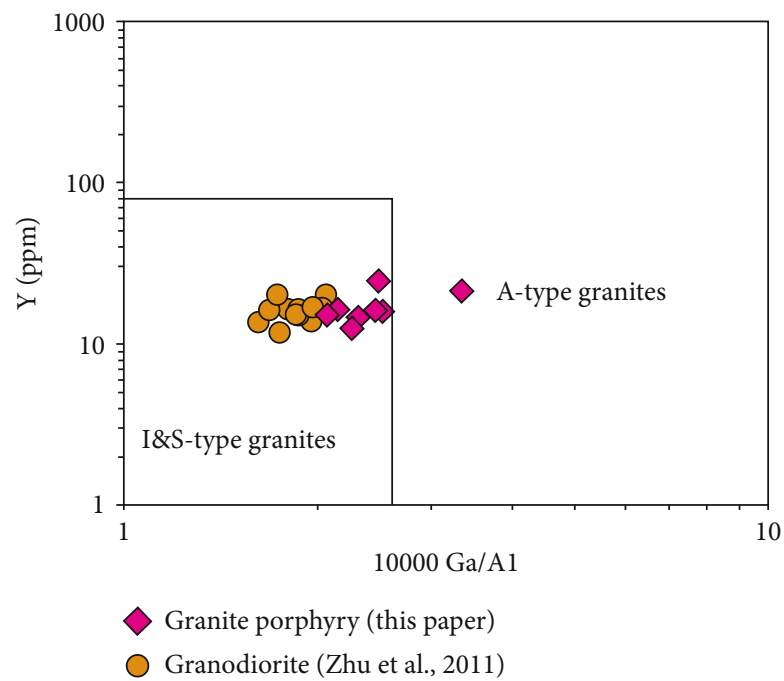

(d)

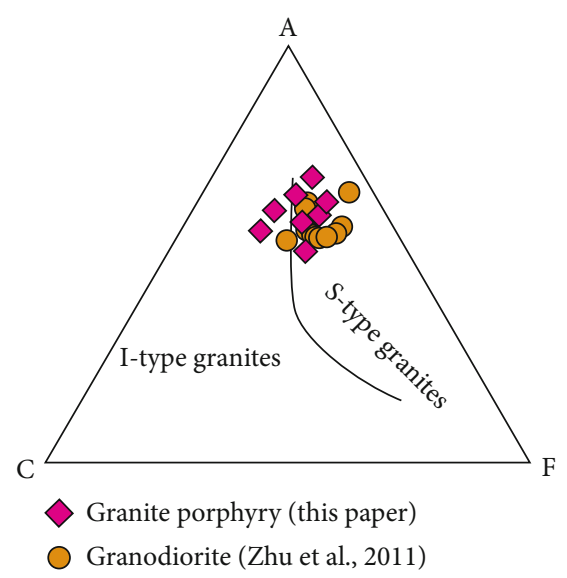

(e)

Figure 17: Plot of major elements $\left(\mathrm{K}_{2} \mathrm{O} / \mathrm{MgO}\right)$ and trace elements $(\mathrm{Zr}, \mathrm{Nb}$, and $\mathrm{Y})$ vs. $10000 \mathrm{Ga} / \mathrm{Al}$ of the granite porphyries and granodiorite in Yangla copper deposit, Yunnan, China (after Whalen, 1987 [80]) $\mathrm{A}=\mathrm{Al}_{2} \mathrm{O}_{3}+\mathrm{Fe}_{2} \mathrm{O}_{3}-\mathrm{Na}_{2} \mathrm{O}-\mathrm{K}_{2} \mathrm{O}, \mathrm{C}=\mathrm{CaO}-3.3 \mathrm{P}_{2} \mathrm{O}_{5}$, and $\mathrm{F}=\mathrm{FeO}$ $+\mathrm{MgO}+\mathrm{MnO}$. 


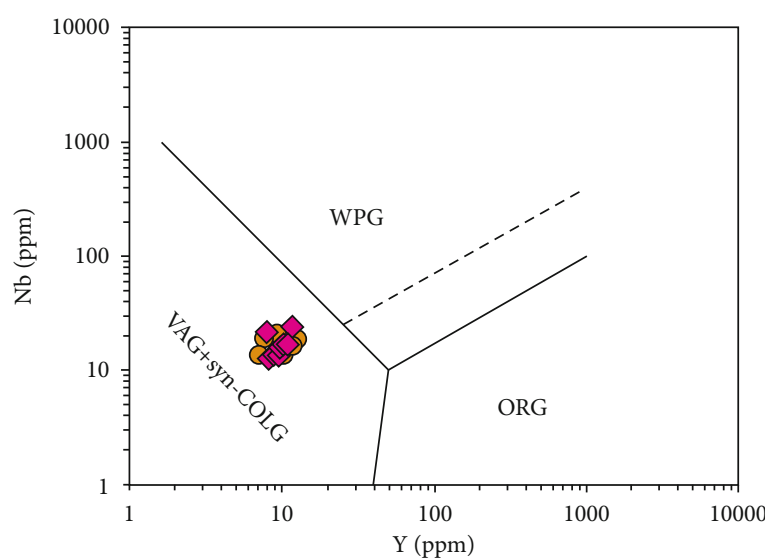

Granite porphyry (this paper)

Granodiorite (Zhu et al., 2011)

(a)

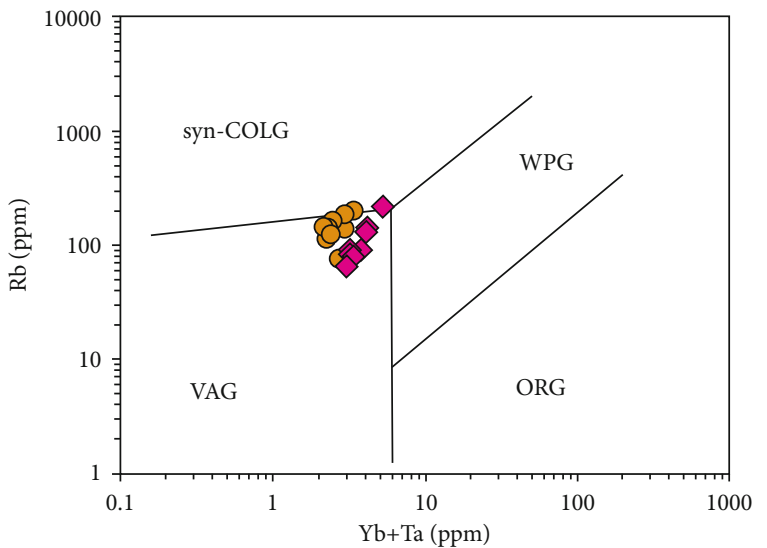

Granite porphyry (this paper)

Granodiorite (Zhu et al., 2011)

(c)

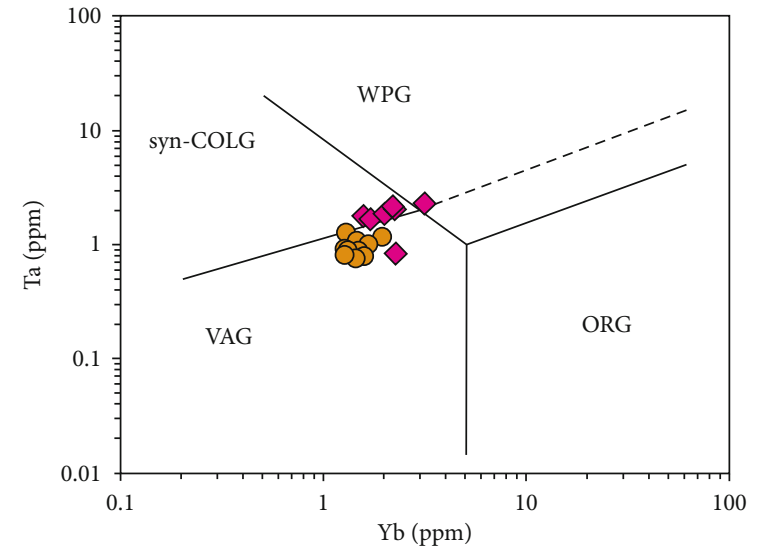

Granite porphyry (this paper)

Granodiorite (Zhu et al., 2011)

(b)

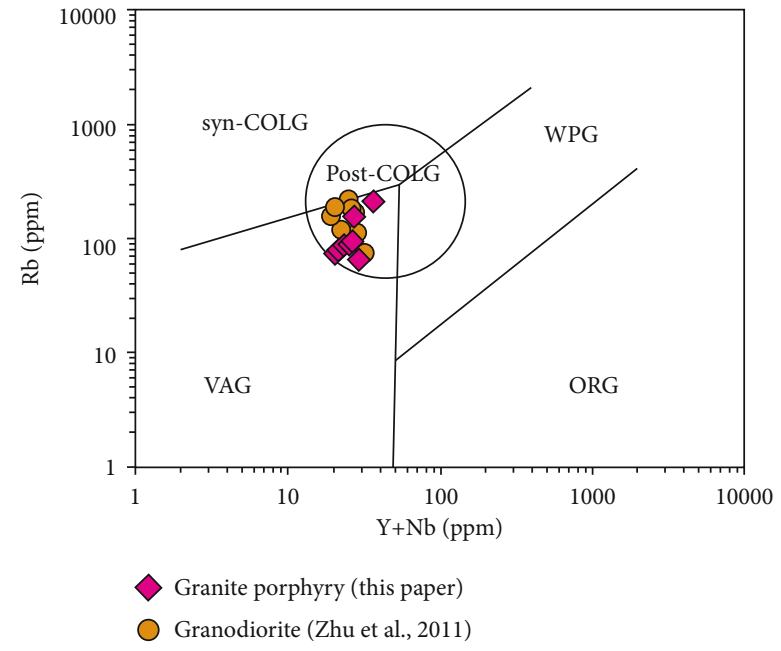

(d)

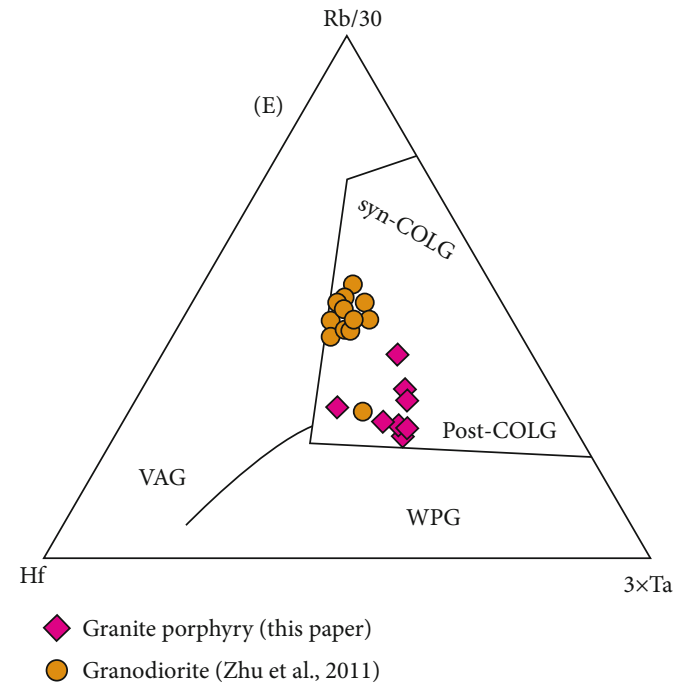

(e)

FIgURE 18: The tectonic setting discrimination diagrams for the granite porphyries and granodiorite of the Yangla copper deposit, Yunnan, China (after Maniar and Piccoli, 1989 [78]; Pearce et al., 1984 [81]). VAG: volcanic arc granite; sny-COLG: sny-collision granites; WPG: within-plate granites; ORG: oceanic ridge granites; post-COLG: postcollision granites: COLG: collision granites. 


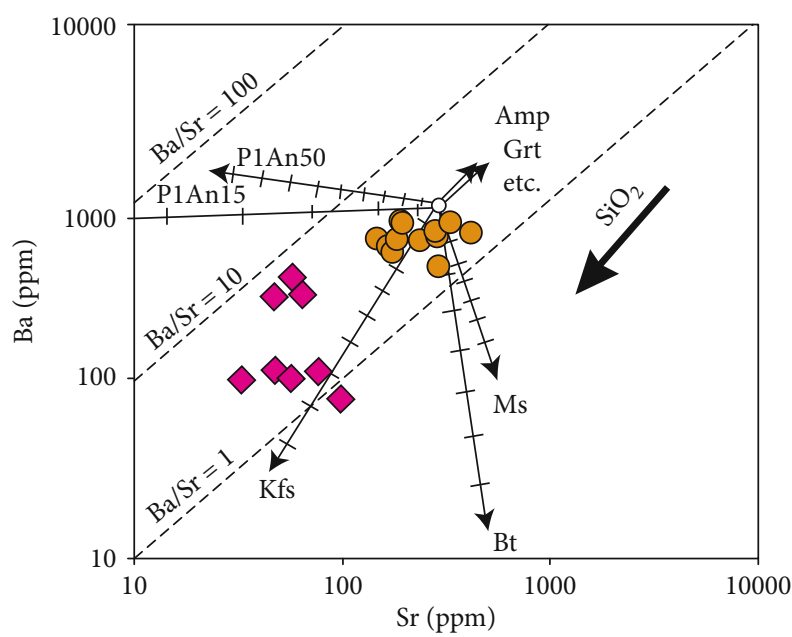

Granite porphyry (this paper)

Granodiorite (Zhu et al., 2011)

(a)

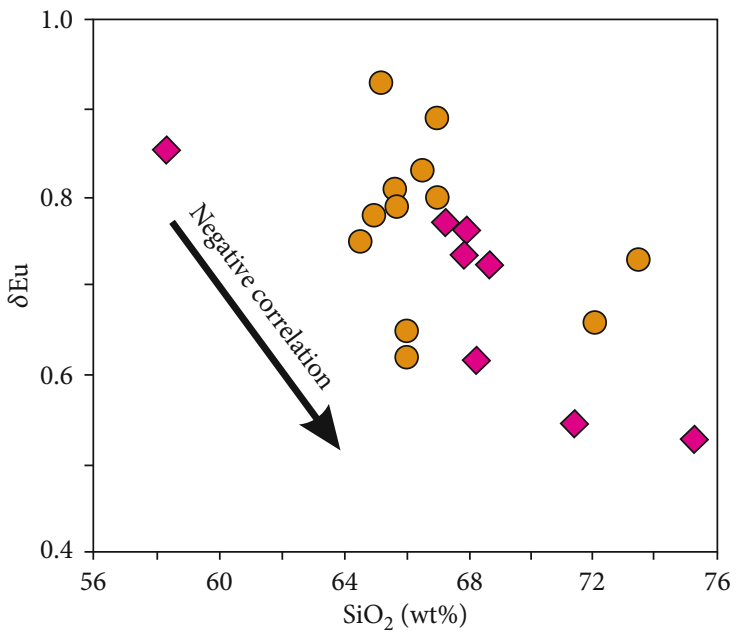

Granite porphyry (this paper)

Granodiorite (Zhu et al., 2011)

(c)

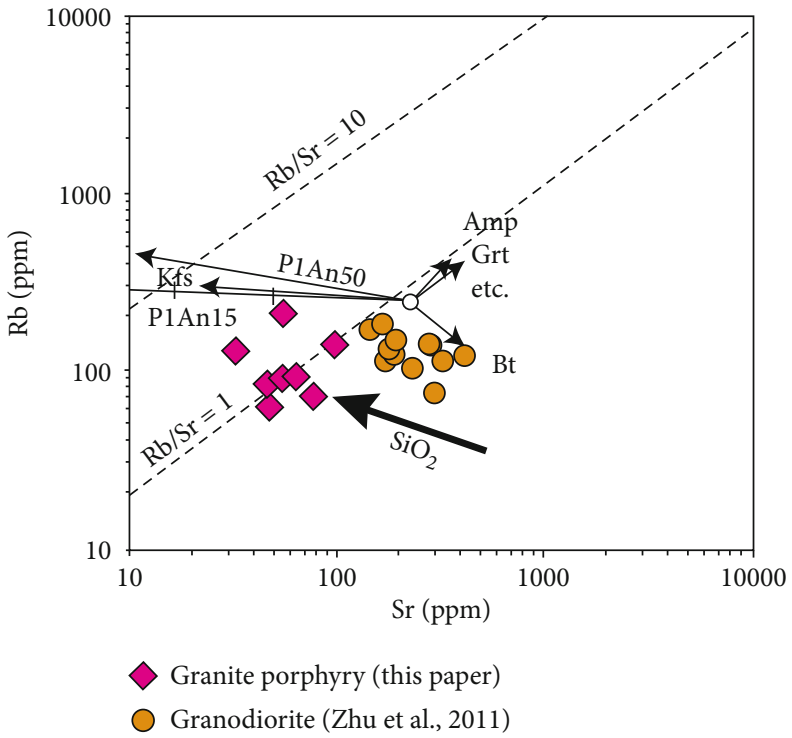

(b)

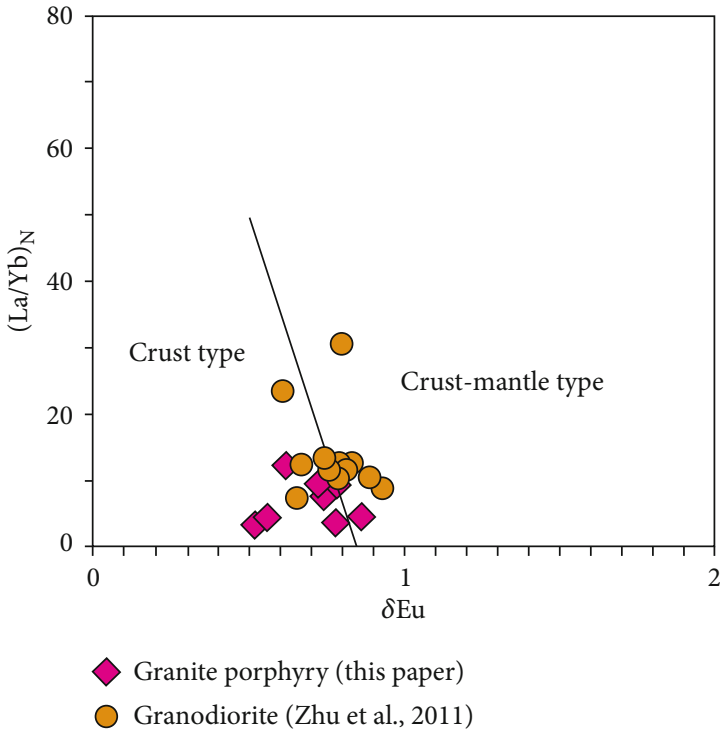

(d)

Figure 19: Plot of $\mathrm{Sr}$ vs. $\mathrm{Ba}(\mathrm{a}), \mathrm{Sr}$ vs. $\mathrm{Rb}(\mathrm{b}), \delta \mathrm{Eu}$ vs. $\mathrm{SiO}_{2}(\mathrm{c})$, and $(\mathrm{La} / \mathrm{Yb})_{\mathrm{N}} \mathrm{vs} . \delta \mathrm{Eu}(\mathrm{d})$ for the granite porphyries and granodiorite of the Yangla copper deposit, Yunnan, China (after Rollinson,1993 [76], Janoušek et al., 2004 [83], Lu et al., 2019 [71]).

type granites. A slightly positive correlation is present between the $\mathrm{SiO}_{2}$ and $\mathrm{P}_{2} \mathrm{O}_{5}$ values (Figure 11(h)), which is consistent with the evolution trend of S-type granite. However, the Yangla granodiorite plutons have a negativecorrelation evolution trend (Figure 11(h)) and might belong to I-type granites. The $\mathrm{Pb}$ and $\mathrm{Y}$ values negatively correlate with the $\mathrm{SiO}_{2}$ values, which is consistent with the evolutionary trend of S-type granites (Figures 14(e) and 14(f)). This indicates that the GPs might belong to S-type granites [60, 61]. The GP samples show clear positive correlation in the $\mathrm{Y}$ versus $\mathrm{Rb}$ (Figure 14(g)) and Th versus Rb (Figure 14(h)) diagrams, suggesting that the GPs might be I-type granites. However, the granodiorite plutons show clear positive correlations in the $\mathrm{Pb}$ versus $\mathrm{SiO}_{2}$ (Figure 14(e)) and Th versus $\mathrm{Rb}$ (Figure 14(h)) diagrams, indicating that the Yangla granodi- orites might be I-type granites. This is consistent with previous research results $[2,4,7,28]$. Furthermore, clear negative correlations were noted in the $\mathrm{Y}$ versus $\mathrm{SiO}_{2}$ (Figure 14(f)) and $\mathrm{Y}$ versus $\mathrm{Rb}$ (Figure 14(g)) diagrams, indicating that the granodiorite plutons might belong to S-type granites. Therefore, the aforementioned geochemical characteristics of the GPs and Yangla granodiorite plutons might have the comprehensive characteristics of S- and Itype granites, respectively.

A-type granite represents anhydrous granite produced in an extensional tectonic setting, and its source area has diverse materials. The mineral compositions of A-type granites are quartz, mafic minerals (Fe-rich), alkaline feldspar, and plagioclase, which are characterized by enrichment in $\mathrm{Si}, \mathrm{Na}$, $\mathrm{Zr}, \mathrm{Nb}, \mathrm{Ce}, \mathrm{Y}, \mathrm{Ta}$, and $\mathrm{K}$ and deficiency in $\mathrm{Ca}, \mathrm{Mg}$, high 


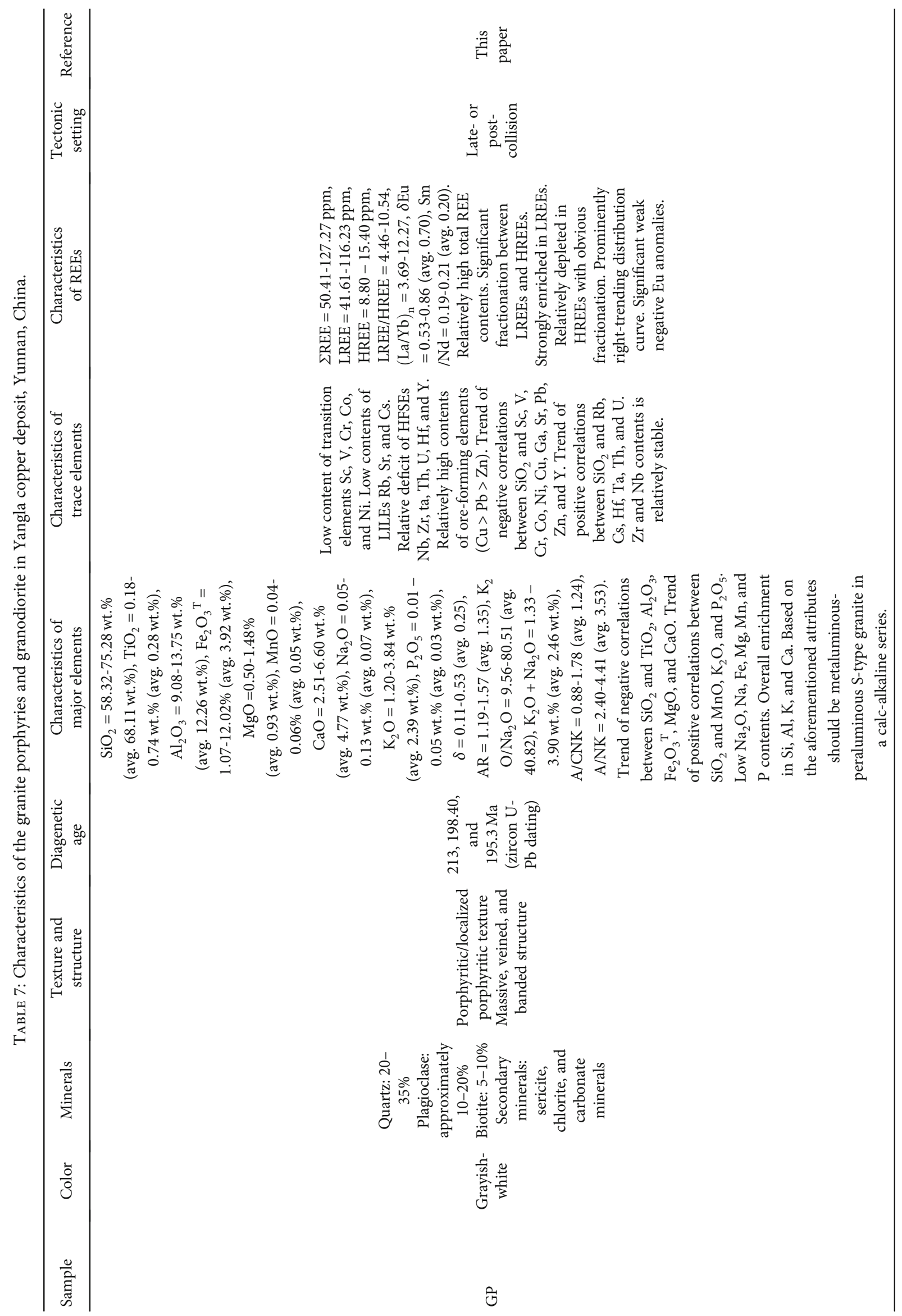




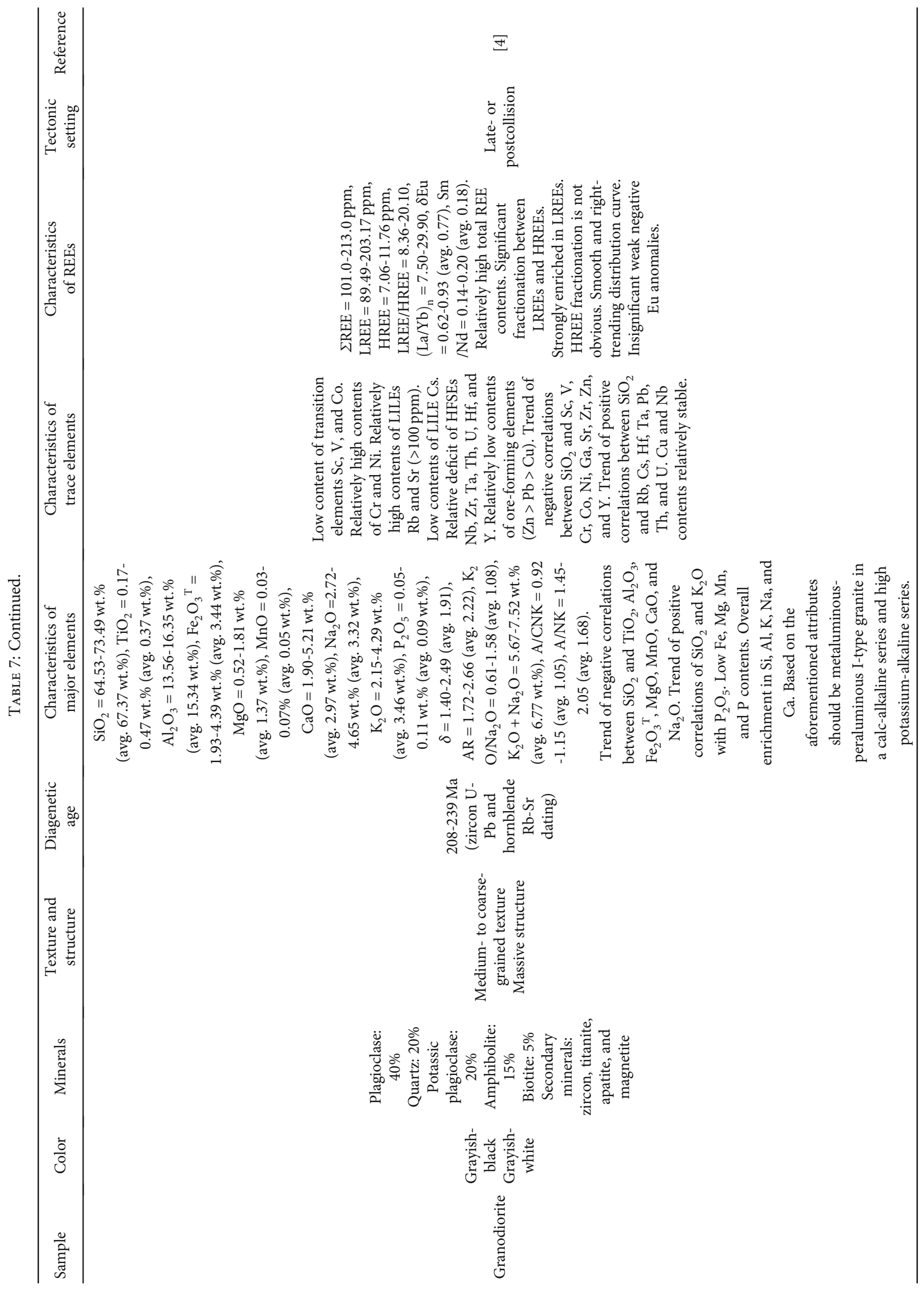




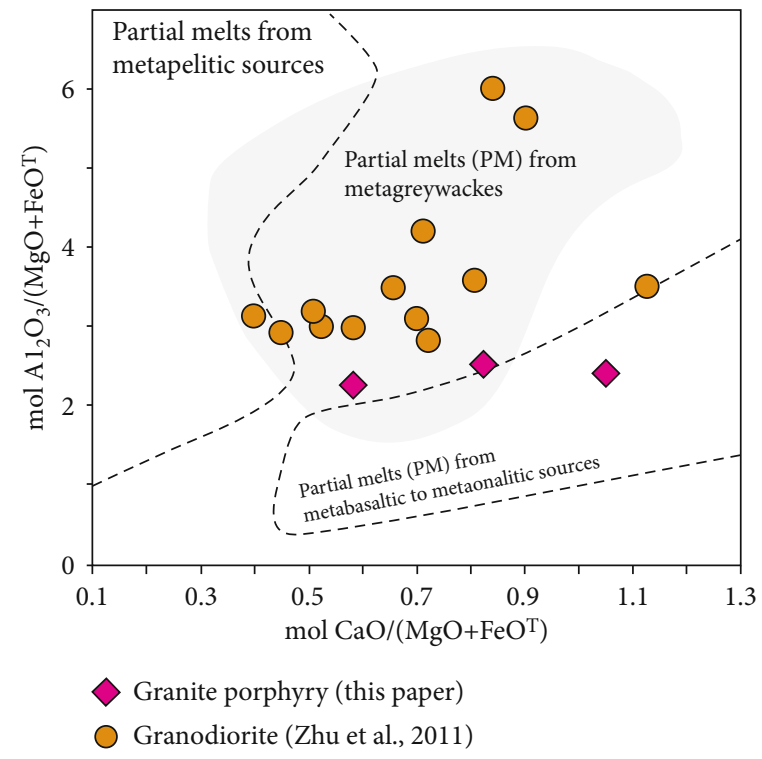

(a)

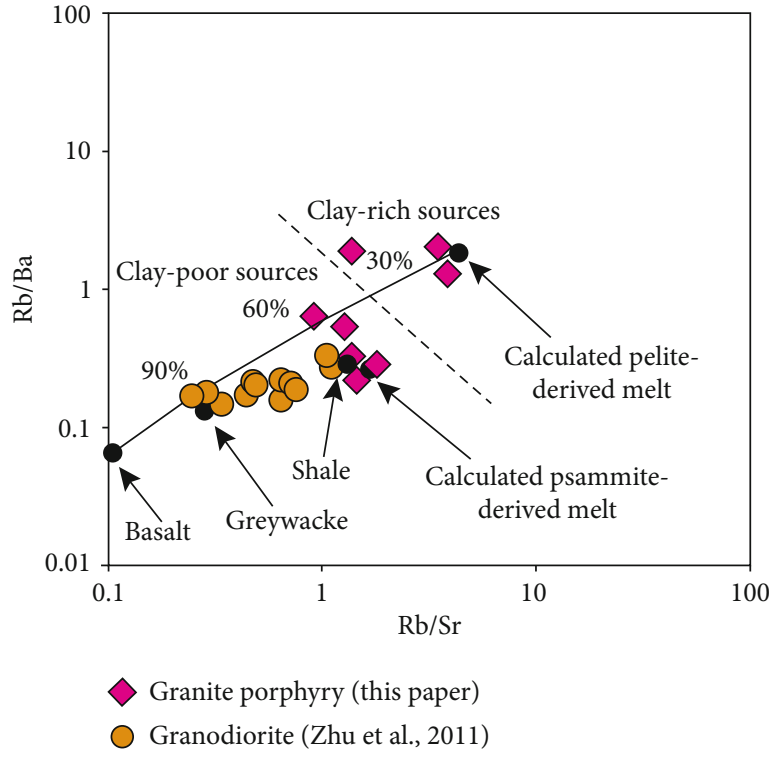

(b)

Figure 20: Selected discrimination diagrams for the granite porphyries and granodiorite of the Yangla copper deposit, Yunnan, China ((a) $\mathrm{Al}_{2} \mathrm{O}_{3} /\left(\mathrm{MgO}+\mathrm{FeO}^{\mathrm{T}}\right)$ vs. $\mathrm{CaO} /\left(\mathrm{MgO}+\mathrm{FeO}^{\mathrm{T}}\right)$ (after Altherr et al., 2000 [69]). (b) Rb/Ba vs. Rb/Sr (after Sylvester,1998 [70]).

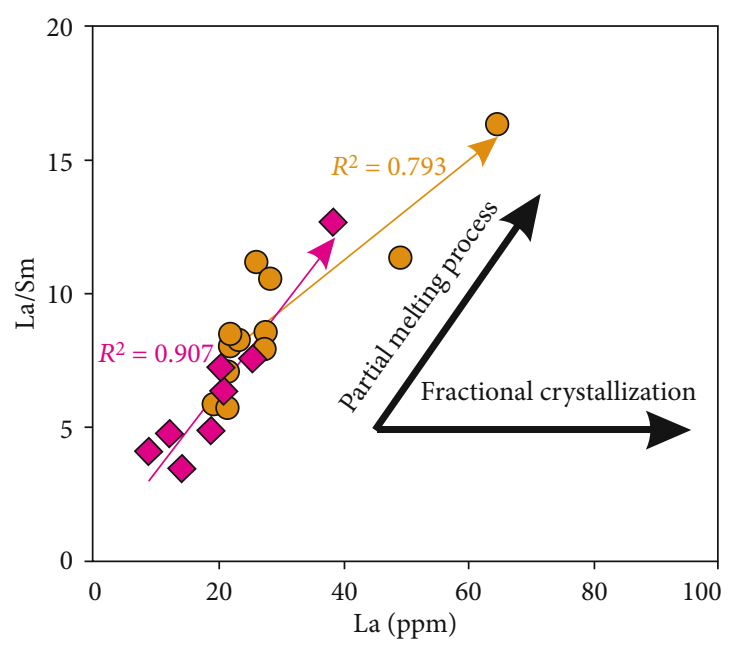

Granite porphyry (this paper)

Granodiorite (Zhu et al., 2011)

(a)

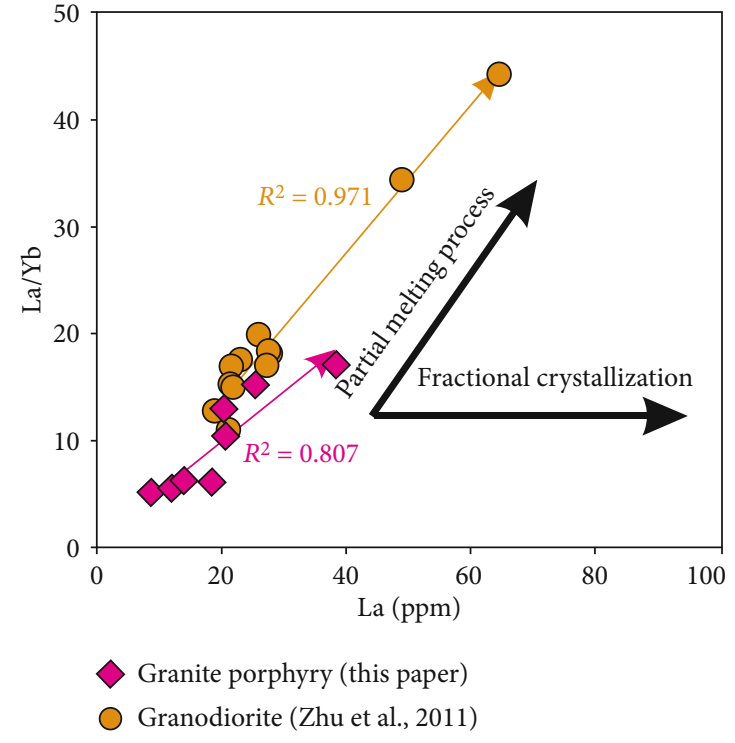

(b)

Figure 21: Plot of La vs. La/Sm and La vs. La/Yb for the granite porphyries and granodiorite of the Yangla copper deposit, Yunnan, China.

$\mathrm{FeO}^{\mathrm{T}} / \mathrm{MgO}$ values, and strong deficiency in $\mathrm{Ba}, \mathrm{Sr}, \mathrm{P}$, and $\mathrm{Ti}$, which have obvious negative Eu anomalies [62]. The trace elements $\mathrm{Zr}+\mathrm{Nb}+\mathrm{Ce}+\mathrm{Y}=(130.52-173.38) \mathrm{ppm}$ and $\mathrm{Zr}=$ (70.26-102.64) ppm of the GPs are lower than the lower limit of A-type granites $(\mathrm{Zr}+\mathrm{Nb}+\mathrm{Ce}+\mathrm{Y}>350 \mathrm{ppm}$ and $\mathrm{Zr}>$ $250 \mathrm{ppm})[4,25,58,63]$. The GP and granodiorite samples consistently fall within the fields of I- and S-type granites in the $\mathrm{K}_{2} \mathrm{O} / \mathrm{MgO}-10000 \mathrm{Ga} / \mathrm{Al}$ (Figure $17(\mathrm{a})$ ), $\mathrm{Zr}-10000 \mathrm{Ga} / \mathrm{Al}$ (Figure 17(b)), Nb-10000 Ga/Al (Figure 17(c)), and Y$10000 \mathrm{Ga} / \mathrm{Al}$ (Figure $17(\mathrm{~d})$ ) diagrams. A relative deficit of HFSEs such as Nb, Ta, and $\mathrm{Zr}$, was noted, which is also incon- sistent with the characteristics of A-type granites that are rich in $\mathrm{Nb}, \mathrm{Ta}$, and $\mathrm{Zr}$. This indicates that the GPs and granodiorite plutons are not A-type granites, although they might be I- or S-type granites $[4,7,25,63]$.

M-type granites formed during the later stage of the fractional crystallization process of basaltic magma in a tectonic setting of an ocean island arc and a mid-ocean ridge; they belong to mantle-derived granite, with an $\mathrm{A} /$ $\mathrm{CNK} \leq 0.6$, and deficiencies in $\mathrm{Ba}, \mathrm{Ti}$, and $\mathrm{P}$ [64]. The geochemical features of the granite plutons from the entire Yangla mining district do not coincide with M-type 


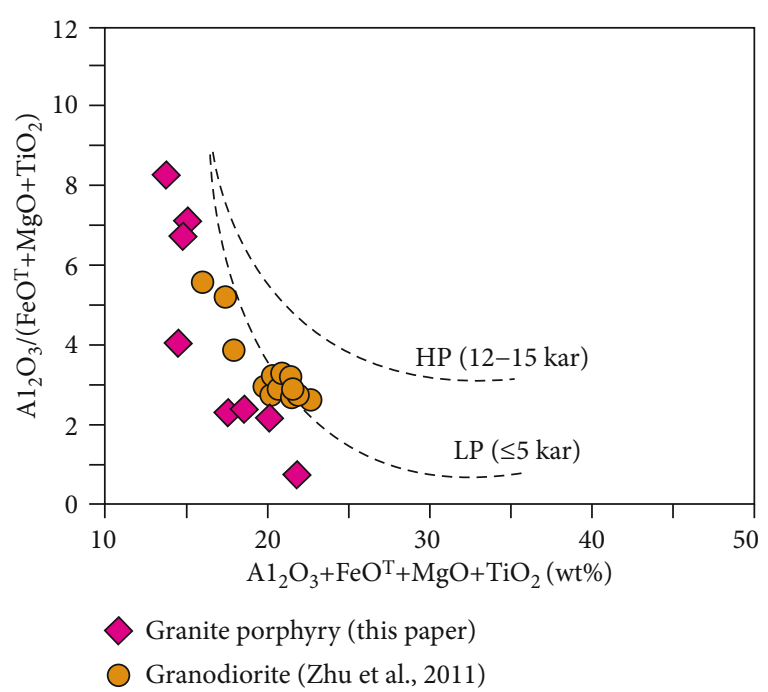

FIgURE 22: Composition diagrams of the granite porphyry and granodiorite. The area between the high-pressure (12-15 kbar) and low-pressure ( $\leq 5 \mathrm{kbar})$ curves encompasses the range of depths at which mantle-crust interaction takes place (After Douce, 1999 [82]).

granite and thus do not belong to the M-type granites in this study $[4,7,25,65-67]$.

5.4. Implications of Tectonic Setting. The JSB is an important component of the Paleo-Tethys Ocean; therefore, its evolution is significant for the entire eastern Paleo-Tethys Ocean [2]. It has been suggested that the Jinshajiang Ocean opened in the Late Devonian or Early Carboniferous ( $360 \mathrm{Ma})$ and that the regional collision event ended prior to the Late Triassic $(\sim 200 \mathrm{Ma})[2,3]$. For the subduction-collision-related events, the Niangjiushan plagiogranites and the Jiyidu granodiorites in the JSB yielded SHRIMP zircon ages of $285 \pm 6 \mathrm{Ma}$ and $263 \pm 6 \mathrm{Ma}$ [19], implying that the Jinshajiang oceanic slab subducted westward in a postcollisional and latecollisional tectonic setting during the Permian (290$250 \mathrm{Ma})$ and the Late Triassic $(250-200 \mathrm{Ma})$, respectively. The three GPs have zircon $\mathrm{U}-\mathrm{Pb}$ ages of $213 \pm 15 \mathrm{Ma}$, $198.40 \pm 8.6 \mathrm{Ma}$, and $195.3 \pm 6.4 \mathrm{Ma}$, respectively. Therefore, it is conceivable that these GPs are related to a postcollisional or late-collisional tectonic setting.

Furthermore, within the regional area, the Ludian intrusion (234-214 Ma) and Lincang intrusion ( 230 Ma) have similar geochemical characteristics and formation ages as those of the GPs and might have been produced under a postcollisional or late-collisional setting [68]. Additionally, in the tectonic setting discrimination diagram plots (Figure 18), the GPs and Yangla granodiorite samples show the following characteristics: (i) All of the GPs and Yangla granodiorite samples fall within the fields of syncollisional granite (syn-COLG) and volcanic arc granite (VAG) in the $\mathrm{Y}-\mathrm{Nb}$ (Figure 18(a)), Yb-Ta (Figure 18(b)), and ( $\mathrm{Yb}+\mathrm{Ta})-$ $\mathrm{Rb}$ (Figure 18(c)) diagrams. (ii) The majority of the GPs and Yangla granodiorite samples fall within the field of postcollision granite (post-COLG), although a few plotted within the VAG areas in the $(\mathrm{Y}+\mathrm{Nb})-\mathrm{Rb}$ (Figure 18(d)) diagrams. (iii) All of the GPs samples and the majority of the Yangla granodiorite samples fall within the post-COLG field, although a few of the Yangla granodiorite samples fall within the syn-COLG areas in the $\mathrm{Rb} / 30-\mathrm{Hf}-3 \times \mathrm{Ta}$ (Figure 18(e)) diagrams. Considering the achievements of previous studies, the tectonic setting of the Yangla granodiorites should have been late- or postcollision $[2,4,7,25,34,37]$. This is consistent with the geotectonic setting of the JSB, which had fully entered the collision-orogenic stage, leading to the formation of COLG $[4,7,25,33]$. Therefore, the GPs might have been generated under a post- or late-collisional tectonic setting, which is consistent with the Yangla granodiorite plutons.

5.5. Magma Source. The geochemical characteristics of some elements can be used to trace the materials of magmatic source regions $[69,70]$. In the $\mathrm{Al}_{2} \mathrm{O}_{3} /\left(\mathrm{MgO}+\mathrm{FeO}^{\mathrm{T}}\right)$ versus $\mathrm{CaO} /\left(\mathrm{MgO}+\mathrm{FeO}^{\mathrm{T}}\right)$ and $\mathrm{Rb} / \mathrm{Ba}$ versus $\mathrm{Rb} / \mathrm{Sr}$ discriminant diagrams (Figure 20), the GPs and granodiorite plutons both exhibit similar source material compositions-mainly claypoor rocks (sandstone and shale) with small amounts of basic-acidic rocks. This indicates that they might share the same (or similar) sources; the predominant source of the original magma was a crust-mantle mixture [2-4]. In the $(\mathrm{La} / \mathrm{Yb})_{\mathrm{N}}-\delta(\mathrm{Eu})$ diagram (Figure 19(d)), the GPs and granodiorite plutons samples also fall mainly within the crust-type and crust-mantle-type fields, respectively. This preliminary study indicates that the initial magma formed through interaction of the mantle and crust and then underwent partial melting in the lower crust before being emplaced as intrusive complexes [71]. Therefore, the samples belong to multistage homologous intrusive complexes. Thus, the GPs and granodiorites might have shared a similar original magma source and genesis and are likely products of the same magmatic system. These inferences are also supported by various factors: (a) The duration of the magmatic activities in the Yangla mining district is likely $\sim 30 \mathrm{Ma}[28,37]$; (b) the GPs and granodiorites, at $195-213 \mathrm{Ma}$ and $208-239 \mathrm{Ma}$, respectively, have an overlapping region of replacement ages, indicating continuity of magmatic system evolution in the Yangla mining district; and (c) the GPs and granodiorites have nearly identical geochemical characteristics, including those of major and trace elements and REEs, as well as tectonic settings.

5.6. Petrogenetic Process and Model of the GPs. In the La/Sm versus $\mathrm{La}$ (Figure 21(a)) and $\mathrm{La} / \mathrm{Yb}$ versus $\mathrm{La}$ (Figure 21(b)) discriminant diagrams of the magmatic process, the GPs and granodiorite plutons show an inclined distribution, suggesting that the diagenetic process involved mainly partial melting rather than fractional crystallization. The GPs and the majority of the granodiorite samples fall within the field of low pressure $(<5 \mathrm{kbar})$ in the $\left(\mathrm{Al}_{2} \mathrm{O}_{3} / \mathrm{FeO}^{\mathrm{T}}+\mathrm{MgO}+\mathrm{TiO}_{2}\right)$ versus $\left(\mathrm{Al}_{2} \mathrm{O}_{3}+\mathrm{FeO}^{\mathrm{T}}+\mathrm{MgO}+\mathrm{TiO}_{2}\right)$ (Figure 22) pressure discrimination diagram. This suggests that the diagenetic depth of the GPs is slightly less than that of the Yangla granodiorites and is consistent with the characteristics of the stage of magma system evolution in the Yangla mining district. In addition, the $\mathrm{Sr}-\mathrm{Ba}$ (Figure 19(a)), Sr-Rb (Figure 19(b)), and $\mathrm{SiO}_{2}-\delta \mathrm{Eu}$ (Figure 19(c)) diagrams indicate crystallization of various 


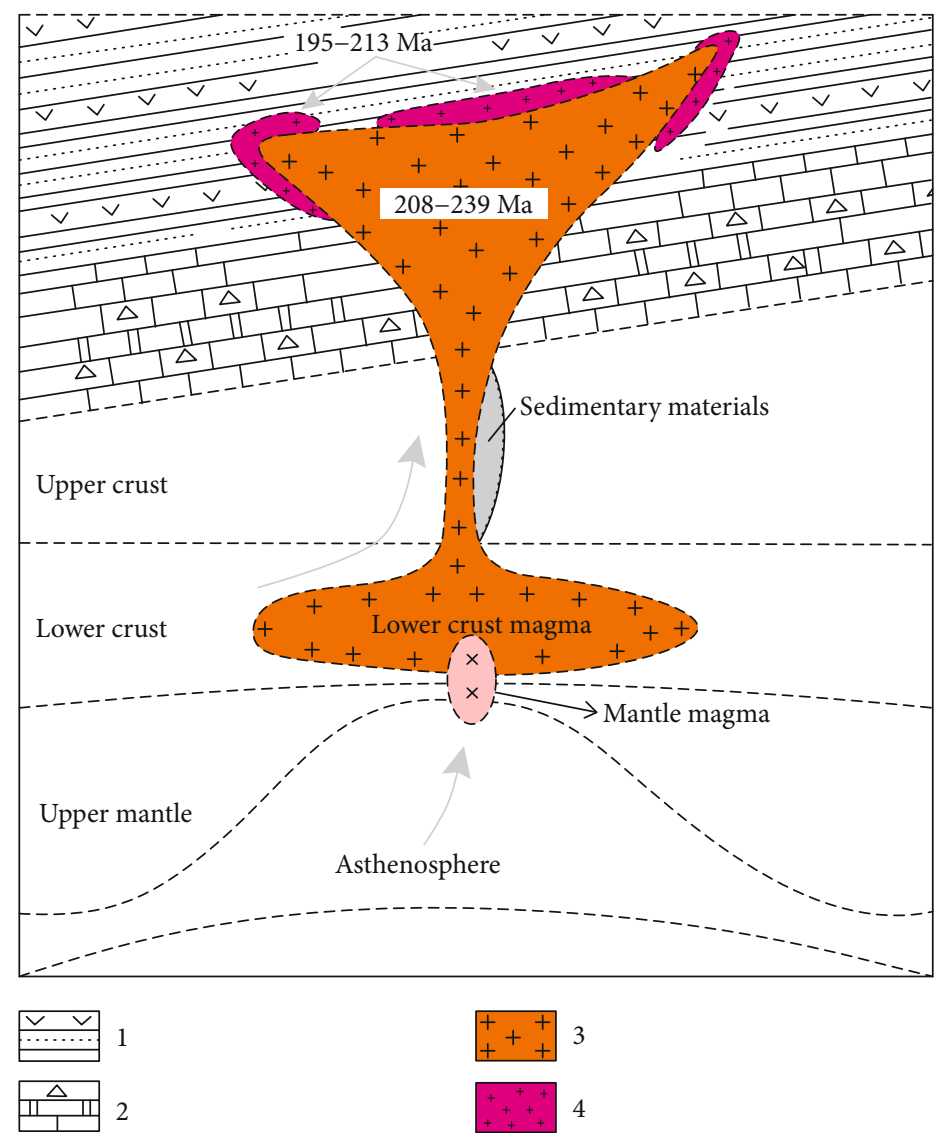

FIGURE 23: The diagenetic model of the granite porphyry and granodiorite plutons in the Yangla copper deposit, Yunnan, China. 1-sandslate formation, 2-carbonate formation, 3-granodiorite plutons, and 4-granite porphyry.

minerals such as plagioclase and biotite during the diagenetic processes of the GPs and Yangla granodiorite plutons.

As mentioned previously, the JSB experienced the opening of the Jinshajiang Ocean in the Late Devonian or Early Carboniferous ( $360 \mathrm{Ma})$, a Jinshajiang oceanic slab westward subduction event in the Permian (290-250 Ma), and a post- or late-collisional event in the Late Triassic (250$200 \mathrm{Ma}$ ). The underplating of mantle-derived magma at the crust-mantle boundary is an important process by which crust-mantle mixing can be triggered $[2,72]$. Therefore, the diagenetic process of the GPs and Yangla granodiorite plutons can be described as follows. Regional tension in the late- and postcollision tectonic setting could have caused the asthenosphere to surge upward to underplate the base of the lower crust [2-4]. Under the conditions of high temperature and decompression, the lower crust remelted xand mixed with the mantle-derived magma. The resultant mixture was thus contaminated with large amounts of upper crustal fusible components including sedimentary materials during its ascent, forming a ternary magma (upper crust + lower crust + mantle). The subsequent partial melting led to the formation of the Yangla granodiorite plutons with I-type granites coupled with minor affinity to S-type granites in the shallow emplacement process (low pressure $\leq 5 \mathrm{kbar}$ ). The residual magma, which had more contamination by upper crust sedimentary materials, then entered an epithermal setting of low pressure ( $<5 \mathrm{kbar})$ and formed GPs with S-type granites with minor affinity to Itype granites. Therefore, the GPs of the YCD were formed from residual magma following the diagenetic process of the Yangla granodiorites plutons in an epithermal setting (Figure 23).

\section{Conclusion}

We combined zircon $\mathrm{U}-\mathrm{Pb}$ age dating, whole-rock geochemical data, and REE data to constrain the geochronology, tectonic setting, and petrogenesis of the GPs analyzed in this study. The following conclusions were reached.

(1) The zircon $\mathrm{U}-\mathrm{Pb}$ dating results revealed GP formation at $195-213 \mathrm{Ma}$, which is slightly later than that of the Yangla granodiorite plutons, at 208-239 Ma, under a late- or postcollisional tectonic setting. The results suggest that the collision was completed during the Early Jurassic and that the magmatic activities occurring in the Yangla mining district might have lasted for $\sim 44 \mathrm{Ma}$, during 239-195 Ma

(2) Compared with the Yangla granodiorite plutons, the GPs share similar major, trace, and REE geochemistry, although they are rich in $\mathrm{Cu}, \mathrm{Pb}, \mathrm{Cs}, \mathrm{Ta}$, and $\mathrm{U}$ 
and deficient in Rb, P, Ta, Ti, $\Sigma$ REE, and LREE, with insignificantly negative anomalies of Eu and slightly weak negative anomalies of $\mathrm{Ce}$. This indicates that these granites underwent partial melting with separation of the Ti-bearing phase, plagioclase, and biotite. This preliminary result indicates that the GPs and the Yangla granodiorite plutons might have had the same or similar magmatic source area. Genetically, the GPs are slightly metaluminous to peraluminous S-type granites, whereas the Yangla granodiorite plutons are metaluminous to slightly peraluminous I-type granites

(3) Based on the post- or late-collisional tectonic setting, the GPs and Yangla granodiorite plutons likely originated from a ternary mixture of upper crust + lower crust + mantle materials. Such three-component magmas and subsequent partial melting could have been responsible for the generation of the Yangla granodiorite plutons and GPs in a shallow setting under low pressure $\leq 5 \mathrm{kbar}$ and an epithermal setting under low pressure of $<5 \mathrm{kbar}$, respectively

\section{Data Availability}

The data used to support the findings of this study are available from the corresponding author upon request.

\section{Conflicts of Interest}

The authors declare that they have no conflicts of interest.

\section{Acknowledgments}

This study was supported jointly by the National Natural Science Foundation of China (41862007, 41402072, and 41902085), the Yunnan Ten Thousand Talents Plan Young and Elite Talents Project (YNWR-QNBJ-2018-093), and the Analysis and Testing Foundation of Kunming University of Science and Technology (2017T20160006).

\section{References}

[1] W. C. Li, G. T. Pan, and Z. Q. Hou, Metallogenic Theory and Exploration Technique of "Sanjiang" Multi-Island Arc Basincollisional Orogeny in Southwest China, Geological Publishing House, Beijing, China, 2010.

[2] J. J. Zhu, R. Z. Hu, X. W. Bi, H. Zhong, and H. Chen, "Zircon $\mathrm{U}-\mathrm{Pb}$ ages, $\mathrm{Hf}-\mathrm{O}$ isotopes and whole-rock $\mathrm{Sr}-\mathrm{Nd}-\mathrm{Pb}$ isotopic geochemistry of granitoids in the Jinshajiang suture zone, SW China: constraints on petrogenesis and tectonic evolution of the Paleo-Tethys Ocean," Lithos, vol. 126, no. 3-4, pp. 248264, 2011.

[3] J. J. Zhu, R. Hu, J. P. Richards, X. Bi, and H. Zhong, "Genesis and magmatic-hydrothermal evolution of the Yangla skarn $\mathrm{Cu}$ deposit, Southwest China," Economic Geology, vol. 110, no. 3, pp. 631-652, 2015.

[4] J. J. Zhu, R. Z. Hu, X. W. Bi et al., "Genesis and tectonic significance of granites in the Yangla ore district, northwestern Yunnan Province," Acta Petrologica Sinica, 2011, vol. 27, no. 9, pp. 2553-2566, 2011.
[5] L. J. Du, B. Li, Z. L. Huang, J. X. Zhou, G. F. Zou, and Z. F. Yan, "Carbon-oxygen isotopic geochemistry of the Yangla Cu skarn deposit, SW China: implications for the source and evolution of hydrothermal fluids," Ore Geology Reviews, vol. 88, pp. 809-821, 2017.

[6] L. J. Du, B. Li, Z. L. Huang et al., "Mineralogy, fluid inclusion, and hydrogen and oxygen isotope studies of the intrusionrelated Yangla $\mathrm{Cu}$ deposit in the Sanjiang Region, SW China: implications for metallogenesis and deposit type," Resource Geology, vol. 70, pp. 28-49, 2019.

[7] J. Zhu, Geological, Geochemical Characteristics and Genesis of the Yangla Copper Deposit, Yunnan, Kunming University of Science and Technology, Kunming, China, Deqin Country, 2011, (in Chinese).

[8] Y. B. Wang, J. Han, P. S. Zeng et al., "U-Pb dating and Hf isotopic characteristics of zircons from granodiorite in Yangla copper deposit, Deqin County, Yunnan, Southwest China," Acta Petrologica Sinica, vol. 26, no. 6, pp. 1833-1844, 2010.

[9] X. X. Mo, F. X. Lu, S. Y. Shen et al., Sanjiang Tethyan Volcanism and Related Mineralization, Geological Publishing House, Beijing, China, 1993.

[10] Z. Q. Hou, H. Ma, K. Zaw et al., "The Himalayan Yulong porphyry copper belt: product of large-scale strike-slip faulting in eastern Tibet," Economic Geology, vol. 98, pp. 125145, 2003.

[11] Z. Q. Hou, K. Zaw, G. Pan et al., "Sanjiang Tethyan metallogenesis in S.W. China: tectonic setting, metallogenic epochs and deposit types," Ore Geology Reviews, vol. 31, no. 1-4, pp. 48-87, 2007.

[12] W. C. Li, P. S. Zeng, Z. Q. Hou, and N. C. White, "The Pulang porphyry copper deposit and associated felsic intrusions in Yunnan province, Southwest China," Economic Geology, vol. 106, pp. 79-92, 2011.

[13] J. Deng, Q. Wang, G. Li, C. Li, and C. Wang, “Tethys tectonic evolution and its bearing on the distribution of important mineral deposits in the Sanjiang region, SW China," Gondwana Research, vol. 26, no. 2, pp. 419-437, 2014.

[14] X. A. Yang, J. J. Liu, S. Y. Han et al., "Characteristics of orecontrolling structures in the Yangla copper deposit and Luchun $\mathrm{Cu}-\mathrm{Pb}-\mathrm{Zn}$ deposit, western Yunnan," Geotectonica et Metallogenia, vol. 36, pp. 248-258, 2012.

[15] J. W. Zi, P. A. Cawood, W. M. Fan et al., "Late PermianTriassic magmatic evolution in the Jinshajiang orogenic belt, SW China and implications for orogenic processes following closure of the Paleo-Tethys," American Journal of Science, vol. 313, no. 2, pp. 81-112, 2013.

[16] X. Wang, I. Metcalfe, P. Jian, L. He, and C. Wang, "The Jinshajiang-Ailaoshan suture zone, China: tectonostratigraphy, age and evolution," Journal of Asian Earth Sciences, vol. 18, no. 6, pp. 675-690, 2000.

[17] J.-W. Zi, P. A. Cawood, W.-M. Fan, Y.-J. Wang, and E. Tohver, "Contrasting rift and subduction-related plagiogranites in the Jinshajiang ophiolitic mélange, southwest China, and implications for the Paleo-Tethys," Tectonics, vol. 31, no. 2, pp. 1-18, 2012.

[18] P. Jian, D. Liu, A. Kröner et al., "Devonian to Permian plate tectonic cycle of the Paleo-Tethys Orogen in Southwest China (II): insights from zircon ages of ophiolites, arc/back-arc assemblages and within-plate igneous rocks and generation of the Emeishan CFB province," Lithos, vol. 113, no. 3-4, pp. 767-784, 2009. 
[19] P. Jian, D. Liu, and X. Sun, "SHRIMP dating of the PermoCarboniferous Jinshajiang ophiolite, southwestern China: geochronological constraints for the evolution of Paleo-Tethys," Journal of Asian Earth Sciences, vol. 32, no. 5-6, pp. 371-384, 2008.

[20] J. W. Zi, P. A. Cawood, W. M. Fan et al., "Triassic collision in the Paleo-Tethys Ocean constrained by volcanic activity in SW China," Lithos, vol. 144-145, pp. 145-160, 2012.

[21] J. W. Zi, P. A. Cawood, W. M. Fan, E. Tohver, Y. J. Wang, and T. C. McCuaig, "Generation of Early Indosinian enriched mantle-derived granitoid pluton in the Sanjiang Orogen (SW China) in response to closure of the Paleo-Tethys," Lithos, vol. 140-141, pp. 166-182, 2012.

[22] M. G. Zhan, Y. F. Lu, and S. F. Chen, Yangla Copper Deposits of Western Yunnan Province, China University of Geosciences Press, Wuhan, China, 1998.

[23] B. Li, G. F. Zou, S. M. Wen et al., "Fault structure, orecontrolling structural model and prospecting prediction of Yangla copper deposit, northwestern Yunnan," Mineral Exploration, vol. 5, no. 5, pp. 699-711, 2014.

[24] Y. F. Lu, M. G. Zhan, and K. X. Chen, "U-Pb isotopic dating of basalt from the Gajinxueshan Group in the Jinshajiang tectonic belt," Regional Geology of China, vol. 19, no. 2, pp. 155-158, 2000.

[25] J. J. Zhu, The Geological Setting and Metallogenesis of the Yangla Copper Deposit, SW Yunnan, Institure of Geochemistry, Chinese Academy of Sciences, Guiyang, China, 2012.

[26] J. Zhu, P. S. Zeng, L. C. Zeng, and J. Yin, "Stratigraphic subdivision of the Yangla copper ore districtu, northwestern Yunnan," Acta Geologica Sinica, vol. 83, no. 10, pp. 14151420, 2009.

[27] X. A. Yang, J. J. Liu, and S. Y. Han, "U-Pb dating of zircon from the Linong granodiorite, Re-Os dating of molybdenite from the ore body and their geological significances in the Yangla copper deposit, Yunnan," Acta Petrologica Sinica, vol. 27, no. 9, pp. 2567-2576, 2011.

[28] X. Y. Meng, The Petrogenesis of the Skarn and the Magmatic Origin in the Yangla Copper Deposit Area along Jinshajiang Belt, China University of Geosciences, Beijing, China, Western Yunnan Province, 2016.

[29] J. Q. Wei, M. G. Zhan, Y. F. Lu, K. X. Chen, and L. Q. He, "Geochemistry of granitoids in Yangla ore district, western Yunnan," Geology and Mineral Resources of South China, vol. 4, pp. 50-56, 1997.

[30] R. Gao, L. Xiao, Q. He, J. Yuan, P. Z. Ni, and J. X. Du, “Geochronology, geochemistry and petrogenesis of granites in Weixi Deqin, West Yunnan," Earth Science-Journal of China University of Geosciences, vol. 35, no. 2, pp. 186-200, 2010.

[31] K. X. Chen, J. Q. Wei, and D. P. Yan, “A preliminary study of porphyry bodies and related mineralization in Yangla area, Deqing, western Yunnan," Geology and Mineral Resources of South China, vol. 2, pp. 1-8, 1999.

[32] P. S. Zeng, Y. B. Wang, Q. Ma, Z. Q. Wang, and L. G. Wen, "Diachronous collision-closure of the Jinshajiang paleoocean basin in the Yangla area: constraints from ages of the granites," Earth Science Frontiers, vol. 25, no. 6, pp. 092-105, 2018.

[33] P. S. Zeng, G. H. Yin, and W. C. Li, Tectonic-Magmatic-Metallogenic System of Deqin-Yangla Ore Concentration Area within the Jingshajiang Orogeny, Geological Publishing House, Beijing, China, 2015.
[34] X. A. Yang, J. J. Liu, D. P. Li et al., "Zircon U-Pb dating and geochemistry of the Linong granitoid and its relationship to $\mathrm{Cu}$ mineralization in the Yangla copper deposit, Yunnan, China," Resource Geology, 2013, vol. 63, no. 2, pp. 224-238, 2013.

[35] X. A. Yang, Superimposed Mineralization and Prospecting Patterns of the Yangla Mineralization Zone in Western Yunnan Province, China University of Geosciences, Beijing, China, 2012.

[36] X. A. Yang, J. J. Liu, S. Y. Han et al., "Mineral composition, geochemistry of the Yangla copper deposit in Yunnan and their geological significances," Geoscience, vol. 26, no. 2, pp. 229-242, 2012.

[37] X. Y. Meng, J. W. Mao, C. Q. Zhang, D. Y. Zhang, Z. G. Kong, and F. D. Jia, "The timing, origin and T-fO2 crystallization conditions of longlived magmatism at the Yangla copper deposit, Sanjiang Tethyan orogenic belt: implications for post-collisional magmatic-hydrothermal ore formation," Gondwana Research, vol. 40, pp. 21-229, 2016.

[38] T. Andersen, "Correction of common lead in U-Pb analyses that do not report ${ }^{204} \mathrm{~Pb}$," Chemical Geology, vol. 192, no. 12, pp. 59-79, 2002.

[39] K. R. Ludwing, "User's manual for Isoplot 3.75: a geochronological toolkit for Microsoft Excel," in Berkeley Geochronology Center Special Publication No.5, 2012.

[40] L. P. Black, S. L. Kamo, C. M. Allen et al., "Improved ${ }^{206} \mathrm{~Pb} /{ }^{238} \mathrm{U}$ microprobe geochronology by the monitoring of a trace-element-related matrix effect; SHRIMP, ID-TIMS, ELA-ICP-MS and oxygen isotope documentation for a series of zircon standards," Chemical Geology, vol. 205, no. 1-2, pp. 115-140, 2004.

[41] L. Qi, J. Hu, and D. C. Gregoire, "Determination of trace elements in grantes by inductively coupled plasma mass spectrometry," Talanta, vol. 51, no. 3, pp. 507-513, 2000.

[42] Y. B. Wu, Y. F. Zheng, B. Gong, J. Tang, Z. F. Zhao, and X. P. $\mathrm{Zha}$, "Zircon $\mathrm{U}-\mathrm{Pb}$ ages and oxygen isotope compositions of the Luzhenguan magmatic complex in the Beihuaiyang zone," Acta Petrologica Sinica, vol. 20, no. 5, pp. 1007-1024, 2004.

[43] I. Williams and S. Laesson, "Isotopic evidence for the Precambrian provenance and Caledonian metamorphism of high grade paragneisses from the Seve Nappes, Scandinavian Caledonides," Contributions to Mineralogy and Petrology, vol. 7, no. 2, pp. 205-217, 1987.

[44] C. Wei, L. Ye, Z. L. Huang et al., "Ore genesis and geodynamic setting of Laochang Ag- $\mathrm{Pb}-\mathrm{Zn}-\mathrm{Cu}$ deposit, Southern Sanjiang Tethys Metallogenic Belt, China: constraints from whole rock geochemistry, trace elements in sphalerite, zircon $\mathrm{U}-\mathrm{Pb}$ dating and $\mathrm{Pb}$ isotopes," Minerals, vol. 8, pp. 1-29, 2018.

[45] X. Wei, Y. G. Xu, B. He, L. Zhang, X. P. Xia, and X. F. Shi, "Zircon $\mathrm{U}-\mathrm{Pb}$ age and $\mathrm{Hf}-\mathrm{O}$ isotope insights into genesis of Permian Tarim felsic rocks, NW China: implications for crustal melting in response to a mantle plume," Gondwana Research, vol. 76, pp. 290-302, 2019.

[46] Y. Wang, X. Ma, X. Qu, and W. Chen, "Geochronology and petrogenesis of the Xiongmei Cu-bearing granodiorite porphyry in North Lhasa subterrane, Central Tibet: implication for the evolution of Bangong-Nujiang metallogenic belt," Ore Geology Reviews, vol. 114, p. 103119, 2019.

[47] Z. M. Yang, Z. Q. Hou, N. C. White, Z. S. Chang, Z. Q. Li, and Y. C. Song, "Geology of the post-collisional porphyry coppermolybdenum deposit at Qulong, Tibet," Ore Geology Reviews, vol. 36, no. 1-3, pp. 133-159, 2009. 
[48] W. B. Zheng, J. X. Tang, K. H. Zhong et al., "Geology of the Jiama porphyry copper-polymetallic system, Lhasa Region, China," Ore Geology Reviews, vol. 74, pp. 151-169, 2016.

[49] H. Y. Chen and C. Wu, "Metallogenesis and major challenges of porphyry copper systems above subduction zones," Science China Earth Sciences, vol. 63, no. 7, pp. 899-918, 2020.

[50] D. R. Cooke, M. Baker, P. Hollings et al., "New advances in detecting the distal geochemical footprints of porphyry systems-Epidote mineral chemistry as a tool for vectoring and fertility assessments," Soc Econ Geol Spec Publ, vol. 18, pp. 1-27, 2014.

[51] R. H. Sillitoe, "Porphyry copper systems," Economic Geology, vol. 105, no. 1, pp. 3-41, 2010.

[52] X. F. Wang, B. Li, S. J. Guan, O. Nadeau, and G. Tang, "Mineralized granitic porphyry of the Yangla copper deposit, Western Yunnan, China: geochemistry of fluid inclusions and $\mathrm{H}-\mathrm{O}, \mathrm{S}$, and $\mathrm{Pb}$ isotopes," Geofluids, vol. 2020, Article ID 4391703, 32 pages, 2020.

[53] J. X. Zhou, Geochemistry and Petrogenesis of Igneous Rocks Containing Amphibole and Mica: A Case Study of Plate Collision Involving Scotland and Himalayas, Science Press, Beijing, China, 1999.

[54] A. R. Hastie, A. C. Kerr, J. A. Pearce, and S. F. Mitchell, "Classification of altered volcanic island arc rocks using immobile trace elements: development of the Th-Co discrimination diagram," Journal of Petrology, vol. 48, no. 12, pp. 2341-2357, 2007.

[55] R. E. Smith and S. E. Smith, "Comments on the use of Ti, $\mathrm{Zr}, \mathrm{Y}, \mathrm{Sr}, \mathrm{K}, \mathrm{P}$ and $\mathrm{Nb}$ in classification of basaltic magmas," Earth and Planetary Science Letters, vol. 32, no. 2, pp. 114120, 1976.

[56] W. Ma, Y. Liu, Z. Yang, Z. Li, X. Zhao, and F. Fei, “Alteration, mineralization, and genesis of the Lietinggang-Leqingla $\mathrm{Pb}-$ $\mathrm{Zn}-\mathrm{Fe}-\mathrm{Cu}-\mathrm{Mo}$ skarn deposit, Tibet, China," Ore Geology Reviews, vol. 90, pp. 897-912, 2017.

[57] S. R. Hart, A. J. Erlank, and E. J. D. Kable, "Sea floor basalt alteration: some chemical and Sr isotopic effects," Contrib. Miner. Petrol., vol. 44, no. 3, pp. 219-230, 1974.

[58] F. Y. Wu, X. H. Li, J. H. Yang, and Y. F. Zheng, "Discussions on the petrogenesis of granites," Acta Petrologica Sinica, 2007, vol. 23, no. 6, pp. 1217-1238, 2007.

[59] H. F. Lan, H. Z. Wang, H. F. Ling, W. F. Chen, K. X. Wang, and D. Wang, "Petrogenesis of the Chashan granite in the northern Guangdong Province and its implication for the metallogenic potential of tungsten and uranium mineralization," Acta Geologica Sinica, vol. 94, no. 4, pp. 1143-1165, 2020.

[60] X.-H. Li, Z.-X. Li, W.-X. Li et al., "U-Pb zircon, geochemical and Sr-Nd-Hf isotopic constraints on age and origin of Jurassic I- and A-type granites from Central Guangdong, SE China: a major igneous event in response to foundering of a subducted flat-slab?," Lithos, 2007, vol. 96, no. 1-2, pp. 186-204, 2007.

[61] S. Liu, R. Z. Hu, S. Gao et al., "U-Pb zircon, geochemical and Sr-Nd-Hf isotopic constraints on the age and origin of Early Palaeozoic I-type granite from the Tengchong-Baoshan block, Western Yunnan Province, SW China," Journal of Asian Earth Sciences, vol. 36, no. 2-3, pp. 168-182, 2009.

[62] Q. R. Wei, S. Zhao, J. Wang et al., "Petrogenesis of the monzonitic granite of the Qinmalong District, Nanmulin County, Tibet, China," Earth Science Fronties, vol. 25, no. 6, pp. 136151, 2018.
[63] F. Y. Wu, B. M. Jahn, S. A. Wilde et al., "Highly fractionated Itype granites in NE China (I): geochronology and petrogenesis," Lithos, vol. 66, no. 3-4, pp. 241-273, 2003.

[64] A. J. R. White, "Sources of granite magmas," Geological Society of America Abstract with Programs, vol. 11, p. 539, 1979.

[65] P. Jian, D. Y. Liu, and X. M. Sun, "SHRIMP dating of carboniferous Jinshajiang ophiolite in western Yunnan and Sichuan: geochronological constraints on the evolution of the PaleoTethys oceanic crust," Acta Geologica Sinica, 2003a, vol. 77, no. 2, pp. 217-228, 2003.

[66] P. Jian, D. Y. Liu, and X. M. Sun, "SHRIMP dating of Baimaxueshan and Ludian granitoid batholiths, Northwest Yunnan Province, and its geological implications," Acta Geoscientia Sinica, vol. 24, no. 4, pp. 337-342, 2003.

[67] Q. W. Wang and K. M. Wang, Granite and Metallogenic Series in Western Sichuan Province, Geological Publishing House, Beijing, China, 2008.

[68] T. P. Peng, Y. J. Wang, W. M. Fan, D. Y. Liu, Y. R. Shi, and L. C. Miao, "Early Mesozoic acidic volcanic rocks from the southern Lancangjiang zone: zircon SHRIMP U-Pb geochronology and tectonic implications," Science in China Series D: Earth Sciences, vol. 39, pp. 123-132, 2006.

[69] R. Altherr, A. Holl, E. Hegner, C. Langer, and H. Kreuzer, "High-potassium, calc-alkaline I-type plutonism in the European Variscides: northern Vosges (France) and northern Schwarzwald (Germany)," Lithos, vol. 50, no. 1-3, pp. 51-73, 2000.

[70] P. J. Sylvester, "Post-collisional strongly peraluminous granites," Lithos, vol. 45, no. 1-4, pp. 29-44, 1998.

[71] S. F. Lu, X. Q. Zhu, and X. F. Li, "Geochronology and geochemistry of the five magmatic rocks in the Ningzhen region, China," Acta Geochemical, vol. 38, no. 2, pp. 241-261, 2019.

[72] G. Peressini, J. E. Quick, S. Sinigoi, A. W. Hofmann, and M. Fanning, "Duration of a large mafic intrusion and heat transfer in the lower crust: a SHRIMP U-Pb zircon study in the Ivrea-Verbano zone (Western Alps, Italy)," Journal of Petrology, vol. 48, no. 6, pp. 1185-1218, 2007.

[73] E. A. K. Middlemost, "Naming materials in the magma/igneous rock system," Earth Science Reviews, vol. 37, no. 3-4, pp. 215-224, 1994.

[74] G. W. Morrison, "Characteristics and tectonic setting of the shoshonite rock association," Lithos, vol. 13, no. 1, pp. 97108, 1980.

[75] P. C. Rickwood, "Boundary lines within petrologic diagrams which use oxides of major and minor elements," Lithos, vol. 22, no. 4, pp. 247-263, 1989.

[76] H. R. Rollinson, "Using geochemical data: evaluation, presentation, interpretation," New York: Longman Scientific and Technical, vol. 58, no. 392, pp. 523-523, 1993.

[77] J. B. Wright, "A simple alkalinity ratio and its application to questions of non-orogenic granite genesis," Geological Magazine, vol. 106, no. 4, pp. 370-384, 1969.

[78] P. D. Maniar and P. M. Piccoli, "Tectonic discrimination of granitoids," Geological Society of America Bulletin, vol. 101, no. 5, pp. 635-643, 1989.

[79] S. S. Sun and W. F. Mcdonough, "Chemical and isotopic systematics of oceanic basalts: implications for mantle composition and processes," Geological Society Special Publication, vol. 42, no. 1, pp. 313-345, 1989.

[80] J. B. Whalen, K. L. Currie, and B. W. Chappell, "A-type granites: geochemical characteristics, discrimination and 
petrogenesis," Contribution to Mineralogy and Petrology, vol. 95, no. 4, pp. 407-419, 1987.

[81] J. A. Pearce, S. J. Lippard, and S. Roberts, "Characteristics and tectonic significance of supra-subduction zone ophiolites," Geological Society London Special Publications, vol. 16, no. 1, pp. 77-94, 1984.

[82] P. Douce, "Amphibolite to granulite transition in aluminous greywackes from the Sierra de Comechingones, Cordoba, Argentina," Journal of Metamorphic Geology, vol. 17, no. 4, pp. 415-434, 1999.

[83] V. Janoušek, F. Finger, M. Roberts, J. Frýda, C. Pin, and D. Dolejš, "Deciphering the petrogenesis of deeply buried granites: whole-rock geochemical constraints on the origin of largely undepleted felsic granulites from the Moldanubian zone of the Bohemian Massif," Transactions of the Royal Society of Edinburgh Earth Sciences, vol. 95, no. 1-2, pp. 141-159, 2004. 